\title{
THE JUDICIAL PURSUIT OF LOCAL FISCAL EQUITY
}

\section{Robert P. Inman ${ }^{*}$ and Daniel L. Rubinfeld**}

In recent years, some courts have attempted to reform local government financing by imposing expenditure, tax, assessment, and zoning reforms. In this Article, Professors Inman and Rubinfeld analyze the prospects for local fiscal equity such court-imposed mandates offer. Their economic analysis shows that substantial income variations coupled with the ability of families to relocate undercut attempts by courts to impose fiscal equity on local government. They conclude that only programs based on income redistribution or on centralized financing of local services will result in tax and spending equity, though such programs are beyond the power of courts to enact.

7 he local public sector through its decisions to tax and spend has substantial effects on the economic well-being of all Americans. Local governments currently provide over thirty percent of all nondefense government expenditures. ${ }^{x}$ To pay the bill they tax directly about five percent of their citizens' personal income. ${ }^{2}$ More important than the mere size of the local sector,

* Associate Professor of Finance and Economics, University of Pennsylvania.

** Associate Professor of Economics and Law and Research Associate, Institute of Public Policy Studies, University of Michigan.

When this research was begun, Professor Inman was the Robert Woods Johnson Foundation Visiting Faculty Fellow at Harvard University and Professor Rubinfeld was a Fellow at the National Bureau of Economic Research, Cambridge, Massachusetts. We would like to thank these sponsors for their financial support during the first stages of this project. Professor Inman received additional research support from the Rodney White Center for Financial Research for which he is grateful.

An earlier version of this Article was presented to the American Economic Association meetings in December, I977, and at seminars at the University of Pennsylvania, Princeton, and Yale. The comments of Richard Netzer, Bennett Harrison, and Richard Nelson were particularly helpful. In addition, several friends and colleagues have read earlier drafts of this work and have offered extended comments. Paul Dimond, Gregory Staple, Todd Franks, William Henn, Tom Palay, and Professors Robert Ellickson, Gerald Frug, Richard Lempert, and A. Mitchell Polinsky deserve special thanks.

We have attempted to present our findings with a minimal degree of technical jargon. Extended mathematical and technical discussions have, to the extent possible, been placed in footnotes.

${ }^{1}$ In 1975 , total expenditures on public services by city, county, and school district governments were $\$ 116.6$ billion; total expenditures by all governments for nondefense public services were $\$ 387.3$ billion. See BUREAU of the CENSUs, U.S. Dep't of Commerce, Statistical Abstract of the United States i29, 280, 298-300 (1977).

${ }^{2}$ Local taxes collected by city, county, and school district governments totalled $\$ 56.4$ billion in 1975 , while personal income amounted to $\$ 1057.2$ billion. See id. at 300,428 . 
however, are the services it provides - education, police and fire protection, health care, public transportation, museums, libraries, zoos, and parks. Urban governments to a large extent dictate the quality of life in urban America. Put simply, the impact of local fiscal decisions on our present and future lifestyle is immense.

Yet, the distribution of public services and taxes within the urban public economy reveals potentially significant inequities. The typical metropolitan area has a few communities with low crime rates, clean streets, green parks, and well-funded schools; most neighborhoods have sporadic crime, maintained streets, and schools financed at modest levels; finally, there are some communities where crime rates are high, housing is in disrepair, and schools are minimally financed. Further, taxes as a percentage of family income are often highest in communities with low to adequate levels of public services and lowest in areas with high services. $^{3}$

Legislative attempts to equalize the distribution of taxes and expenditures have had little impact on this pattern. ${ }^{4}$ Increasingly frustrated by the failure of these state and federal programs to achieve fairness, proponents of a more equitable urban economy have adopted a new strategy - judicially enforced equity. Zoning ordinances (the rules which directly affect where people live and in what sort of environment), tax laws (the rules which define who pays how much), and local spending decisions (which determine the pattern of benefits from local expenditures) are all undergoing close scrutiny by the courts. By restructuring the rules of local finance, the reformers hope to achieve increased equity by forcing a more equal distribution of local services and taxes.

This essay is a critical examination of the recent judicial attempt to achieve local fiscal reform. The analysis is premised upon the assumption that the reformers will win their legal bat-

${ }^{3}$ See R. Lineberry \& I. Sharkansky, Urban Politics and Public Poticy 28-32 (1974). See also pp. 1667-96 infra.

${ }^{4}$ Urban renewal, increased educational assistance, the federally sponsored "War on Poverty" (including the Model Cities program), and revenue sharing have only marginally affected the distribution of public dollars within the local economy. See, e.g., R. Nathan, A. Manvel \& S. Calkins, Monitoring Revenue Sharing (I975); R. Reischauer, General Revenue-Sharing-The Program's Incentives, in Financing the New Federalism 40 (W. Oates ed. 1975); J. Rothendeerg, Economic Evaluation of URban Renewal 223-29 (I967). See also note 34 infra. In addition, the Johnson Administration's War on Poverty was largely dismantled during the Nixon years in favor of more general assistance to the cities. 
tles. $^{5}$ We shall leave the task of charting the legal arguments to the legal scholars, and certainly much work has already been done in this regard. ${ }^{6}$ As our part of the division of labor, we limit our analysis to predicting the potential fiscal impact of possible judicial interventions. Two primary questions concern us. First, will the current judicial drive for fiscal equity lead to a more even distribution of local public services and taxes? Second, can one identify those judicial strategies which, either individually or in concert, are likely to be most effective in improving fiscal equity in the local public economy?

To begin the difficult task of answering these questions, it is first necessary to understand the present functioning of the decentralized metropolitan economy. This complex system of interactions among families, firms, and governments - each with their own objectives and resources - operates within the existing legal framework to create a predictable, although not inevitable, structure of fiscal outcomes. Part I describes the present allocation of services and taxes within a typical metropolitan economy. The observed distribution of spending and taxes is the result of a pattern of family locations within the urban economy in which the rich and middle class families reside primarily in the desirable high amenity suburbs, while poor families are concentrated in less attractive suburbs and in the central city. Importantly, this locational structure emerges from a legal framework granting broad discretion to local governments to tax wealth at the rates they select, to choose the level of services they will provide, and to zone for the type of esthetic and neighborhood quality they prefer. If the current situation is to be altered, one or more of the key determinants of this economic and legal environment must be changed.

'In fact, the ultimate victor of the raging legal battles has yet to emerge. See pp. I696-712 infra.

${ }^{6}$ See, e.g., Michelman, The Supreme Court, 1968 Term-Foreword: On Protecting the Poor Through the Fourteenth Amendment, 83 HaRv. L. REv. 7 (1969) (constitutional rights of indigents); Winter, Poverty, Economic Equality, and the Equal Protection Clause, I972 Sup. CT. Rev. $4 \mathrm{r}$ (same); J. Coons, W. Clune \& S. Sugaracan, Private Wealth and Public Education (1970) (school financing); Brest, Interdistrict Disparities in Educational Resources, 23 Stan. L. REv. 59r (r97r) (same); Schoettle, The Equal Protection Clause in Public Education, $7 \mathrm{r}$ ColUm. L. Rev. 1355 (197x) (same); Sager, Tight Little Islands: Exclusionary Zoning, Equal Protection, and the Indigent, 21 StaN. L. REv. 767 (1969) (zoning); Developments in the Law-Zoning, 9I HARv. L. Rev. 1624-708 (1978) (same) [hereinafter cited as Developments]; Fessler \& Haar, Beyond the Wrong Side of the Tracks: Municipal Services in the Interstices of Procedure, 6 HARv. C.R.-C.L. L. Rev. 44I (I97I) (access to public services); Goodman, De Facto School Segregation: A Constitutional and Empirical Analysis, 60 CaLIF. L. Rev. 275 (r972) (same). 
Part II canvasses the recent judicial attempts to improve local fiscal equity through the imposition of court-enforced restrictions on local fiscal and zoning choices. While federal constitutional law remains a largely ineffective tool in limiting local fiscal autonomy, certain state law developments offer greater promise. ${ }^{7}$ Yet, the economic effects of these substantive legal changes are uncertain; if the rules are changed, the equity performance of the local economy may or may not improve. Part III attempts to determine whether improvement is likely, and concludes that even in their initial impact, the reforms under consideration fall short of bringing about major changes in the distribution of metropolitan fiscal resources. Judicial reforms, even assuming the most favorable conditions, cannot achieve a significantly progressive (pro-poor) local public sector; the best that can be hoped for is that the existing regressive (pro-rich) structure can be transformed into a system that is proportional (neutral).

Unfortunately, even these maximal gains of proportionality often envisioned by lawyers and courts as the "likely" outcomes - may disappear if the local economy is permitted to adjust to the new legal rules. The fluidity of the urban economy is considerable; there are strong economic forces at work which tend to undo, wholly or in part, the potential achievements of legal reform. Part IV considers these local reactions, and assesses how different legal reforms fare against these longrun adjustments. A key determinant is the effect of regional adjustments; improvements within one community may be totally undermined by the movement of households to other localities within the metropolis. We conclude that a suburban-based strategy requiring both tax base equality for the financing of local services and less restrictive zoning throughout a large region is more likely to equalize the distribution of taxes and services than a city-based strategy requiring intrajurisdictional tax and spending equity. This conclusion is valid for all areas except those metropolitan regions which are densely developed and have little land available for new low cost housing. In these regions, a judicial strategy aimed at increasing equity within the central city may be more successful. Part V summarizes our conclusions and suggests why the present judicial strategies are necessarily constrained in their impact on urban fiscal equity.

In the end, the equilibrium-equity gains resulting from any judicial strategy seem exceedingly modest; the rich will continue to receive more services and pay proportionally less in taxes than the poor. Yet, this hardly leads to the conclusion that ju-

${ }^{7}$ See pp. $1696-712$ infra. 
dicial reform is undesirable. Our predictions deal solely with the distribution of dollars measured against a norm of equity, yet fiscal equality is clearly not the only defensible judicial objective. Legal values include more than the distribution of dollars; human dignity and nonquantifiable concepts of fairness also inform legal theory. An answer to the question "what is optimal?" must rely on a broader analysis which goes beyond any specific norms of equity, beyond the standards of economic efficiency, and, indeed, beyond the discipline of economics. Our objectives are more modest. Our primary goal is to predict the likely economic consequences of fiscal reform in the hope that this first step will aid in the design of an attractive urban fiscal policy. A secondary purpose of this Article is to spur additional study and comment by lawyers and other economists. So far, the economic impact of local government law has not received much consideration, ${ }^{\circ}$ standing in marked contrast to the recent wave of economic analyses of tort ${ }^{10}$ and antitrust law. ${ }^{11}$ In part, this may reflect the difficulty of predicting behavior in a social system as complex as the local public economy. ${ }^{12}$ It is our hope that this piece will contribute to the creation of a body of literature which can be used to direct and inform not only judicial decisions, but legislative and private choices as well.

\footnotetext{
${ }^{8}$ See generally Tribe, Structural Dule Process, to Harv. C.R.-C.L. L. Rev. 269 (1975).

- Present work in the field tends to emphasize the efficiency costs associated with $\operatorname{tax}$ and service equalization. See, e.g., Rubinfeld, Judicial Approaches to Local Public Sector Equity: An Economic Analysis, in CURRENT ISSUES IN URBAN EcoNomICs 542 (P. Mieszkowski \& M. Straszheim eds. 1979); Lineberry, Mandating Urban Equality: The Distribution of Municipal Public Services, 53 TEx. L. REv. 26 (I974); Note, Equalization of Municipal Services: The Economics of Serrano and Shaw, 82 YALE L.J. 89 (1972). There has also been some discussion of the relationship between the economic goals of efficiency and equity and legal notions of fairness in the provision of local services. See, e.g., Michelman, Political Markets and Community Determination: Competing Judicial Models of Local Government Legitimacy, 53 IND. L.J. I45 (1977); Essays ON THE LAW AND Economics of Locat Governaments (D. Rubinfeld ed. forthcoming).

${ }^{10}$ See, e.g., G. Calabresi, The Costs of Accidents (i970); G. Catabresi \& P. Babbit, Tragic Chotces (1978).

${ }^{11}$ See, e.g., P. Areeda \& D. Turner, Antttrust Law (1978); R. Posner, Economic ANalysis of Law (1977).

${ }^{12}$ We appreciate this complexity more than ever, having completed our study. We should note that our analysis is based upon average data for all United States metropolitan areas, and hence our quantitative predictions cannot be exact or region-specific. Nonetheless, we expect that our conclusions will ordinarily prove correct and that our approach will be applicable in evaluating judicial and legislative decisions which affect specific metropolitan areas. Any assumptionsand their probable validity - have, we hope, been made explicit. We believe our results to be quite "robust"; none of our major conclusions changes significantly when substantially more complex behavior patterns are assumed.
} 


\section{The Provision of Local Services: The Status Quo}

Our understanding of the metropolitan public economy suggests that four conditions, three "economic" and one "legal," best explain the present distribution of public expenditures and taxes at the local level. The first economic condition is that family incomes vary substantially within the metropolitan economy; ${ }^{13}$ the second is that commercial and industrial property is located unevenly throughout the metropolitan area; ${ }^{14}$ the third is that households are free to live in any locality they desire provided they can afford to purchase or rent available housing and are not subject to racial or other forms of discrimination. These three conditions determine an initial distribution of families. The general pattern is familiar; upper income families live in high amenity, low density housing on the urban fringe, while lower income groups live nearer the urban core. ${ }^{15}$ The final condition, which describes the current set of legal rules governing local power, is that localities operate within essentially fixed borders ${ }^{16}$ and are afforded wide discretion with respect to matters of local

${ }^{13}$ For the year 1973 , the income distribution of families by location in United States metropolitan areas was as follows:

\begin{tabular}{|c|c|c|c|}
\hline $\begin{array}{l}\text { Income } \\
\text { Interval } \\
(\$)\end{array}$ & $\begin{array}{c}\text { Central } \\
\text { City } \\
\%\end{array}$ & $\begin{array}{c}\text { Suburbs } \\
\%\end{array}$ & $\begin{array}{c}\text { Metropolitan } \\
\text { Total } \\
\%\end{array}$ \\
\hline $0-5,000$ & 8.15 & 5.85 & I4.0 \\
\hline $5,000-12,000$ & 16.77 & I9.32 & 36.1 \\
\hline $12,000-15,000$ & 6.18 & 9.22 & 15.4 \\
\hline $15,000-25,000$ & 9.18 & 16.52 & 25.7 \\
\hline $25,000+$ & 3.03 & 5.77 & 8.8 \\
\hline Total & $43.3 x$ & 56.69 & 100.0 \\
\hline
\end{tabular}

Bureau of the Census, U.S. Dep't of Commerce, Statisticat Abstract of the UnTIED Statrs 385 (1974) (Table 623). These data are used later in this Article when we measure the equity performance of a typical metropolitan economy before and after judicial reform.

${ }^{14}$ Certain technological innovations have made suburbs attractive places for various types of manufacturing. Suburbs have also captured much of the recent retail shopping growth, although central cities remain the primary employment centers. See generally D. Birch, The Economic Future of City and SUburb 3-I5 (I970) (Committee for Economic Development Supplementary Paper No. 30); B. Harrison, Urban Economic Development 7-4I, I94-95 (1972); J. Kain, The Distribution and Movement of Jobs and Industry, in THE METropolitaN EntGMa I (J. Wilson ed. I967); E. MIIIs, Studies In the Structure of THE URBAN ECONOMY 22-29 (r972).

${ }^{15}$ See, e.g., A. Downs, Openning Up tHe Suburbs I87-92 (I973); U.S. NAT'L Comm'N on URban Problems, BUIIDING the AMERICAN City 56 (Ig6g).

${ }^{16}$ See generally F. Michelman \& T. Sandalow, Governament in Urban Areas 49r-70r (r970). 
finance ${ }^{17}$ and land use policy. ${ }^{18}$ Operating together, the four conditions create the potential for great disparities in the allocation of urban resources.

Against the background of these four conditions, we will examine the fiscal performance of our metropolitan economies. We will begin by developing a description of how and where families decide to locate within a metropolitan area. Second, we will consider the current distribution of spending and taxes in the metropolitan economy. Third, we will examine the forces which perpetuate this status quo distribution. Finally, we will develop

${ }^{17}$ Home rule charters generally give local governments broad discretion in fiscal affairs. See F. Michelman \& T. Sandalow, supra note 16, at 308-13. Moreover, the courts have given local governments free rein in fiscal matters by imposing rather toothless "public purpose" requirements. See New Jersey Mortgage Fin. Agency v. McCrane, 56 N.J. 414, 267 A.2d 24 ( 1970 ) ; Basehore v. Hampden Indus. Dev. Auth., 433 Pa. 40, 248 A.2d 2 I2 (1969).

Limits do exist, however. Local revenue-raising ability is restricted by state constitutional provisions requiring tax "uniformity." See U.S. ADVISORY CoMm'N on Intergovernmental Relations, Financing Schools and Property Tax Retief - A State Responstbitity 87 (1973). See also pp. r70I-05 infra. Frequently, limits are also imposed on the ability of local governments to borrow funds, although the effectiveness of these restraints is in doubt. See F. Micheriman \& T. SANDALOW, supra note 16 , at $44^{28-46}$.

More serious restrictions on local finance decisions may evolve from the present "taxpayers revolt." In California, for example, taxpayer dissatisfaction resulted in Proposition $\mathrm{r}_{3}$, see CaI. Const. art. $\mathrm{r}_{3} \mathrm{a}$, which limits property taxes in the state to $\mathrm{I} \%$ of $x 975-1976$ property value with a small, yearly reassessment allowed for inflation.

But even when state law does impose limits on the exercise of local power, communities frequently circumvent these restrictions. For example, although state law usually requires a locality to tax all property at the same rate, some communities, through variable property assessment, have been able to avoid this requirement. See, e.g., Berry \& Bednarz, A Hedonic Model of Prices and Assessments for Single-Family Homes: Does the Assessor Follow the Market or the Market Follow the Assessor?, 5I LAND Econ. 2I (1975); Oldman \& Aaron, Assessment-Sales Ratios Under the Boston Property Tax, 18 Nat'L Tax J. 36 (1965); Edelstein, The Equity of Real Estate Property Taxation: An Empirical Examination of Philadelphia (forthcoming in LAND EcoN.). Variations in assessment rates mean that the "effective" tax rate on property values differs from the "nominal" tax rate. For example, if property is assessed for tax purposes at $50 \%$ of market value, and if the locality's declared tax rate is $5 \%$ (that is, $\$ 50$ per $\$$ I000 of assessed valuation or 50 mills), then the effective rate of tax on market property values is $2.5 \%$. We will focus on the effective rate of taxation here.

${ }^{18}$ Since the Supreme Court's ruling in Village of Euclid v. Ambler Realty Co., 272 U.S. 365 ( 1926 ), the federal courts have given localities broad control over land use planning under the police power. See, e.g., Penn Central Transp. Co. v. New York City, 438 U.S. I04 (I978); Village of Belle Terre v. Boraas, 4 r6 U.S. I (1974). Until recently, state courts have also been loath to upset the zoning provisions of local communities. See generally Comment, A Sttrvey of the Judicial Responses to Exclusionary Zoning, 22 Sxracuse L. Rev. 537, 538-62 (197I). 
descriptive measures of expenditure and tax equality as a basis for comparing these status quo distributions with judicially enforced changes in the fiscal patterns.

\section{A. Family Location Within the Metropolitan Economy}

Given market prices and family income, each household would like to purchase a particular mix of housing services, public services, and other goods. A family deciding where to locate within a metropolitan area will search for a community that provides that bundle of municipal services and housing which most closely approximates its preferred package. If there are enough communities to accommodate all possible combinations of family incomes and tastes, the family's search will be successful. ${ }^{19}$

This model for locational decisions clearly suggests that families moving to the suburbs will choose to live in communities composed of families with similar tastes and incomes, and therefore similar demands for housing and municipal services. In fact, the available evidence supports this hypothesis. In general, suburbs are quite homogeneous; families tend to be well-sorted throughout metropolitan regions. ${ }^{20}$

A family's location decision is complicated whenever a primary source of revenue for local services is a tax on residential and commercial property. In such a case, the family will search for the community which provides the desired mix of housing and services at the lowest tax rate. Low tax rates are of course made possible by the presence of commercial property, because commercial enterprises generally pay more in taxes than they receive in services. ${ }^{21}$ High income families will tend to be most

${ }^{10}$ The model for a family's location decision described here originated with Tiebout, A Pure Theory of Local Public Expenditure, 64 J. PoL. Econ. 4I6 (x956). Tiebout's ideas have since been refined by the introduction of production technologies and property taxation into the analysis. See, e.g., Hamilton, Zoning and Property Taxation in a System of Local Governments, I2 URB. STUD. 205 (1975); McGuire, Group Segregation and Optimal Jurisdictions, 82 J. Por. ECON. Ir2 (r974).

${ }^{20}$ For detailed evidence on family sorting, see Pack \& Pack, Metropolitan Fragmentation and Suburban Homogeneity, I4 URB. STUD. I9I (I977). See generally A. Downs, supra note I5; U.S. NAT', COMM'N on URBAN Problems, supra note 15. Undoubtedly, some mixing does occur. For the purposes of this discussion, however, such mixing will be ignored. The fact that some lower income households do live in rich suburbs will qualify our conclusions but always in a direction favorable to our main results.

${ }^{22}$ See Ladd, Local Education Expenditures, Fiscal Capacity, and the Composition of the Property Tax Base, 28 NaT'L TAX J. I45, 152-53 (I975).

The relationship between the size of a community's tax base and its tax rate can be expressed mathematically: if $C(G)$ represents the total costs per family of providing service level $G$, and $B$ represents the community's tax base per family (including commercial property), then the community tax rate, $r$, will be chosen 
successful in this search, however, since they will be able to outbid low income families for property in the desirable high commercial tax base communities with relatively low tax rates. As a result, all other things (including services) being equal, high income families will tend to live in low tax rate, high commercial tax base communities; low income families will locate in high tax rate, low commercial tax base communities.

There is statistical support for the hypothesis that family income is correlated with the size of a suburban community's tax base. Evidence from the New York-New Jersey metropolitan area suggests that the rich are more likely to live in suburbs with high commercial tax bases. In that region, suburban communities with mean family incomes of $\$ 20,000$ have about twice as much commercial property as do communities with a mean family income of $\$ 10,000 .^{22}$

Since the empirical evidence suggests that the model for family location decisions described here yields reasonable predictions, it will be relied on throughout this Article. Specifically, we will assume that prior to judicial reform, most high income families will choose to reside in high amenity, high commercial tax base suburbs, where they can purchase their desired level of public services at relatively low tax rates. Most middle income families, who find themselves outbid by the rich for the most attractive suburban sites, will decide to locate in the lower tax base communities surrounding the central city. Lower income families, which find both the high tax base central city and the suburbs attractive, will usually prefer the central city since appropriate housing and employment opportunities are often unavailable in the suburbs. ${ }^{23}$ Some middle income and high income families may also decide to locate in the high tax base central city, however. ${ }^{24}$

so that $C(G)=r B$ or $r=C(G) / B$. Thus an increase in $B$ produces a decrease in $r$ for any constant level of services $(G)$.

${ }^{22}$ For the New Jersey and Long Isiand suburbs of New York City, using the data from Inman, Micro-Fiscal Planning in the Regional Economy: A General Equilibrium Approach, 7 J. PUB. Econ. 237 (I977), we have found a simple linear relationship between the market value of commercial-industrial property per family $(M V C I)$ and mean family income $(I)$. Specifically, the relationship, was found to be $M V C I=2000+0.9 I$. It should be kept in mind that we are referring only to the suburbs here. The relationship between income and district wealth may be somewhat more complicated in the central cities. See generally Goldstein, Interdistrict Inequalities in School Financing: A Critical Analysis of Serrano v. Priest and its Progeny, I20 U. PA. L. REv. 504, 523-27 (1972); Note, A Statistical Analysis of the School Finance Decisions: On Winning Battles and Losing Wars, 81 YALE L.J. $\mathrm{r}_{3} 03, \mathrm{r}_{326-28}$ (1972).

${ }^{23}$ See p. 1667 supra.

${ }^{24}$ For more evidence suggesting that this description of family location within the metropolitan economy is accurate, see note 13 supra. 


\section{B. The Distribution of Taxes and Spending in the Metropolitan Economy}

Once a family has located within a particular community, it will be able to participate in decisions concerning the future level and distribution of local services and taxes. The outcome of these decisions will be a function of political forces within the community. In the suburbs, where the local population tends to be quite homogeneous, the taxing and spending levels set by the winning majority are likely to correspond closely to the preferred taxing and spending levels of all community residents. ${ }^{25}$ The situation in the diverse central city, composed of families of all income levels, is quite different. Preferred taxing and spending levels will vary substantially from family to family; a compromise must be struck between the high service demands of the rich and the relatively low demands of the poor. ${ }^{26}$

r. The Spending Pattern. - We will begin our discussion of spending patterns by examining variations in expenditures among suburban communities. As we have already argued, the suburban political process is likely to result in a spending level which closely approximates the preferred spending level of each community member. Thus, we can determine how spending will vary among suburban communities by examining differences in the preferred spending levels of individual families living within those communities.

The typical suburban family's demand for public services can be represented by a standard downward sloping demand curve. The demand curve associates the quantity of public services demanded by the family $(G$, measured in dollars along the horizontal axis) with the per unit "price" the family will have to pay to receive this quantity of services (denoted as $\pi$ and measured along the vertical axis). As the price $(\pi)$ for services declines,

${ }^{25}$ See, e.g., Governing Education: A Reader on Politics, Power, and Public ScHoor Policy (A. Rosenthal ed. I969) (case study demonstrating uniformity of decision in suburban school politics); Inman, Testing Political Economy's "As If" Proposition: Is the Median Income Voter Really Decisive? (I979) (forthcoming in PUB. C\#оICE). The political homogeneity of the suburban community in matters of land use policy has long been recognized. See, e.g., Ellickson, Suburban Growth Controls: An Economic and Legal Analysis, 86 YALE L.J. 385, 404-ro (r977) (characterizing suburban politics in terms of "homeowner cartels"); Note, The Constitutionality of Local Zoning, 79 YALE L.J. 896 (I970) (exclusionary local zoning decisions tend to become perpetual given homogeneous political structure); Note, Large Lot Zoning, 78 YALE L.J. I4I8 (I969) (homogeneous nature of suburban communities leads to economically inefficient decisions on lot size). See generally R. Linowes \& D. Allensworti, The Politics of Land UsE (1973).

${ }^{20}$ See generally E. Banfield \& J. WIIson, City Politics (I963); R. DaEr, WHo Governs? (I96I). 
the family's demand for local services $(G)$ increases. The solid line $g_{P} g_{P}$ in Figure 1 represents one possible demand curve for a typical family in a suburb $P$.

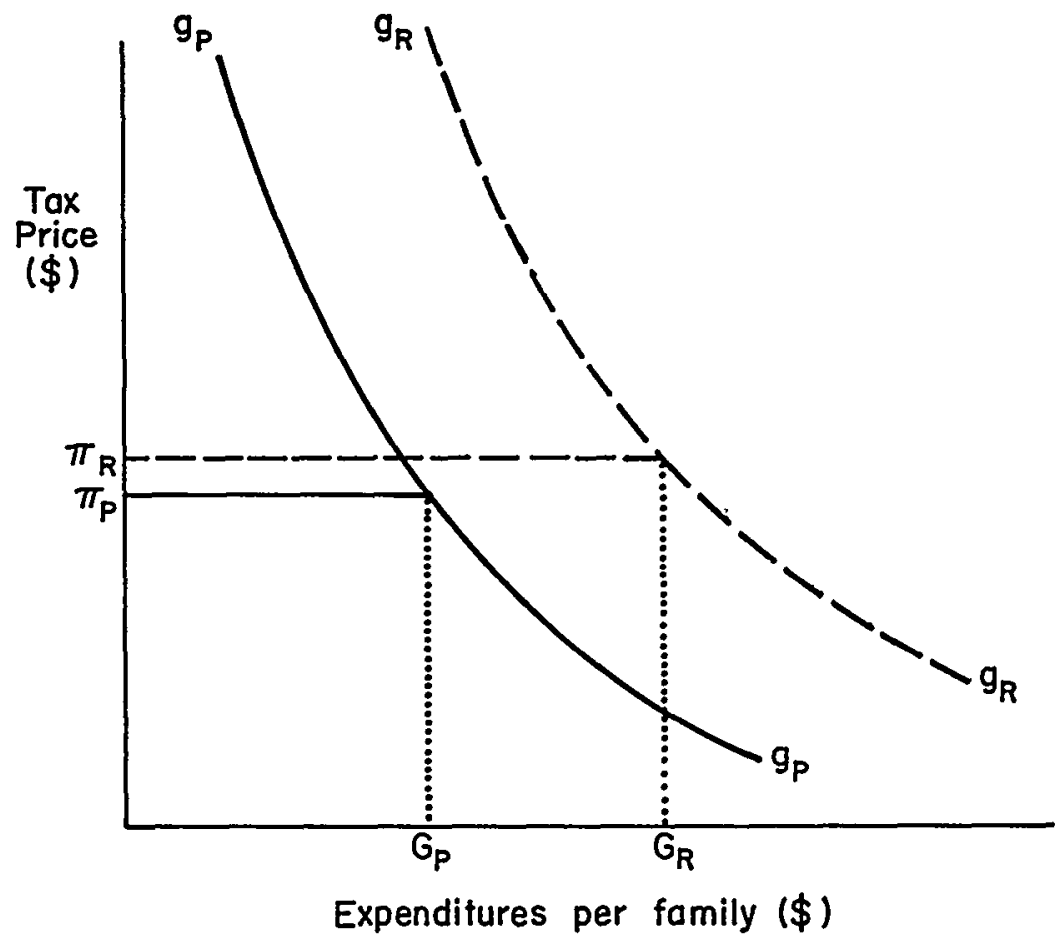

FIGURE 1

The price the family pays per unit of local services $(\pi)$ measures the tax costs to the family of having its locality supply an additional dollar of local services. For example, if a family paying $\$ \mathrm{I}, 000$ in taxes receives $\$ \mathrm{r}, 300$ in local services (with commercial property paying the extra $\$ 300$ ), then the family faces a "tax price" of $77 \%$ per dollar of local services received $(\pi=\$ \mathrm{I}, 000 / \$ \mathrm{I}, 300=0.77)$. That is, the tax price equals the family's tax bill divided by the dollar level of the public services received. The tax bill paid by each family is equal to the local tax rate multiplied by the assessed value of the family's property. Thus, to be more formal, if $r$ equals the community's tax rate and $b$ denotes the assessed value of the family property, the family's tax price can be written as $\pi=\operatorname{tax}$ bill $/ G=r b / G$. Expressing the family's tax price in this way dramatizes an important fact; since, as we have seen, ${ }^{27}$ low tax rates are correlated 
with large aggregate tax bases, then, ceteris paribus, families in communities with a large tax base will face lower tax prices.

The relationship between tax prices and tax bases can be demonstrated in a more direct way. Since communities must balance their budgets, the local tax rate $(r)$ multiplied by the local community tax base per family $(B)$ must equal local spending per family $(G)$. This relationship can be expressesd by the equation $r B=G$, which can be rewritten as $r=G / B$. Substituting this expression for $r$ in $\pi=r b / G$, we see that $\pi=$ $b(G / B) / G$, which reduces to $\pi=b / B .^{28}$ That is, a family's average tax price for local services is simply the ratio of the family's own tax base $(b)$ to the community's average tax base per family $(B)$. If the amount of high value commercial property within a community increases, $B$ will rise, $b$ will remain constant, and the family's tax price $(\pi)$ will decrease.

A family's demand curve and tax price determine its preferred spending level - and thus, since suburbs are homogeneous, the actual per family spending level for the community as a whole. Specifically, if the curve $g_{P} g_{P}$ in Figure 1 represents the demand for local public services of a family living in suburb $P$, and if the tax price $\left(\pi_{\mathrm{P}}\right)$ faced by a resident of suburb $P$ is $b_{P} / B_{P}$, the family's preferred spending level and suburb $P$ 's actual per family spending level is represented by point $G_{P}$.

To show how actual spending levels per family vary as income varies, we will consider another suburb $R$, whose residents are richer than those of suburb $P$. Since rich families will generally desire more local services than poor families at any given tax price, ${ }^{29}$ the demand curve for a family in suburb $R$, represented by curve $g_{R} g_{R}$ in Figure 1, will lie further to the right than the demand curve for a family in suburb $P$. Were both families to face the same tax price, the richer family would clearly choose a higher level of public services. However, tax prices may differ, and determining how the tax price $\left(\pi_{R}\right)$ shifts is somewhat difficult. High income families generally buy more expensive

${ }^{28}$ This is an average price. If the tax cost of local services varied with the level of local spending (due to state tax relief, for example), then the marginal price would differ from the average. Note, in addition, we have chosen to simplify our model by not taking into account reductions in tax price which are brought about through the presence of state and federal matching grant programs. This simplification is not likely to be important for us because the matching rates for specific grant programs are constant across all jurisdictions in a metropolitan area and unaffected by the judicially motivated reforms considered here. The notion of the "tax-price" of services is described more fully in Rubinfeld, Voting in a Local School Election: A Micro Analysis, 59 Rev. Econ. \& Statistics 30 (I977).

${ }^{29}$ The evidence is reviewed in Inman, The Fiscal Performance of Local Governments: An Interpretative Review, in CURRENT Issues IN URBAN ECONOMICS 270 (P. Mieszkowski \& M. Straszheim eds. I979). 
homes. ${ }^{30}$ Thus, $b_{R}$ will be greater than $b_{P}$. On the other hand, high income families tend to reside in communities with larger aggregate tax bases than do low income families. ${ }^{31}$ Thus, it is likely that $B_{R}$ is also greater than $B_{P}$. Since the tax price $\left(\pi_{R}\right)$ equals $b_{R} / B_{R}, \pi_{R}$ may be higher or lower than $\pi_{P}$, depending on the relative size of the differences between $b_{R}$ and $b_{P}$, and $B_{R}$ and $B_{P}$. In fact, data for the "average" suburban metropolitan economy indicate that the tax faced by wealthy families is slightly higher than that faced by lower income suburban families $\left(\pi_{R}>\pi_{P}\right)$. The difference is trivial, however. ${ }^{32}$ Given that $\pi_{R}$ is only slightly higher than $\pi_{P}$ and that a rich family's demand is substantially larger than a poor family's demand at any price, expenditures per family in suburb $R$ can be represented by $G_{R}$, which is larger than $G_{P}$. The gap between $G_{R}$ and $G_{P}$ is significant; it leads us to conclude that families in higher income suburbs demand and receive more services than their counterparts in lower income suburbs. Analysis of data for a typical metropolitan economy clearly supports this result. ${ }^{33}$

${ }^{30}$ See note 39 infra.

${ }^{31}$ See p. 1670 \& note 22 supra.

${ }^{32}$ Most families buy or rent a dwelling valued at roughly 2.5 times their expected lifetime annual income $(I)$, so that $b=2.5 I$, see note 39 infra. In addition, families tend to locate in suburban communities in which the overall base per family $(B)$ is related to family income according to the following equation: $B=1300+3.085 I$, see note 38 infre. Thus, tax prices in the suburbs equal $2.5 I /(1300+3.085 I)$. Inserting values for $I$, it is easy to see that $\pi$ rises as income rises for suburban families, but that the increase is relatively small. For example, tax prices rise from about 0.75 for $\$ 5,000$ families to about 0.79 for $\$ 25,000$ suburban families.

If we were to assume that rich families deduct their local property taxes when paying state and federal income taxes and that low income families do not, tax prices would fall as income rises. Since our primary concern is the impact of legal (not tax) reform on the urban economy, our analysis does not account for the effect of property tax deductions. It is easy to see, however, that such deductions favor rich homeowners and will therefore make a regressive distribution of local taxes and expenditures even more inequitable. See generally S. SURREX, Pathways to Tax Reform (I973).

${ }^{33}$ To determine more precisely the relationship between suburban spending and family incomes it is necessary to specify the relationship between income, tax prices, and public service spending for suburban jurisdictions. A review of the evidence presented in Inman, supra note 29 , on suburban spending for public services suggests the following specification for an aggregate public service demand equation: $G=I .565 I^{0.07} \pi^{-0.6}$. The exponents on income $(0.67)$ and tax price $(-0.6)$ are the geometric weighted average of suburban income and price elasticities of demand for education, health, police and fire protection, and various environmental services. The exponents are to be interpreted as the income and price elasticities of demand for local services by suburban jurisdictions. For example, a Io\% rise in residents' tax price $(\pi)$ means a $6 \%$ fall in $G$, holding income constant.

Using this demand relationship and the relationship we have developed to 
In contrast to the largely homogeneous suburbs, the central city has families of varying tastes and income levels residing within its borders. As a result, the process by which public services are allocated is characterized by compromise rather than consensus. A balance must be struck between the high service demands of the rich and the relatively low service demands of the poor. The actual level of expenditures per family will not correspond to an individual household's preferred expenditure level.

The tradeoffs can be complex. There is no reason to expect that the rich will always receive more services than the poor. The available empirical evidence suggests, however, that expenditures for services which improve the environment-street repairs, sanitation, urban renewal, parks and recreation - will favor the rich. The city health care budget is decidedly pro-poor. Spending on police and fire protection has been estimated to be either equal between rich and poor, or, since it is property-related, favorable to the rich. Estimates of the distribution of central city educational dollars suggest that it is proportional in some cities, and regressive in others. ${ }^{34}$ For all local services combined, spending rises with family income. The best current evidence on central city spending suggests, for example, that families with $\$$ ro,000 yearly incomes receive, on average, $25 \%$ more in services than families with $\$ 5,000$ incomes, while a family with a $\$ 20,000$ yearly income receives an additional $25 \%$ more than the $\$ 10,000$ income family. ${ }^{35}$ It is important to recognize that the absolute

define $\pi$, see note 32 supra, plus an assumption of homogeneous community incomes, see note 20 supra, we can calculate $G$ for each of the major suburban income groups in our typical metropolitan economy. The results are as follows: $\$ 476$ per family for $\$ 5,000$ income suburbs, $\$ 7 \mathrm{I}_{4}$ per family for $\$ 10,000$ income suburbs, $\$ 913$ per family for $\$ 15,000$ income suburbs, $\$ 1,369$ per family for $\$ 20,000$ income suburbs, and $\$ 1,602$ per family for $\$ 25,000$ income suburbs. Thus, it would appear that public service spending does rise as income rises. Reasonable variations in the price and income elasticities do not alter this basic income-service relationship, and none of our conclusions regarding fiscal equity prove sensitive to such variations.

${ }^{34}$ See generally M. Katzman, The Political Economy of URBan Schools (r97I) (distribution of educational services); Summers \& Wolfe, Intradistrict Distribution of School Inputs to the Disadvantaged: Evidence for the Courts, II J. Hudan Resources 328 (I976) (same); F. Levy, Urban Outcomes: Schools, STREETS, AND LIBRARIES (I974) (distribution of various municipal services); Weicher, The Allocation of Police Protection by Income Class, 8 URB. STOD. 207 (197I) (police).

${ }^{35}$ On the basis of the studies listed in note 34 supra, we estimate that aggregate local services within the city are distributed as $G_{\imath}=\theta I_{\imath}^{0.25}$, where $G_{i}$ denotes the services received by city families in income group $I_{k}$, and where $\theta$ is a constant which depends on the total level of spending by the city on residential services. The exponent on income is the distributional elasticity of city services 
levels of central city spending will be sensitive to the same economic forces which affected suburban spending. As the levels of family income rise or as the commercial tax base grows, city spending is likely to increase for all income groups within the city. ${ }^{36}$

It is now possible to combine our descriptions of the suburbs and the central city to create an integrated account of the expenditure patterns for major local services within the metropolitan area. Table I (columns 2-4) summarizes the expenditure distribution for our typical metropolitan economy. The array of numbers presented there is quite important, since it will be used to test the effects of judicial intervention on spending patterns. Thus, a thorough description is in order. Central city families have been divided into five income classes. The homogeneous suburban communities have also been divided into five income classes. In both the suburbs and the central city, expenditures

with respect to resident incomes. A Io\% rise in family income means a $2.5 \%$ rise in received services. The elasticity of 0.25 is calculated as the geometric weighted average of individual service elasticities derived from the studies listed in note 34 supra. This distributional elasticity no doubt varies from city to city but a value of 0.25 is typical for cities for which we have data. We have not included federally funded welfare services in our calculation of the distributional elasticity because such services are now generally administered at the state or county level. To include such payments in "city services" would badly confuse federal with local equity performance. In this study, we wish to concentrate on locally funded, locally provided public services.

${ }^{36}$ To define the total level of city spending, we assume that elected city officials respond to the preferences of the majority rule voter. This voter is typically identified with the median (5oth percentile) position in the distribution of income. This central city voter has a demand for public services of the form $G_{m}=x .565$. $I_{m}{ }^{0.71} \pi_{m}{ }^{-0.6}$, where $G_{m}$ is the median income voter's demand for services, $I_{m}$ is the median income voter's income, and $\pi_{m}$ is the median income voter's tax price. The exponents on income and tax price, $0.7 \mathrm{I}$ and -0.6 respectively, are the weighted averages of the public service income and price elasticities for large United States cities calculated from the studies surveyed in Inman, supra note 29. Here also our conclusions regarding the effects of the new case law on urban fiscal equity are not sensitive to reasonable variations in these elasticities.

For our typical metropolitan economy, the median family income level within the city is $\$ 10,500$. The tax price for the family with $I_{m}=\$ 10,500$ is $\pi_{m}=0.52$ after allowing for assessment variations of residential property within the city, see note 42 infra. Substituting these values for $I_{m}$ and $\pi_{m}$ into the median voter's demand equation gives a $G_{m}$ value of $\$ 1,654$ per family. If the median voter is to receive $\$ 1,654$ and $G_{m}=\theta I_{m}{ }^{0.2 \pi}$, then we can easily solve for $\theta$ using the equation $\$ 1,654=\theta(\$ 10,500)^{0.25}$. Thus, $\theta=162$. We can now calculate the service levels for all income classes within the city from the relationship $G_{1}=$ I62 $I_{i}^{0.25}$. For the five income levels used in this study we estimate that the $\$ 5,000$ income family receives $\$ 1,356$ in services, that the $\$ 10,000$ income family receives $\$ 1,613$, that the $\$ 15,000$ income family receives $\$ 1,785$, that the $\$ 20,000$ income family receives $\$ 1,918$, and that the $\$ 25,000$ income family receives $\$ 2,021$ in public services. 
TABLE I

The Status Quo

\begin{tabular}{|c|c|c|c|c|c|c|}
\hline \multirow[b]{2}{*}{$\begin{array}{l}\text { Family } \\
\text { Income } \\
\text { (I) }\end{array}$} & \multicolumn{3}{|c|}{$\begin{array}{c}\text { Expenditure Distribution } \\
(\$ / \text { family })\end{array}$} & \multicolumn{3}{|c|}{$\begin{array}{c}\text { Tax Distribution } \\
(\$ / \text { family })^{*}\end{array}$} \\
\hline & $\begin{array}{l}\text { Within } \\
\text { City } \\
(2)\end{array}$ & $\begin{array}{c}\text { Within } \\
\text { Suburbs } \\
\text { (3) }\end{array}$ & $\begin{array}{l}\text { Regional } \\
\text { Average } \\
\text { - (4) }\end{array}$ & $\begin{array}{l}\text { Within } \\
\text { City } \\
(5)\end{array}$ & $\begin{array}{c}\text { Within } \\
\text { Suburbs } \\
\text { (6) }\end{array}$ & $\begin{array}{l}\text { Regional } \\
\text { Average } \\
\quad(7)\end{array}$ \\
\hline 5,000 & $I, 356$ & 476 & 986 & $393(0.078)$ & 975 (0.195) & $636(0.127)$ \\
\hline 10,000 & 1,613 & 7 I4 & $I, I 32$ & $708(0.07 \mathrm{I})$ & $I, 000(0.100)$ & $863(0.086)$ \\
\hline 15,000 & $I, 785$ & $9 I 3$ & 1,262 & $I, 000(0.067)$ & I, or3 $(0.067)$ & $I, 005(0.067)$ \\
\hline 20,000 & $I, 9 I 8$ & $I, 369$ & $x, 567$ & $I, 277(0.064)$ & $I, 050(0.053)$ & $\mathrm{I}, \mathrm{I} 3 \mathrm{I}(0.057)$ \\
\hline 25,000 & $2,02 I$ & $I, 602$ & $\mathrm{I}, 749$ & $I, 544(0.062)$ & $I, 03 I(0.04 I)$ & $\operatorname{I,2IO}(0.048)$ \\
\hline $\begin{array}{c}a \\
\text { (expenditure } \\
\text { elasticity) }\end{array}$ & 0.25 & 0.65 & 0.35 & & & \\
\hline (tax elastici & ity) & & & I.orI & I.100 & I.054 \\
\hline
\end{tabular}

* All tax calculations based on a common $\$ 1,300$ per family local public spending level. Tax rates against family income are within parentheses.

rise as income rises; thus, as the fourth column of Table I demonstrates, service expenditures rise with income over the entire region. ${ }^{37}$ Central city expenditures are higher than suburban expenditures over all income classes, because the city's high commercial tax base helps ensure relatively low tax prices. Spending in low income suburbs is lower than spending anywhere else in the metropolitan area. Expenditures for wealthy families living in the central city are higher than expenditures anywhere else in the region. The average spending level per family is $\$ I, 654$ per family in the central city, $\$ \mathrm{I}, 003$ in the suburbs, and $\$ \mathrm{I}, 300$ for the region as a whole.

2. The Taxing Pattern. - Any effort to analyze the distribution of tax burdens among communities is complicated by variations in the level of services provided; a simple comparison of family tax bills is uninformative. This analysis can be simplified, however, by determining how much families would have to pay in order to receive a prespecified, common amount of local services. It will be assumed that each community spends $\$ \mathrm{I}, 300$ per family, the average spending level in our typical metropolitan region. Then, tax burdens for the residents of each locality will

${ }^{37}$ The regional columns in Table $I$ are calculated as the weighted averages of the suburban and central city columns using the share of each income class in the suburbs and in the central city respectively as weights. The weights are calculated from data presented in note $\mathrm{I}_{3}$ supra. 
be estimated by determining the size of the locality's tax base and solving for the tax rate which will support expenditures of $\$ 1,300$ per family.

Suburban community tax burdens can be calculated directly from an estimate of the local tax rate $(r)$ needed to support $\$ 1,300$ in expenditures per family. If the value of the community's tax base per family is $B$, then $r=\$ \mathrm{r}, 300 / B$. This relationship may be further refined. In general, as we have already seen, $B$ will rise as family income rises. In fact, $B$ can be estimated by the relationship $B=\$ 1,300+3.085 I$, where $I$ represents the community's average family income ${ }^{38}$ - which, in the suburbs, is assumed to equal each family's actual income. Thus, substituting this expression for $B$ in $r=\$ \mathrm{I}, 300 / B$, we see that $r=\$ \mathrm{r}, 300 /$ $(\$ I, 300+3.085 I)$. The individual family's tax burden will equal $r$ multiplied by the assessed value of the family property $b$. The family's property tax base $b$ is generally estimated to be 2.5 times family income $(2.5 I) .^{39}$ Thus, a suburban family's tax payment is equal to $2.5 I[\$ I, 300 /(\mathrm{I}, 300+3.085 I)]$.

Using this relationship, we see, for example, that a family earning $\$$ ro,000 will live in a $\$ 25,000$ home. The suburban community, which is assumed to be composed of other families with

${ }^{38}$ The $\operatorname{tax}$ base per family $(B)$ in a community will be the sum of the value of taxable residential property per family plus taxable commercial property per family. Since families typically buy or rent homes 2.5 times their incomes, if $b$ denotes the value of a family's housing and $I$ its income, then $b$ equals $2.5 I$, see note 39 infra. Commercial property per family ( $M V C I$ ) within the suburbs is related to suburban incomes according to the estimated relationship $M V C I=$ $\$ 2,000+0.9 I$, see note 22 supra. However, not all commercial industrial property is taxable and available to support local residential services. Some of the tax revenues raised from firms must be allocated to support services which benefit only the commercial establishments. Further, if firms are taxed too heavily, they may leave the high tax jurisdictions for other locations. Recent empirical work suggests that on average about $65 \%$ of the commercial tax base can be taxed to pay for residential services, see Ladd, supra note 21 . (Ladd finds that the margin for exploitation varies from a high of 0.79 for commercial property to a low of 0.45 for industrial property. We have used a weighted average of Ladd's two estimates.) Thus, the "taxable" commercial base is equal to $0.65 \mathrm{MVCI}$. Summing our estimates of taxable residential $(b)$ and taxable commercial property $(0.65 M V C I)$ gives the relationship $B=2.5 I+0.65 M V C I$, or, since $M V C I=\$ 2,000+0.9 I$, see note 22 supra, $B=\$ 1,300+3.085 I$, for a suburban community with family income equal to $I$.

${ }^{39}$ See, e.g., deLeeuw, Schnare \& Struyk, Housing, in The Urban Predicament I25-27 (W. Gorham \& N. Glazer eds. 1976) (housing expense to income ratio for average household was 0.19 in 1970 , but much higher for certain subcategories). A similar relationship holds for renters as well. Renters typically allocate about $25 \%$ of family income to housing. Since the annual rent paid is equal to the rate of return (i) times the market value of the rental property $(b)$, rent $=i b$, or $b=$ rent $/ i$. Since rent equals $25 \%$ of income $(I), b=0.25 I / i$, and for $i=0 . x$, $b$ equals $2.5 I$. 
the same income characteristics, will have an average family tax base of $\$ 32,150$. Thus, in order to fund expenditures of $\$ I, 300$ per household, the family will face a tax rate approximately equal to 0.04 and pay a final tax bill of roughly $\$ I, 000$. This $\$ I, 000$ property tax bill represents $10 \%$ of the family's income. The $\$ 300$ gap between expenditures and residential taxes is filled by the tax on commercial property.

The tax burdens and tax rates for families in each of our five classes of suburban jurisdictions are summarized in Table I, column 6 . While the absolute tax burdens rise slightly with family income (the very rich pay $\$ 56$ more than the very poor), tax burdens as a percentage of income fall dramatically. The suburban poor must pay roughly $20 \%$ of their annual income to support expenditures of $\$ I, 300$ per family; the rich can buy the same level of services by giving up only $4 \%$ of their family income. Thus, in the suburbs, taxation is regressive against family income. ${ }^{40}$

The taxation structure within the income-diverse central city differs from the suburban pattern, although it remains regressive. The taxable base per family $(B)$ within the city is approximately $\$ 48,800$ for our typical metropolitan region..$^{41}$ To support $\$ I, 300$ per family in residential expenditures, the city's average tax rate on residential property must equal $0.026(=\$ \mathrm{I}, 300 / \$ 48,800)$. Unlike tax burdens in the suburbs, however, tax burdens in the central city cannot be calculated directly from this average rate,

${ }^{40}$ Implicit in this result and in the analysis which follows is the assumption that renters bear the full burden of the property tax on rental property. This assumption is frequently made, see, e.g., H. Aaron, Who Pays the Property TAx? 24-25 (I975), and is valid if the regional supply curve for rental housing is elastic, see Grieson, The Supply of Rental Housing, 63 Arr. Econ. Rev. 433 (1973); Revier, The Incidence of Intermetropolitan Differentials in Property Taxes on Rental Housing (forthcoming in NaT'L TAX J.). See also Musgrave, Is a Property Tax on Housing Regressive?, 64 AMr. Econ. Rev. 222 (I974). The "new view" of property tax incidence, which assigns the burden of the tax to owners of capital, does not apply here because we are analyzing the effects of tax reform within a small regional economy from which capital is fully mobile. On the "new view," see Mieszkowski, The Property Tax: An Excise Tax or a Profits Tax?, I J. Pub. Econ. 73 (1972).

${ }^{41}$ The city's mean family income is $\$ 12,700$, implying a mean residential tax base of $\$ 31,750$ per family (equals $2.5(\$ 12,700)$ ). In most central cities, residential property constitutes from $50 \%$ to $60 \%$ of the value of all property, the remaining value attributable to commercial-industrial property. See 2 BUREAU OF THE CENSUS, U.S. Dep'T of Commerce, Taxable Property Values 35-36 (I967). If we select $55 \%$ as residential property's share of all property value in our typical central city, then the market value of all property must equal $\$ 58,000$ per family (equals $\$ 31,75 \% / 0.55)$. The market value of nonresidential property is therefore $\$ 26,250$ per family, of which $65 \%$, see note 38 supra, is taxable for residential purposes. The effective tax base from which revenue can be raised is therefore $\$ 31,750+0.65(\$ 26,250)$ or approximately $\$ 48,800$ per family. 
since it does not apply equally to all residential property. Intracity assessment rates on residential property - which transcribe market values into taxable values - are not uniform across all property. ${ }^{42}$ In many central cities, residential properties of high income families are systematically assessed at a lower percentage of true market value than properties owned or rented by low income families. Thus, despite an initially equal tax rate, assessment practices will place a higher tax burden on low income families in overassessed dwellings and a lower burden on the wealthy residing in underassessed homes. Recent evidence suggests that assessment rates decrease at the rate of $15 \%$ for each roo\% rise in income. ${ }^{43}$ We have used this finding to compute tax burdens and tax rates for central city residents in each of the five income classes. The results are presented in Table I, column 5 ; they clearly demonstrate the regressivity of central city taxation. Because the suburban and central city tax structures are regressive, the overall tax structure for the metropolitan economy will also be regressive (see Table I, column 7).

The results in Table I, however, may overstate the true degree of regressivity. Until now, our analysis has not accounted for the fact that the relatively low tax rates enjoyed by residents of suburbs with large tax bases command a price. In a local public economy where each locality has unique taxing rights to the property within its borders, the only way a family can enjoy the advantages of a high tax base community is to buy a home in that community. As a result, the demand for housing will rise in localities with favorable tax bases. If the supply of housing is limited, as it is in most metropolitan areas, then the rising demand will cause the price of land to rise. Indeed in Section A, we argued that the rich would be more likely to locate in high tax base suburbs precisely because of their ability to outbid low and middle income families for properties. Thus, if a family wishes to locate in a high tax base community, it must pay a premium on residential land. In effect, this premium is the price paid to en-

${ }^{42}$ See Berry \& Bednarz, supra note 17 (city assessment patterns in Chicago); Edelstein, supra note I7 (city assessment patterns in Philadelphia).

${ }^{43}$ If $a$ denotes the rate of assessment, then $a=4.27^{-0.15}$ defines the pattern of assessment of residential property for our typical central city, see Berry \& Bednarz, supra note I7; Edelstein, supra note 17. The assessment rate varies from I.I8 ("overassessment") for property occupied by $\$ 5,000$ families to 0.92 ("underassessment") for property occupied by $\$ 25,000$ families.

A family's tax payment equals the city's nominal tax rate $(r)$ times the family's assessed property value $(a b)$. Thus, the tax payment equals $r\left(4.2 I^{-0.15}\right)$. (2.5I) since $b$ equals 2.5I. Because the nominal tax rate $(r)$ needed to support the common $\$ \mathrm{I}, 300$ per family budget is 0.026 , tax payments for residents within the central city will equal $0.28 I^{0.5}$. This formula was used to compute the tax levels reported in Table $\mathrm{I}$, column 5 . 
joy the tax savings flowing from large tax bases. It should therefore be included if we wish to determine the true cost of buying local services. ${ }^{44}$

We estimated land premiums and "net fiscal costs" - actual tax payments adjusted to account for land premiums by adding in the change in land values for both the central city and the suburbs - over each of the five income classes. Our calculations, presented in Table II, indicate that high income families now living in the wealthiest $(\$ 25,000)$ suburbs pay a land premium of approximately $\$ 704$ per year. ${ }^{45}$ When this annual "charge" for

${ }^{44}$ This approach, suggested by Mieszkowski, supra note 40 , is now generally accepted as the correct conceptual solution to the problem of measuring the distributional effects of differences in local property tax rates. See generally Courant, A General Equilibrium Model of Heterogeneous Local Property Taxes, 8 J. PuB. Econ. 3I3 (I977).

${ }^{45}$ The table below presents our best estimate of what might happen to suburban residential land values, measured as the price per acre, if the relative tax advantages of a high tax base are capitalized into the price of residential property.

\begin{tabular}{|c|c|c|c|c|c|}
\hline $\begin{array}{c}\text { Distance } \\
\text { from } \\
\text { Central City } \\
\text { (r) }\end{array}$ & $\begin{array}{c}\text { Suburban } \\
\text { Income } \\
\text { (2) }\end{array}$ & $\begin{array}{c}\text { Price Before } \\
\text { Local Finance } \\
\text { (3) }\end{array}$ & $\begin{array}{c}\text { Price After } \\
\text { Local Finance } \\
\text { (4) }\end{array}$ & $\begin{array}{l}\text { Avg. Plot } \\
\text { Size }(L) \\
\quad(5)\end{array}$ & $\begin{array}{c}\text { Change in } \\
\text { Land Costs } \\
(\text { o.I })\left(\triangle P_{L}\right)(L) \\
(6)\end{array}$ \\
\hline $0-I$ & $\$ 5,000$ & $\$ 8 I, 486 /$ acre & $\$ 47,214 /$ acre & 0.0529 acres & $-\$ 180 /$ plot \\
\hline $0-1$ & $\$ 10,000$ & & I4/acre & 0.0158 acres & $-\$ 36_{3} /$ plot \\
\hline & $\$ 15,000$ & $\$ 67,585 /$ acre & o3/acre & 0.1728 acres & $-\$ 427 /$ plot \\
\hline & $\$ 20,000$ & $\$ 24,903 / d$ & cre & 0.3136 acres & $+\$ 226 /$ plot \\
\hline Io $\mathrm{I}$ & $\$ 25,000$ & $\$ 9,463 /$ acre & $\$ 21,945 /$ acre & 0.5696 acres & $+\$ 704 /$ plot \\
\hline
\end{tabular}

The third column gives the price per acre when no tax base or expenditure disparities between communities are allowed-that is, when local services are financed and distributed by a metropolitan government. Land prices fall as distance from the central city increases. Since living on residential land farther from the city will involve larger annual commuting costs for most residents, such locations will be less attractive. With public services provided regionally, only the "private" factors of commuting costs and the demand for open space affect land prices. See generally E. Murs, supra note 14 . To determine the prices listed in column 3, we used data provided by Mills, see E. MIILs, supra note I4, at 109-27, documenting the inverse relationship between land prices and distance from major employment centers (called a land price gradient) in a model without variation in public service provision. Specifically, we utilized Mills' simulation results predicting the locational patterns of three income classes (a $\$ 4,800$ income class, based on Mills' $\$ 20$ per day wage class, a $\$ 6,000$ income class, based on Mills' $\$ 25$ per day wage class, and a $\$ 7,200$ income class, based on Mills' $\$ 28$ per day wage class), to infer statistically how land price gradients vary with family income. (For a discussion of the theory of household location, see Hochman \& Ofek, The Value of Time in Consumption and Residential Location in an Urban Setting, 67 AM. EcoN. REv. 996 (I977).) We assigned land price gradients to each of our five income classes and using this information determined family location by calculating which income class would make the highest bid for land at that location.

The calculation is somewhat complex because the slope of the land price 
the local tax base is added to their actual tax payments of $\$ \mathrm{r}, 03 \mathrm{I}$ per family, the net fiscal cost of a $\$ I, 300$ budget is $\$ I, 735$ per

gradient at each location varies with income. For example, the rich $(\$ 25,000$ income class) are the top bidders for the land at the suburban fringe. To obtain this land, they must offer a price greater than the value of that land in agricultural use and also greater than any other bids by families desiring to use the land for residential purposes. This bid was calculated to be $\$ 9,643$ per acre and we located all these families ten miles or further from the city center. Similarly, we located the $\$ 15,000$ to $\$ 25,000$ families (with average income of $\$ 20,000$ ) in the two to ten mile range (an average of six miles) with a land price of $\$ 24,963$ per acre. Finally, we placed those suburban families with $\$ 15,000$ incomes at a two mile radius with a bid of $\$ 67,585$ per acre, those with $\$ 10,000$ incomes at one mile with a bid of $\$ 8 \mathrm{I}, 486$ per acre, and those with incomes of $\$ 5,000$ in the zero to one mile range with bids of $\$ 8 \mathrm{r}, 486$ as well. Central city residents are estimated to pay $\$ 76,889$ per acre for their land, a result which follows directly from Mills' simulations. The fact that the central city price is approximately $\$ 4,600$ per acre less than the price of land in the zero to one mile suburban ring reflects the differential demand for suburban over central city living by low income households.

The fourth column is an estimate of the actual land price gradient when public services are locally financed and tax base and subsequent expenditure disparities are allowed. Land prices rise in the high income and commercially rich fringe suburbs and fall in the low income suburbs and in the central city, which has a relatively small tax base. Residents of rich suburbs pay a significant premium in higher land costs to capture the tax advantages of living where they do. In contrast, the residents of the fiscally poorer suburban communities demand a subsidy (in the form of a reduced price for residential land) to locate in their now relatively less attractive, low tax base locations.

The actual land price gradient represented in column 4 was calculated in three steps.

(I) Attributing $20 \%$ of home value to land, see Grieson, Property Taxes and Land Value, I J. URB. EcoN. 376 (I974), then if $P_{L}$ is the price of land, $L$ is the amount of land in acres per family, and $b$ is the value of the home $(=2.5 I), P_{L} L=0.2 b=0.2(2.5 I)$, or

$$
\text { (a) } P_{L}=0.5 I / L \text {. }
$$

(2) From R. Muth, Cirtes AND Housing 312 (xg69), we have the following relationship of suburban income $\left(I_{s u b}\right)$ to mean central city income $\left(I_{c o}\right)$ at a distance, $u$, from the central city:

$$
\text { (b) } I_{s u \delta}=(\mathrm{I}+0 . \mathrm{I} u) I_{e \mathrm{c}}
$$

where $I_{c c}=\$ 12,700$ for our typical central city.

(3) From Harrison \& Kain, Cumulative Urban Growth and Urban Density Functions, I J. URB. Econ. 6I (1974), we adopt a description for the density function of families per square mile $(D)$ :

$$
\text { (c) } D=5,000 e^{-0.25 u}
$$

where 5,000 is the density of families in the central city when $u$, the distance from the center, is equal to zero, and $e$ is the base of the natural logarithm system (approximately 2.71). See BUREAU of THE CeNSUS, U.S. Dep'T OF Comamerce, Statisticad Abstract of the United States 24-25 (x974) (Table 24).

Therefore, for each distance from the center we can estimate suburban income from (b) and suburban density from (c). Given density and family income at each 
year (see Table II, column 7). Residents of the $\$ 20,000$ income suburbs pay an added premium of $\$ 226$ per year. Residents of the relatively low tax base $\$$ I $5,000, \$ 10,000$, and $\$ 5,000$ income suburbs, pay a "negative" premium; thus, their net fiscal costs are below actual tax payments. For the central city as a whole, land premiums are negative. The aggregate decrease in land value is distributed across all the city's various income classes in accordance with each class's consumption of land. The biggest savings go to the rich, whose consumption of land is relatively high; the smallest annual savings go to families in the $\$ 5,000$ income class, who consume little land (see Table II, column 4$){ }^{46}$

location, we can solve for acres per family $(L=$ acres per family $=(1 / D)(640$ acres/sq. mile)). Finally, land use per family $(L)$ and family income plus relationship (a) allow us to solve for the price of land at each distance from the central city. The land price results appear in column 4 , while column 5 reports land use per family $(L)$ at each distance from the central city.

The added land costs per year due to fiscal advantages for suburban residents appear in column 6 and are calculated as the amortized value of the difference $\left(\triangle P_{L}\right)$ between the price per plot with local finance and the price per plot without local finance. (The rate of amortization is $10 \%$.) Thus, the change in land costs equals o.I $\times \triangle P_{L}$ (= column $4-$ column 3$) \times L$ (= plot size).

${ }^{46}$ The change in land costs for city residents with locally financed public services and the status quo distribution of tax base can be calculated in a manner analogous to our calculation of suburban land price changes, see note 45 supra. For city residents, the price per acre of residential land falls from $\$ 76,889$ per acre without local finance to $\$ 49,609$ per acre with local finance-a decline of $\$ 27,280$ per acre. This land price saving is shared across city income classes according to their purchases of land. The table below summarizes the results:

\begin{tabular}{|c|c|c|}
\hline $\begin{array}{c}\text { Center City } \\
\text { Income }\end{array}$ & Avg. Plot Size (L) & $\begin{array}{l}\text { Costs with Local Finance } \\
\quad(\text { o.I })\left(\triangle P_{L}\right)(L)\end{array}$ \\
\hline$\$ 5,000$ & 0.050 acres & $-\$ 137 /$ plot \\
\hline$\$ 10,000$ & 0.ror acres & $-\$ 275 /$ plot \\
\hline$\$ 15,000$ & 0.151 acres & $-\$ 412 /$ plot \\
\hline$\$ 20,000$ & 0.202 acres & $-\$ 550 /$ plot \\
\hline$\$ 25,000$ & $0.25^{2}$ acres & $-\$ 68 y /$ plot \\
\hline
\end{tabular}

We have not included in these calculations the change in city residential land prices which might arise because of intracity assessment variations. Lower assessments mean lower taxes per unit of local services and such favored property may be expected to command a premium in the city land market. But in contrast to tax base advantages which accrue to property within suburban communities, assessment advantages within the city accrue instead to people. In particular, as was suggested in notes 42 and 43 supra, the high income families are favored. Indeed, if the rich move from one house in the city to another, the assessment advantage, which was designed to hold them within the city, travels with them. See Wales \& Wiens, Capitalization of Residential Property Taxes: An Empirical Study, 56 Rev. Econ. \& Statistics 329 (1974) (land values in Vancouver, British Columbia, do not reflect assessment rate differentials). 
TABLE II

Net Fiscal Costs: The Status Quo

\begin{tabular}{|c|c|c|c|c|c|c|c|}
\hline $\begin{array}{c}\text { Family } \\
\text { Income }(\$)\end{array}$ & Withi & in City (\$ & (family) & Within & Suburbs & $(\$ / f a m i l y)$ & $\begin{array}{l}\text { Within Regional } \\
\text { Avg. (\$/family) }\end{array}$ \\
\hline (I) & $\begin{array}{c}\text { Tax } \\
\text { Payments } \\
\text { (2) }\end{array}$ & $\begin{array}{l}\text { Annual } \\
\text { Land } \\
\text { Premium } \\
\text { (3) }\end{array}$ & $\begin{array}{c}\text { Net Fiscal } \\
\text { Cost* } \\
\text { (4) }\end{array}$ & $\begin{array}{c}\text { Tax } \\
\text { Payments } \\
\text { (5) }\end{array}$ & $\begin{array}{l}\text { Annual } \\
\text { Land } \\
\text { Premium } \\
\text { (6) }\end{array}$ & $\begin{array}{c}\text { Net Fiscal } \\
\text { Cost* } \\
(7)\end{array}$ & $\begin{array}{c}\text { Net Fiscal } \\
\text { Cost* } \\
(8)\end{array}$ \\
\hline $\begin{array}{r}5,000 \\
10,000 \\
15,000 \\
20,000 \\
25,000\end{array}$ & $\begin{array}{r}393 \\
708 \\
1,000 \\
1,277 \\
1,544\end{array}$ & $\begin{array}{l}-137 \\
-275 \\
-412 \\
-550 \\
-687\end{array}$ & $\begin{array}{l}256(0.05 \mathrm{I}) \\
433(0.043) \\
588(0.039) \\
727(0.036) \\
857(0.034)\end{array}$ & $\begin{array}{r}975 \\
I, 000 \\
I, 0 I 3 \\
I, 050 \\
I, 03 I\end{array}$ & $\begin{array}{r}-180 \\
-363 \\
-427 \\
226 \\
704\end{array}$ & $\begin{array}{c}795(0.16) \\
637(0.064) \\
586(0.089) \\
1,276(0.064) \\
I, 735(0.069)\end{array}$ & $\begin{array}{r}482(0.096) \\
541(0.059) \\
587(0.039) \\
1,078(0.059) \\
1,428(0.057)\end{array}$ \\
\hline $\begin{array}{l}\operatorname{tax}^{\epsilon} \\
\text { elasticity) }\end{array}$ & & & I.OII & & & 1.06 & 1.027 \\
\hline
\end{tabular}

* Net fiscal costs as a percentage of family income are within parentheses.

After accounting for the impact of fiscally induced land price changes, it would appear that the tax burdens of poor and middle income families are somewhat lower than actual tax payments indicate. The overall effect of incorporating fiscally induced land price changes into our analysis is to reduce the effective burdens of local finance upon the low and middle classes. Table II, column 8 also reports net fiscal costs and an implicit tax rate for the metropolitan region as a whole. ${ }^{47}$ it can now be seen that the overall rate structure is slightly progressive across the upper income groups, but still strongly regressive for the $70 \%$ of the population with annual incomes between $\$ 0$ and $\$ 55,000$. The tax rate which must be paid by poor families to finance a given level of local services is nearly twice the rate paid by the wealthiest families. While the regressivity has been softened, the central fact remains: locally based property taxation is regressive within the metropolitan economy.

\section{Sustaining the Status Quo}

The system described above is not self-perpetuating, given the obvious incentive for fiscal losers to move to more attractive communities. Why then has the status quo apparently achieved stability? To answer this question, we must consider the non-

47 The figures presented in Table II, column 8 are weighted averages of the results for the suburbs and the central city. The weights were computed from data presented in note 13 supra. 
economic factors which affect family location decisions and, most importantly, the exclusionary effects of local zoning.

Two key groups, both clearly able to move to potentially more desirable fiscal locations, fail to relocate for noneconomic reasons. High income central city families could easily move to the wealthy suburbs on the metropolitan fringe where they would enjoy a sizeable reduction in taxes and, presumably, a municipal spending level closer to their preferred amount. On the other hand, the poor and the lower middle class living in the suburbs could relocate in the central city which, because of a higher tax base, offers families in the \$o-\$15,000 income range an attractive low tax, high spending fiscal package. Families in these two groups choose not to move. The reason is that they prefer the living style in the communities where they are presently located and thus are willing to accept the fiscal disadvantages that choice entails. ${ }^{48}$

If the stability of the status quo could be attributed solely to lifestyle preferences, there would be little cause for concern, since those harmed by fiscal inequity could easily move if they so desired. There exist a number of families, however, who fail to relocate in part because of exclusionary zoning policies. Specifically, zoning barriers can prevent low and middle income families who live in the central city or small tax base suburbs from moving into the wealthy suburban communities, where they could enjoy a low tax, high spending fiscal package and an attractive living environment.

The economic forces which give rise to exclusionary zoning are easily described. The residents of the high income suburbs have an incentive to protect their favorable tax base, since a large tax base per family means low tax rates for any chosen spending level. Admitting families into the community who purchase homes with a value below the community average will lower the tax base per family. Thus, if the community wishes to maintain current spending levels, it will be forced to raise tax rates. ${ }^{49}$ This

${ }^{48} C f$. C. Perda, Everything In Its Place (1977) (importance of status in determining metropolitan location). Of course, racial discrimination also affects housing choice, see J. KaIn \& J. Quigley, Housing Markets and RaclaI DisCRIMINATION (1975), as does proximity to employment opportunities, see Rubinfeld, Suburban Zoning: A General Equilibrium Analysis, x8 J. RegronaL Scr. 33 (1978).

${ }^{49}$ To be sure, the question of whether low income residents are desirable is more complex than this. On the one hand, if single family, high income households usually have many school-aged children, then the increased tax base may be more than counterbalanced by added demands on the educational system. On the other hand, if low income families live in high-rise apartments and have few children, the fiscal benefits may be significant. What is important, however, is that high income communities can restrict high density, low income housing development 
increase in tax rates will make the suburb less attractive to future residents and hence lower the resale value of the remaining residents' properties. While existing residents wish to exclude, private developers have a strong incentive to build high density housing for lower income families in these communities. They can offer an attractive price for a residential site within a rich community and then earn sizeable profits by subdividing the lot into many smaller plots and selling them to lower income families. Furthermore, current residents of the suburb planning to move to another region for nonfiscal reasons will have a strong incentive to sell to these high-bid developers. Thus, working through a developer, a "coalition" of low income familes can, in effect, pool their resources and outbid one high income family for a residential plot in the high tax base suburb. ${ }^{50}$

whenever it appears that such a development will have a negative fiscal impact. See generally M. Neutze, The Suburban Apartment Boom (I968); R. Schafer, The Suburbanization of Multifamey Housing (I974); G. Sterniteb, Housino Development and Municipal Costs (I974).

so It is possible to estimate what a small coalition of lower income families will pay for the privilege of living on a typical plot in a high tax base suburb by using the concept of "consumer surplus." See Willig, Consumer's Surpluts Without Apology, 66 AM. Econ. Rev. 589 (I976).

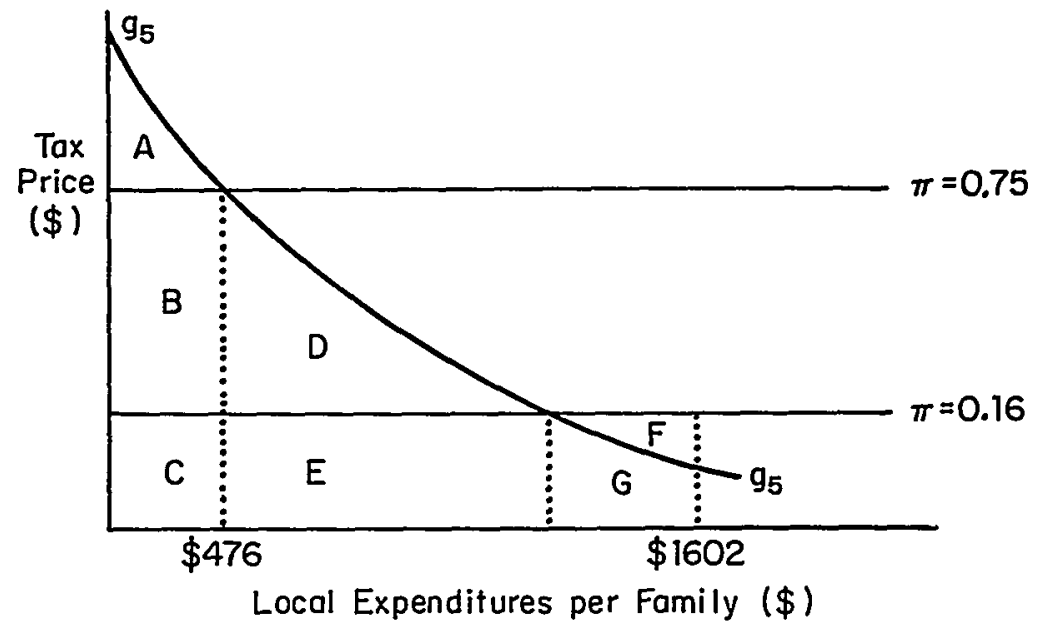

In the Figure above, $g_{s} g_{s}$ represents the demand curve for public services for a family with an annual income of $\$ 5,000$. When living in a $\$ 5,000$ suburb, this family faces a tax price for local services of $\pi=0.75$, see note 32 supra. In its $\$ 5,000$ suburb, the family prefers $G=\$ 476$ per family, see note 33 supra, the expenditure level at which the marginal cost of a unit of services just equals its willingness to pay for that extra unit (that is, when marginal costs equal marginal benefits). The family's total fiscal benefits from its current service package is the area under its demand curve $(A+B+C)$ while its total fiscal cost is the area under its marginal cost curve $(B+C)$. Net benefits or the fiscal consumer surplus from living in the $\$ 5,000$ suburb is area $A$. 
Of course, current residents are not powerless in this situation. They could pool their own resources and outbid the low income families for available property. If such a strategy were adopted, the existing residents would bear the costs of preserving the community's high tax base. A far more appealing alternative - since it shifts the burden to the nonresident low income families, developers, and resident families who would otherwise sell to low income families - is the enactment of exclusionary zoning controls. Such measures can take a number of different forms, including the imposition of minimum lot sizes and floor area requirements, and the prohibition of multifamily dwellings. Recently,

What would be the net fiscal surplus if this family lived in a $\$ 25,000$ suburb? First, we assume the family continues to spend 2.5 times its income on housing. Thus the $\$ 5,000$ family lives in a $\$ 12,500$ dwelling. The family therefore pays a lower tax price for local services of $\pi=\$ 12,500 / \$ 78,425=0.16(=b / B)$, where $\$ 78,425$ is the tax base per family in the $\$ 25,000$ suburb (for the procedure by which $B$ was computed, see note 38 supra). In addition, the $\$ 5,000$ family also enjoys more public services, since the $\$ 25,000$ suburb provides $\$ 1,602$ per family in public services. The total fiscal benefits are area $A+B+C+D+E+G$ and the total fiscal costs are $C+E+F+G$. The net fiscal gain when living in the $\$ 25,000$ community is therefore area $A+B+D-F$.

The benefit to a $\$ 5,000$ family of moving from its present suburb to a $\$ 25,000$ income suburb is the difference in the consumer surplus "earned" in the two communities, and equals the new surplus (area $A+B+D-F$ ) minus the old surplus (area $A$ ) or area $B+D-F$. We have estimated the size of this area as approximately $\$ 5$ ro per family. Since these advantages are enjoyed annually, the poor family should be willing to pay up to $\$ 5$, roo for the privilege of living in the high base suburb, where the sum $\$ 5,100$ is the present value of the future stream of advantages discounted at $10 \%$.

Will any single poor family voluntarily move into the rich suburb? The answer is no. Because the poor family's demand for the private, that is, nonfiscal advantages of the rich suburban location is so small (commuting is costly and their demand for open space is "weak"), the sum of the family's willingness to pay for the private and public advantages is still less than what the rich will pay for the same location. From our estimated land price gradient for $\$ 5,000$ families, see note 45 supra, we estimate that these families will pay at most $\$ 420$ per acre for the private advantage of land ten miles from the central city. Adding their maximum fiscal premium to the private value of an acre gives $\$ 5,520$ per acre as the maximum price any single poor family will pay to live in a rich suburb. Rich families, however, will pay at least $\$ 9,463$ per acre (the private value, when they cannot be sure that the rich suburb will house only other rich families), to as much as $\$ 2 \mathrm{I}, 945$ per acre (the joint private plus public fiscal value, when they can be sure of the rich suburb's income "purity," see note 45 supra).

But note that a coalition of four to five $\$ 5,000$ families can afford to buy an acre of land in the rich suburb. For example, a group of five will pay up to $\$ 25,920$ per acre $(=5 \times \$ 5,100+\$ 420)$, which will often be enough to buy land in a $\$ 25,000$ suburb, see note 45 supra. The acre can then be subdivided into four or five smaller plots. Of course the exact size of the poor family coalition depends on the price needed to buy the land. In general, however, it is clear that coalitions could buy into rich suburbs. 
growth control schemes and public referenda requirements have also become popular. ${ }^{51}$ To be sure, lower income families are still free to buy large houses which meet the zoning requirements. But this is a Pyrrhic victory; such houses are so expensive that any fiscal advantages accruing to the low income family from relocation will be outweighed by the increase in its housing costs.

For our typical metropolitan economy, we have calculated the zoning levels needed by each suburb in order to protect its tax base. The required zoning minimums were calculated by estimating the smallest coalition of lower income families which, when offering the highest price it is able to pay, can just buy an acre of suburban land for subdivision. If the rich suburb then zoned to require each acre to be purchased by fewer than the number of families in this "entry coalition," entry could be effectively denied. For the richest suburbs with families whose yearly incomes exceed $\$ 25,000$, we estimate that minimum lot sizes of 0.33 acres per plot will be sufficient to deter families whose incomes are $\$ 20,000$ or less. ${ }^{52}$ Using the same method of calculation, we estimate that to keep out all families whose incomes are below $\$ 15,000$ per year, the $\$ 20,000$ family income suburbs must set a minimum average zoning requirement of 0.30 acres per residential plot. To exclude the $\$$ ro,o0o or lower income families, the $\$$ I 5,000 income suburbs need minimum lot sizes of $0.5_{5}$ acres. Finally, the $\$$ Io,00o per year income suburbs need a minimum lot size of 0.10 acres to deter the very poor from relocating within their borders. ${ }^{53}$

${ }^{51}$ See, e.g., R. Babcock \& F. Bosselman, Exclusionary Zoning 3-22 (1973); B. Frieden, The Environmental Protection Hustre (1979); Developments, supra note 6 , at $1629-3$ I.

${ }^{52}$ For example, we have estimated, see note 50 supra, that one $\$ 5,000$ income family would pay up to $\$ 5,100$ for the fiscal advantages to be derived from living in a $\$ 25,000$ income suburb. Some unknown number $(X)$ of these families would pay an additional $\$ 420$ per acre for the private amenities of living in a $\$ 25,000$ suburb located ten miles from the central city, see note 5o silpra. Land currently sells in the richest suburb for $\$ 21,945$ per acre - the estimated price of land when $\$ 25,000$ suburbs contain only $\$ 25,000$ families, see note 45 supra. Since each family in the coalition will pay up to $\$ 5,100$ plus a share of the $\$ 420$ per acre, the minimum number of families required $(X)$ is determined by the relationship $\$ 5,100 X+\$ 420 /$ acre $=\$ 2 r_{2495 / a c r e}$. Solving for $X$, we compute the minimum number of $\$ 5,000$ families required to be roughly four. The rich suburb must therefore set the minimum land requirement per family at 0.33 acres or greater, so that only three poor families can live on an acre. For this privilege they will collectively pay only $(\$ 5,100)(3.0)+\$ 420 /$ acre $=\$ 15,720 /$ acre, which is less than the existing market price of $\$ 2 \mathrm{I}, 945$ per acre. Thus, the poor are excluded. By following the same procedure we find that the 0.33 acre requirement will also exclude $\$ 15,000$ and $\$ 10,000$ family coalitions seeking entry into the $\$ 25,000$ suburb.

${ }^{53}$ For a description of the calculation procedure, see note 52 supra. 
Do communities in fact zone to keep residential land densities above the level needed for full tax base protection and thus practice exclusionary zoning? Actual residential densities can be compared to the projected exclusionary zoning minimums for each jurisdiction in our typical metropolitan region. If actual densities exceed the estimated zoning minimums, then one can surmise that the zoning power is being used for exclusionary purposes. Our data for the typical metropolis show that $\$ 25,000$ communities in the suburban fringe have an actual residential density of 0.57 acres per family, ${ }^{54}$ which is larger than our estimate of the required zoning minimum of 0.33 acres per family; thus, it appears that those communities are engaging in exclusionary zoning. Actual land use levels observed in the $\$ 20,000$ per year, $\$ 15,000$ per year, and $\$ 10,000$ per year suburbs are $0.3 \mathrm{I}$ acres, o.I 7 acres, and o.II acres per family respectively, again indicating that whatever the intent, the zoning power does have an exclusionary effect. Exclusionary fiscal zoning is apparently a fact of life in our metropolitan economy. ${ }^{55}$

${ }^{54}$ The actual residential densities in each of the suburban communities are calculated in note 45 supra.

${ }^{55}$ Other evidence is consistent with this conclusion. See, e.g., Branfman, Cohen \& Trubek, Measuring the Invisible Wall: Land Use Controls and the Residential Patterns of the Poor, 82 YALE L.J. 483 (I973) (finding that regions with many independent zoning authorities show more clustering of families with like incomes than areas with fewer independent zoning authorities); Stull, Community Environment, Zoning, and the Market Value of Single-Family Homes, I8 J. LAw \& EcoN. 535 (1975) (finding that the value of land in richer suburbs declines as the percent of residential land zoned for multifamily dwelling rises). See generally Hamilton, Mills \& Puryear, The Tiebout Hypothesis and Residential Income Segregation, in Fiscai Zoning and Land Use Controls: The Economic Issues (E. Mills \& W. Oates eds. I975).

Also, our analysis of lower income families' willingness to pay to enter upper income suburbs suggests that a sizeable profit can be earned by the marginal rich resident who sells his property for subdivision. In the richest suburb where land initially sells for $\$ 2 \dot{r}, 945$ per acre, a single $\$ 5,000$ family would like to enter and purchase one-tenth of an acre plot (the family's demand for land at the $\$ 21,945$ per acre price) and capture the $\$ 5$, roo lifetime fiscal surplus, see note 50 supra. Ten $\$ 5,000$ income families could live on one acre. If each family contributes up to $\$ 5,100$ for the purchase of the acre a maximal total bid of $\$ 51,000$ could be offered by the group. If a rich town did in fact offer such an acre for sale (following a zoning amendment), the land would command a sizeable premium as several coalitions of poor families bid for the property. The likely selling price would be near $\$ 51,000$ per acre, a $\$ 30,000$ per acre premium over other residential land in the rich suburb. A recent empirical study, see Maser, Riker \& Rosett, The Effects of Zoning and Externalities on the Price of Land in Monroe County, New York (1974) (mimeo., University of Rochester), shows that premiums of exactly this magnitude $(\$ 30,000$ per acre) can accrue to multifamily zoned land in rich suburbs, see id. at II7 '(Table 33). 


\section{On Measuring Performance}

To many, the distributions of services and taxes represented in Tables I and II may seem unfair. Yet exactly what would constitute a more just allocation? Advocating increased local tax and service equity means little without a standard against which to measure gains. For the purposes of this Article, we shall measure local fiscal equity along two dimensions of performance: (I) the after-local-tax distribution of family incomes and (2) the distribution of local public service expenditures by income class. In offering our measures of equity performance, however, we must stress that no prior judgment as to "how much" equity is good or bad is necessarily implied.

I. Tax Equity. - With respect to tax equity, the key question is whether the structure of property taxation turns an unequal before-tax distribution of family incomes into a more equal aftertax distribution. One measure of the impact of a tax system on the distribution of income is the elasticity of after-tax income, denoted hereinafter by the symbol $\epsilon$. In accordance with standard usage, $\epsilon$ represents the percentage increase in after-tax income which occurs in response to a one-percent rise in before-tax income. $^{56}$ In this context, we are comparing the incomes of families as we move up the income distribution from poor to rich. For example, if a 1o\% rise in before-tax income (for example, from $\$ 10,000$ to $\$ I I, 000)$, results in a $10 \%$ increase in after-tax income (for example, from $\$ 8,000$ to $\$ 8,800$ ) then $\epsilon=\mathrm{I}$; the relationship between before-tax and after-tax income is a constant one. If a given percentage increase in before-tax income is more than matched by the percentage increase in after-tax income (for example, after-tax income rises from $\$ 8,000$ to $\$ 9,000$ ), then $\epsilon>$ I. If the percentage increase in after-tax income falls short of the percentage increase in before-tax income (for example, after-tax income rises from $\$ 8,000$ to $\$ 8,600$ ), then $\epsilon<\mathrm{x}$.

Computed values for $\epsilon$ allows us to measure the effects of local taxes on the distribution of income. When $\epsilon>I$ the tax structure is regressive (pro-rich) in that the tax system takes a larger share of income from the poor than from the rich - that is, tax rates fall as incomes rise. When $\epsilon=I$ there is a proportional relationship between before-tax and after-tax income; the tax system is drawing an equal percentage share of income from rich and poor alike. Finally, when $\epsilon<\mathrm{I}$, tax rates must be rising as incomes rise, and such a structure is thus progressive (pro-

${ }^{56}$ The measure $\epsilon$ was first suggested by Musgrave \& Thin, Income Tax Progression, 1929-48, $56 \mathrm{~J}$. PoL. ECON. 498 (1948), who referred to it as "residual income progression." 
poor). As $\epsilon$ approaches 0 , increases in before-tax income will result in virtually no gain in after-tax income; this situation is the extreme of tax equality as after-tax incomes are now equal for all families.

It is possible to determine values of $\epsilon$ for the typical tax distributions depicted in Tables I and II. While the dollar amount of property taxes paid by a family rises with before-tax income, the results show that they do not rise proportionally. Before adjustments for land premiums, $\epsilon$ is I.OI I for the central city, I.Ioo for the suburbs, and I.054 over the metropolitan region as a whole; the tax structure is regressive (see Table I). ${ }^{57}$ After adjustment for land premiums, the $\epsilon$ values for city, suburbs, and the region are I.0II, I.06, and $\mathrm{r.027}$, respectively (see Table II). Although slightly less regressive than the distribution of actual tax payments, net fiscal costs are also regressively distributed.

2. Expenditure Equity. - The elasticity concept is also useful in measuring the relationship between local service expenditures and before-tax income. The basic question is the same as before - but now, how does the dollar value of services received vary as income varies? The elasticity of local service expenditures, denoted by the symbol $a$, measures the percentage change in local expenditures associated with a given percentage increase in family income. The possible values for $a$ differ from those for $\epsilon$; $a$ may be positive, negative, or zero. If service outlays rise as family income increases, so that the distribution of service expenditures is pro-rich, $a$ is greater than zero. If all families receive the same level of local services regardless of income, a equals zero. When expenditure levels fall as income rises, reflecting the fact that the distribution of local public services is propoor, then $a$ is negative.

How does our hypothetical economy fare under the measure of expenditure equity? Earlier, we concluded that the distribution of service expenditures was regressive within the central city, among the suburbs, and over the metropolitan region as a whole. We also concluded that the suburban distribution was more prorich than that in the central city. Our estimates of $a$ illustrate these points. For the central city, $a$ equals 0.25 . For the suburbs, the value is 0.65 . Over the metropolitan economy as a whole, $a$ equals 0.35 (see Table I). ${ }^{58}$

${ }^{57}$ After-tax income elasticities were estimated as a simple regression of the logarithm of after-tax incomes ( $\log (Y)$ ) on the logarithm of before-tax incomes $(\log (I))$. This procedure is equivalent to approximating $\varepsilon$ in the relationship $Y=q I \epsilon$, where $\epsilon$ is the after-tax elasticity and $q$ is a simple constant. Observations for these calculations come from the results in Tables I and II for the five representative income classes.

${ }^{58}$ The elasticities of local service expenditures, $a$, were estimated as a simple 
3. Comparing Local Fiscal Equity. - While the values for $\epsilon$ and $a$ for the metropolitan economy are of interest in their own right, it is helpful to compare local governments' performance with that of state and federal governments. By estimating the equity performance of the state and federal sectors, we can better understand the potential and desirability of local fiscal reform. For comparison, we have estimated tax and spending equity at all levels of government. We will also consider what would happen if municipal services were provided by the private market.

A convenient basis for such comparisons is provided by Figure 2. Values of our measure of expenditure equity, $a$, are located along the horizontal axis; values of the tax equity parameter, $\epsilon$, are positioned along the vertical axis. Point $L(\epsilon=1.027$, $a=0.35$ ) in Figure 2 represents the overall equity performance of our typical metropolitan economy. Arrows pointing away from $L$ indicate the direction of increased equity. Equity gains can

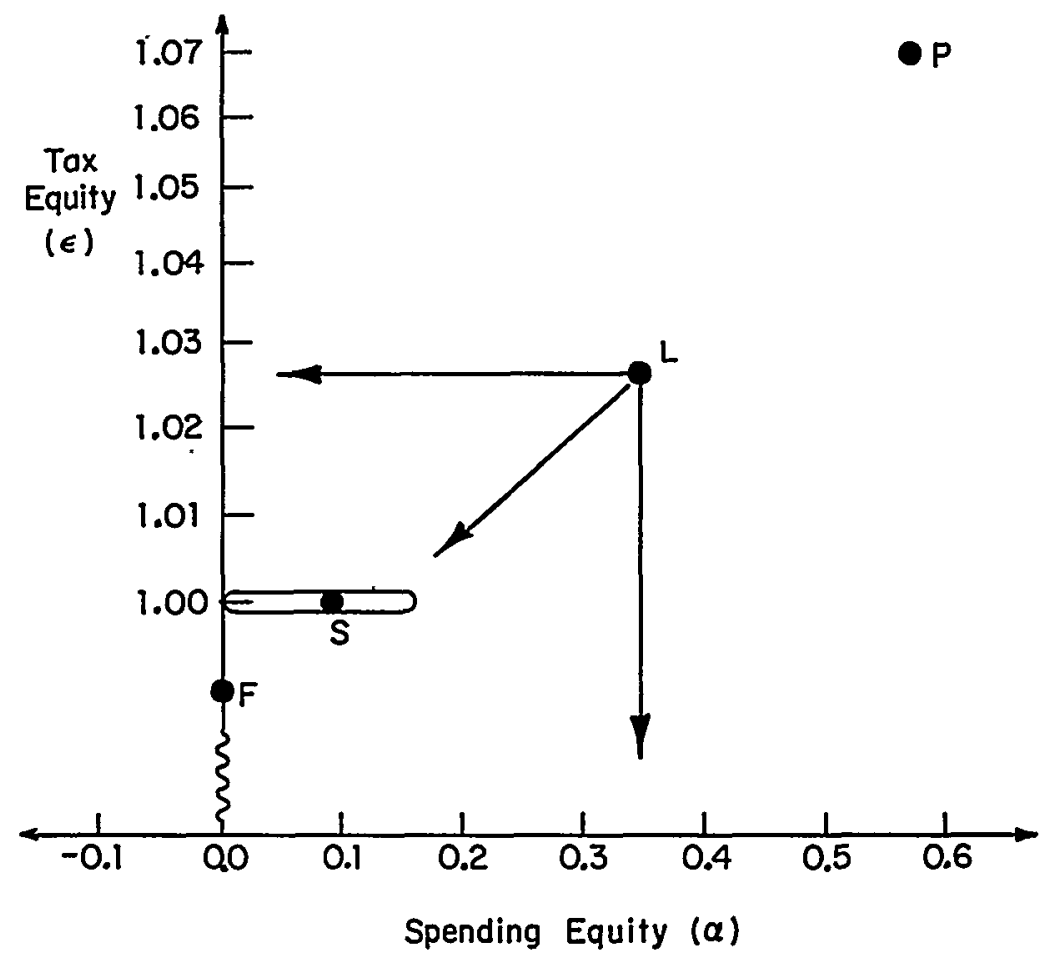

FIGURE 2

regression of the logarithm of expenditures ( $\log (G)$ ) on the logarithm of beforetax income $(\log (I))$. This procedure is equivalent to approximating $a$ in the relationship $G=v I a$, where $a$ is the elasticity of local service expenditures and $v$ is a simple constant. Observations for these calculations come from the results in Table I. 
occur by lowering $\epsilon$ while holding $a$ fixed (more progressive taxation, no expenditure changes), by lowering $a$ while holding $\epsilon$ constant (more progressive expenditures, no tax changes), or by reducing both $a$ and $\epsilon$ simultaneously. An expenditure or tax change which moves the economy away from $L$ represents a reduction in fiscal equity. ${ }^{59}$

Point $F$ in Figure 2 represents our best estimate of the federal budget's equity performance. The after-tax income elasticity $(\epsilon)$ of the federal personal and corporate income tax has been estimated to be between 0.93 and 0.96 , indicating a progressive distribution. ${ }^{00}$ The expenditure elasticity of federal outlays for education, health, parks, community improvements, environmental control, and physical safety - the services it provides which are similar to those provided by local governments - is more difficult to estimate, but on balance, federal expenditures seem to be fairly evenly distributed among the rich and poor ( $a$ is approximately zero). ${ }^{61}$ The federal government's equity performance is

${ }^{59}$ We shall emphasize throughout our analysis that no value judgments necessarily follow from any observed changes in $\epsilon$ and $\alpha$ as we move from one point in Figure 2 to another. Figure 2 is a descriptive, not a prescriptive, tool. Additional judgments are necessary before we can state one outcome in Figure 2 is to be preferred to any other. See, e.g., Atkinson, On the Measurement of Inequality, 2 J. Econ. TheoRY 244 (1970); Jakobsson, On the Measurement of the Degree of Progression, 5 J. PuB. Econ. I6I (1976). See also note 227 infra.

${ }^{60}$ Estimates of the after-tax income elasticity for the federal tax structure were calculated from data presented in J. PeCHMAN \& B. OKNER, WHo BEARS THE TAX BURDEN? 62 (I974). Depending on whether we use their "progressive" or "Iess progressive" assumptions, our estimate of a ranged from 0.93 to 0.96 .

1 The following five assumptions allowed us to allocate the distribution of the 1972 fiscal year federal budget:

(x) National defense expenditures were approximately $\$ \mathrm{I}, 503$ per family while federal expenditures on crime prevention averaged $\$ 24$ per family. Executtve Office of the Prestdent, Office of Management and Budget, The Budget of the United States Government, Fiscal Year 1974, H.R. Doc. No. 93- 5 , 93d Cong., Ist Sess. (1973) [hereinafter cited as THE BudGET, F.Y. 1974]. These expenditures are allocated equally across all income classes. (2) Environmental expenditures on pollution control, national parks, and forests averaged $\$ 32$ per family for fiscal year I972. THE BUDGET, F.X. I974The expenditures were allocated across income classes by assuming that families utilize these resources in proportion to their income.

(3) Health care expenditures include outlays for Medicaid (allocated only to families in the $\$ 5, \infty 00$ bracket), Medicare, and research. Medicare and research outlays were allocated as a fixed percentage of the private health care outlays by each income class. The percentage was set at 0.3 , which equals the ratio of total Medicare plus research expenditures to total private health care expenditures. The data are for 1972, and were obtained from BUREAU of the Census, U.S. Dep't of Commerce, Statistical Abstract of the UNITED STATES 70 (1975).

(4) Community development expenditures were allocated only to urban residents, but were assumed to be equally distributed within the urban area. 
significantly more progressive than that of the local public economy.

The narrow band around point $S$ represents a rough estimate of state government's equity performance. States draw their tax revenues predominantly from personal income taxes, sales taxes, and corporate income taxes. On balance, this tax structure is proportional; $\epsilon$ equals 1.00 in most states. $^{62}$ Estimating the distribution of expenditures, and hence $a$, is more problematic. The enclosed area surrounding point $S$ contains a band of possible equity performances. The implied overall state $a$ value is variable from state to state ranging from near 0.00 for those states with strong Medicaid programs to about 0.20 for states with low Medicaid support. ${ }^{63}$ In sum, the state governments'

Expenditures rise with income since more rich people live in urban than rural areas. Data were obtained from the following sources: THE BUdGet, F.Y. x974; Bureau of the Census, U.S. Dep't of Commerce, Statisticat Abstract of THE United States 385 (I974).

(5) Federal education expenditures were allocated as a fixed percentage of local education expenditures in order to reflect the fact that most federal outlays are "matching" funds. The average matching rate is approximately 0.05 . Data were obtained from THE BUDGET, F.Y. I974.

The resulting distribution of expenditures is presented in the following table:

Expenditures per Family on:

\begin{tabular}{|c|c|c|c|c|c|c|}
\hline Income & $\begin{array}{l}\text { Defense and } \\
\text { Crime }\end{array}$ & Environment & $\begin{array}{c}\text { Health } \\
\text { Care }\end{array}$ & $\begin{array}{l}\text { Community } \\
\text { Development }\end{array}$ & Education & Total \\
\hline 5,000 & $\mathrm{I}, 527$ & 8 & 425 & $\mathrm{I}_{4}$ & 26 & 1,990 \\
\hline $10, \infty \infty$ & $\mathbf{I}, 527$ & I6 & 237 & I5 & 25 & 1,820 \\
\hline I5,,$\infty 0$ & 1,527 & 24 & 300 & I7 & 32 & $x, 900$ \\
\hline 20,000 & $\mathrm{I}, 527$ & 32 & 323 & 18 & 38 & 1,938 \\
\hline 25,000 & 1,527 & 40 & 333 & 18 & 43 & $I, 961$ \\
\hline
\end{tabular}

These figures were used to compute the federal expenditure elasticity, $e$, as detailed in note 58 supra.

${ }^{62}$ States receive the bulk (approximately 60\%) of their tax revenues from general sales taxes with income taxes accounting for another $30 \%$. Property taxes, excise taxes, and licenses account for the remaining ro\%. J. PeCHMAN \& B. OKNER, supra note 60 , at 59 , provided the data needed to estimate $\epsilon$ for the general sales tax structure; we calculate $\epsilon$ to be approximately r.02. State income taxes are nominally proportional but per capita deductions make it slightly progressive. See U.S. Advisory Comarission on IntergovernMental Reiations, State-Local FINANCES AND SUGGeSted LeGisiation (1971) (Table 36). On balance, the weighted average value of $\epsilon$ for most states will fall at about r.oo.

${ }^{63}$ The distribution of state expenditures across income groups was determined using the same procedure employed for allocating federal outlays, see note $6 \mathrm{r}$ supra. We further assumed that state expenditures on education and safety are equally distributed and that environmental and health care expenditures matched their federal counterparts, so that expenditures on these services follow the federal pattern (though health care outlay varies), see note 62 supra.

The resulting distribution of expenditures is presented in the following table: 
performance is generally less equitable than that of the federal government, but more equitable than that of local governments.

Point $P$ in Figure 2 represents the predicted $a$ and $\epsilon$ values if local public services were no longer provided by the government sector but were allocated by the private market economy. Loosely speaking, the private economy raises its revenues for these expenditures through an "excise tax" — the market charges a uniform price per unit of services purchased. Since the price would be equal for both rich and poor, and since the poor spend a larger percentage of their income on these key services, the private market's implicit "tax" structure is regressive. We estimate that $\epsilon$ would equal $\mathrm{I} .08$ if the private market provided for local services. ${ }^{64}$ Assuming that, as family income rises, spending on services would rise, but at a slightly lower rate, and given the present distribution of private income, we estimate $a$ to have an average value of 0.50 to 0.60 for the private economy. ${ }^{65}$ Over-

Expenditures per Family on:

(\$)

\begin{tabular}{|c|c|c|c|c|c|}
\hline Income & Education & Environment & Health Care & Protection & Total \\
\hline 5,000 & 200 & 8 & $2 \mathrm{I} 2$ & 54 & 474 \\
\hline 10,000 & 200 & 16 & II 8 & 54 & 388 \\
\hline I5,000 & 200 & 24 & 150 & 54 & 428 \\
\hline 20,000 & 200 & 32 & I6I & 54 & 447 \\
\hline 25,000 & 200 & 40 & 167 & 54 & $46 I$ \\
\hline
\end{tabular}

These figures are used to compute our values for $a$ as in note 58 supra. In states with weak Medicaid programs, the strong pro-poor bias of health care outlays is lost and the estimated a value for state government reaches 0.2 .

${ }^{64}$ Here, $\epsilon$ is calculated as the percentage change in after-expenditure income caused by a given percentage change in before-expenditure income. On the basis of the data presented in note 65 infra, we estimate $\epsilon$ to be 1.08 when education is not privately purchased and I.10 when it is privately purchased.

${ }^{65}$ The elasticity, $a$, was computed on the basis of the numbers presented in the table below. These numbers are calculated using current consumption levels and the most recent empirical evidence on consumer behavior.

Family Expenditures on:

(\$)

Total

Expenditure

Health Environment

\begin{tabular}{|c|c|c|c|c|c|c|c|c|}
\hline $\begin{array}{l}\text { Income } \\
\text { (I) }\end{array}$ & $\begin{array}{c}\text { Care } \\
\text { (2) }\end{array}$ & $\begin{array}{c}(\operatorname{Land}) \\
(3)\end{array}$ & $\begin{array}{l}\text { Protection } \\
\text { (4) }\end{array}$ & $\begin{array}{c}\text { Education } \\
\text { (5) }\end{array}$ & & $\begin{array}{l}\text { ation) } \\
6 \text { ) }\end{array}$ & & $\begin{array}{l}\text { ation) } \\
\text { (7) }\end{array}$ \\
\hline 5,000 & 672 & 374 & 33 & 504 & $I, 583$ & & 0.32 & \\
\hline 10,000 & 790 & 440 & 66 & 720 & 2,016 & & 0.20 & \\
\hline I 5,000 & 900 & 500 & 100 & $I, \infty 00$ & 2,500 & $(\mathrm{I}$, & 0.17 & \\
\hline 20,000 & 980 & 540 & & 200 & 2,852 & & .14 & \\
\hline 25,000 & 054 & 580 & 165 & 1,380 & 3,179 & $(1,799)$ & 0.13 & \\
\hline
\end{tabular}

Mean family income in the U.S. is about $\$ 15,000$ per family with average yearly expenditures in the private market on health care of $\$ 900$ per family, $\$ 500$ per 
all, a private market would be even more regressive than the current metropolitan public economy (compare Point $P$ with Point $L$ ).

Our comparison of local, state, and federal government equity performance dramatizes the regressivity of local taxation and spending. Given the values for $a$ and $\epsilon$ cited above, it is not surprising that local governments have come under attack from those who advocate increased taxation and spending equity. In an effort to improve the equity performance of the local public sector, the reformers have turned not only to political action an approach of limited utility since politics are partly responsible for the present inequalities - but also to the courts.

\section{Judicial Reform of Local Public Finance}

A number of recent federal and state court cases have evidenced a desire on the part of the judiciary to improve local government's fiscal performance. The development has been far from uniform; some jurisdictions have made extensive efforts to increase local fiscal equity, while others have rejected the overtures for reform or have failed to institute meaningful remedial measures. Four particular subjects have received considerable judicial attention: (I) whether municipal services must be equally allocated among a community's residents; (2) whether tax assessments for residential property must be uniform within a locality; (3) whether services such as education may be financed through purely local taxes even when such funding results in an unequal spending distribution among communities; and (4) whether exclusionary local zoning and land use controls are acceptable. In this Part, we will describe the judicial response to

family for land (approximately ro\% to $20 \%$ of annual housing costs), $\$ 100$ per family for safety and protection, and $\$ 1,000$ per family for education (public or private). Estimates of expenditures for families with $\$ 10,000$ and $\$ 20,000$ incomes are calculated from statistically estimated demand relationships, which imply the average income elasticity of demand for health care is 0.3 , see Feldstein, Econometric Studies of Health Economics, in Frontiers of QUANTITative EcoNomrcs (M. Intriligator \& D. Kendrick eds. 1974), for family ownership of land, 0.3 , see M. Straszheim, An Econometric Analysis of Urban Housing Markets '(1975), for fire and police protection, x.o, see Bergstrom \& Goodman, Private Demand for Public Goods, 63 AM. Econ. REv. 280 (1973), and for clementary and secondary education, 0.6 to 0.7 , see Inman, supra note 29.

The statistics in column 6 are the total expenditures if education were provided by the private market. The numbers in parentheses represent the total expenditures when education is provided publicly and therefore excluded from the private market bundle. Column 7 specifies the percentage of before-expenditure (beforetax) income spent on health care, environment, protection, and education. The percentage falls as private income rises. 
each of these issues by indicating the jurisdictions involved, the legal doctrines utilized, and the remedial measures employed. So that we can test the potential of judicial reform, taken to its limits, the broad principles or "strategies for change" underlying the various opinions will be identified.

\section{A. Intrajurisdictional Service Equity}

Tax base disparities and expenditure differences among political jurisdictions are not the only sources of fiscal inequality in the urban economy. Within a single jurisdiction, the allocation of services among residents may be unequal. The existence of expenditure differentials within communities has inspired a number of lawsuits. 60

The paradigm case was presented in Hawkins v. Town of Shaw, ${ }^{67}$ where the Fifth Circuit found that Black residents received unequal treatment from the town in the provision of lighting, sewers, and street services. The severity of the service differential was held sufficient to justify a finding of liability under the equal protection clause. The case has been hailed by several commentators, who have explored both its theoretical underpinnings and its legal potential. ${ }^{68}$

The basis of liability in Hawkins was uncertain; the principal opinion seemed to use both an intent standard and an effect standard, ${ }^{69}$ while Judge Wisdom, concurring in the judgment, relied solely on the discriminatory effect of the service differentials. ${ }^{70}$ In light of recent Supreme Court determinations, it is now apparent that intent to discriminate must be proven before liability can be assessed. ${ }^{71}$ The extreme situation presented in Hawkins may provide sufficient circumstantial evidence from which to infer intent, ${ }^{72}$ but the intent requirement calls the precedential value of another service equalization case, Hobson $v$.

${ }^{8 B}$ See generally Lineberry, Mandating Urban Equality: The Distribution of Municipal Public Services, 53 Tex. L. Rev. 26 (r974); Fessler \& Haar, Beyond the Wrong Side of the Tracks: Municipal Services in the Interstices of Procedure, 6 Harv. C.R.-C.L. L. Rev. 44I (I97I).

${ }^{67} 437$ F.2d I286 (5th Cir. I97I), aff'd on rehearing, $46 \mathrm{x}$ F.2d Ix7I (5th Cir. 1972) (en banc).

${ }^{68}$ See, e.g., Lineberry, supra note 66; Note, Hawkins v. Town of ShawEqual Protection and Municipal Services: A Small Leap for Minorities but a Great Leap for the Commentators, I97 I UTAH L. REV. 397 .

${ }^{60} 46 \mathrm{x}$ F.2d at $\mathrm{xI72-73.}$

${ }^{70} \mathrm{Id}$. at II74.

${ }^{71}$ See, e.g., Village of Arlington Heights v. Metropolitan Hous. Dev. Corp., 429 U.S. 252 (I977); Washington v. Davis, 426 U.S. 229 (1976).

${ }^{72}$ See generally McGee, Illusion and Contradiction in the Quest for a Desegregated Metropolis, x976 U. Ir工. L.F. 948, 964-82. 
Hansen, ${ }^{73}$ into question. In that case, plaintiffs challenged the pattern of expenditures in the Washington, D.C., school system. Specifically, the plaintiffs alleged that the classifications used to allocate resources among schools were in violation of the equal protection clause, citing the fact that student-teacher ratios were smaller and average teachers' salaries were higher in White schools than in Black schools. ${ }^{74}$ The district court held that all schools within a single school system must be run on an equal basis, at least with respect to the "objectively measurable aspects" of their operation. ${ }^{75}$ It is questionable whether the resource differentials established in Hobson were so dramatic as to justify imposing liability under an intent standard. ${ }^{76}$

The precedential value of Hobson is also called into question because it seems to have relied not only on the presence of racial discrimination, but also on the presence of discrimination against the poor. ${ }^{77}$ The question of whether wealth classifications should receive heightened judicial scrutiny has been much debated. ${ }^{78}$ In San Antonio School District v. Rodriguez, ${ }^{70}$ however, the Supreme Court mooted the issue by holding that, in general, wealth is not a suspect class.

Read broadly, Hawkins seems to require the equitable allocation of service expenditures within communities. The adage that equality "[o]nce loosed, . . . is not easily cabined," ${ }^{80}$ has not proved.accurate in this case, however. The range of applications of Harekins is clearly limited by the establishment of an intent requirement, and by the Supreme Court's refusal to hold

${ }^{73}{ }_{269}$ F. Supp. 401 (D.D.C. Ig67), aff'd sub nom. Smuck v. Hobson, 408 F.2d I75 (D.C. Cir. I969) (en banc).

${ }^{74} 269$ F. Supp. at $436-38$.

${ }^{75} I d$. at 496 .

${ }^{76}$ Without other evidence of intent, discriminatory effect demonstrates the existence of illicit purpose only in extreme cases. See Village of Arlington Heights v. Metropolitan Hous. Dev. Corp., 429 U.S. 252, 266 (I977). See also Castaneda v. Partida, 430 U.S. 482 (I977).

${ }^{77} 269$ F. Supp. at $496-97,507-08$.

${ }^{78}$ See, e.g., Michelman, The Supreme Court, I968 Term-Foreword: On Protecting the Poor Through the Fourteenth Amendment, 83 HARv. L. REv. 7 ( 1969$)$.

${ }^{79}$ III U.S. I (1973). The Court did suggest that in certain circumstances, classifications based on wealth would be subject to strict scrutiny. See id. at 25 n.6o. See also p. I700 infra. Also, if wealth classifications impair established fundamental interests then the classification will fall. See, e.g., Shapiro v. Thompson, 394 U.S. 6I8 (I969) (right to travel); Edwards v. California, 314 U.S. $\times 60$ (I94I) (same); Griffin v. Illinois, 35I U.S. I2 (r956) (access to courts). In general, however, as most recent decisions confirm, wealth is not a suspect class. See, e.g., Maher v. Roe, 432 U.S. 464, 470-7I \& n.6 (I977).

${ }^{80} \mathrm{Cox}$, The Supreme Court, 1965 Term-Foreword: Constitutional Adjudication and the Promotion of Human Rights, 80 HARv. L. REv. 9I, 9I (Ig66). 
that wealth is a suspect class. A further limitation is implicit in the judiciary's refusal to attack schemes in which municipal services are financed through special assessments or user charges. The courts have held that a local government does not discriminate against neighborhoods when it uses special assessments, since it provides the additional services to any and all groups who are willing to pay. ${ }^{81}$ But if a particular group or neighborhood is unable to organize or to bear the cost of the service, it will be deprived of the advantages accruing to more affluent groups or neighborhoods. ${ }^{82}$ Thus, if extended to include most municipal services, special assessment financing could lead to substantial service inequalities.

If the federal courts were willing to hold that certain services are fundamental, an approach suggested by several commentators, ${ }^{83}$ then the locality might be required to finance those services through general revenues disbursed in an equitable fashion. The judiciary has uniformly rejected such a doctrine, however. ${ }^{84}$ The same sort of limitation could be achieved if the courts accepted dicta contained in Rodriguez that suggests that special user charges would be suspect under the equal protection clause. In

${ }^{81}$ See, e.g., Hadnott v. City of Prattville, 309 F. Supp. 967, 970 (M.D. Ala. r970) (differences due to the "willingness [of homeowners] to pay for the property improvements" do not violate the equal protection clause). See also Fire v. City of Winner, 352 F. Supp. 925 (D.S.D. I972) (provision of street paving, sidewalks, and sewage facilities is responsibility of property owner and thus should be paid for through special assessments). This principle is consistent with the courts' application of the one-man-one-vote doctrine to local governments. They have allowed departures from the doctrine where an election involves local units established for a "special limited purpose" which have a "disproportionate effect" on particular groups, such as landowners, see, e.g., Salyer Land Co. v. Tulare Lake Basin Water Storage Dist., 410 U.S. 719, 728 (1973), but have required strict adherence in elections of more general impact, see, e.g., Kramer v. Union Free School Dist. No. 15, 395 U.S. 250 (1969) (school board elections).

${ }^{82} \mathrm{Cf}$. Citizens for Underground Equality v. City of Seattle, 6 Wash. App. 338, 492 P.2d 107I (1972) (rejecting claim that statute allowing neighborhoods to form local improvement districts discriminated against communities unable to take advantage of the provision). See generally Fessler \& May, The Municipal Service Equalization Suits: A Case of Action in Quest for a Forum, in Public Needs and Private Bemavior in Metropolitan Areas i70-7I (J. Jackson ed. $x 976)$.

${ }^{83}$ See, e.g., Michelman, States' Rights and States' Roles: Permutations of "Sovereignty" in National League of Cities v. Usery, 86 YALE L.J. II65, II8I-9I (I977); Tribe, Unraveling National League of Cities: The New Federalism and Afirmative Rights to Essential Government Services, 90 HARv. L. REv. ro65 (I977).

${ }_{84}$ See, e.g., San Antonio Indep. School Dist. v. Rodriguez, 4II U.S. I (1973) (education); Goldstein v. City of Chicago, 504 F.2d 989 (7th Cir. 1974) (garbage collection); Jackson v. New York City Health and Hosp. Corp., 4I9 F. Supp. 809 (S.D.N.Y. 1976) (medical facilities); Towns v. Beame, 386 F. Supp. 470 (S.D.N.Y. I974) (fire protection). 
that case, the Supreme Court stated that "[i]f elementary and secondary education are made available by the state only to those able to pay a tuition assessed against each pupil, there would be a clearly defined class of 'poor' people - definable in terms of their inability to pay the prescribed sum - who would be absolutely precluded from receiving an education." ${ }^{85}$ Thus, such deprivations would result in a higher level of judicial scrutiny. ${ }^{80}$ If this concept of absolute deprivation were expanded to cover important services other than education, then the use of special assessment financing could be constrained.

Even in situations where the courts are willing to employ a Hawkins approach and require a more equitable distribution of service expenditures, two additional problems arise. First, it is extremely difficult to determine whether service inequalities exist. The degree of inequality present can be measured either in terms of input (expenditures) or in terms of output (quality of service). Although most courts have focused on the former, ${ }^{87}$ expenditures are frequently an inaccurate and unfair ${ }^{88}$ measure of service equality. On the other hand, determining the quality of service provided is extremely complex. But in the absence of a clear finding of service differentials, the federal courts will not impose liability. ${ }^{89}$

Second, the federal courts may be unwilling to provide an ef-

${ }^{85} 4$ Ir U.S. at 25 n.6o.

${ }^{80} \mathrm{Id}$.

${ }^{87}$ See, e.g., Beal v. Lindsay, 468 F.2d 287, 290-9I \& n.4 (2d Cir. I972); Hobson v. Hansen, 327 F. Supp. 844 (D.D.C. r97I).

${ }^{88} \mathrm{If}$, for example, a neighborhood contains an old school structure for which maintenance costs are high, a simple equality of expenditures might suggest that the distribution of services among neighborhoods is equitable, when in fact it is not.

${ }^{89}$ See, e.g., McInnis v. Shapiro, 293 F. Supp. 327, 335-36 (N.D. Ill. I968), $a f f^{\prime} d$ sub nom. McInnis v. Ogilvie, 394 U.S. 322 (I969) (determining whether inequality exists in school expenditure case too difficult); Jackson v. New York City Health \& Hosp. Corp., 4I9 F. Supp. 809, 8I2 (S.D.N.Y. 1976) (closing certain health facilities found legal since scrutinizing local discretion would raise intractable economic, social, and even philosophical problems); Burner v. Washington, 399 F. Supp. 44 (D.D.C. I975) (evidence of input disparities in provision of police, recreation, fire, and refuse collection services found inconclusive). Sec also Towns v. Beame, 386 F. Supp. 470 (S.D.N.Y. 1974) (local decision to close certain fire stations was justified, given budget restrictions and neutral basis for choosing which stations to close). In cases where the inequities are clear, however, courts will still employ a Hawkins-type approach. See Green v. City of Memphis, 535 F.2d 976 (6th Cir. r976) (closing of streets in White community to create privacy may violate equal protection clause if Black communities are not treated in the same way); Johnson v. City of Arcadia, 450 F. Supp. 1363 (M.D. Fla. r978) (small community's spending favors Whites over Blacks); Selmont Improvement Ass'n v. Dallas County Comm'n, 339 F. Supp. 477 (S.D. Ala. 1972) (failure to pave roads in Black communities violated Hawkins doctrine). 
fective remedy. In some cases, the courts have been extremely flexible in granting relief. In a subsequent ruling in Hobson, the school system was ordered to reallocate expenditures so that the per pupil expenditures in the poor, minority schools would be within five percent of the systemwide average. ${ }^{90}$ Other decrees have been even more specific. For example, courts have ordered localities to pave specified roads. ${ }^{91}$ In general, however, two factors serve to limit the traditional presumption of flexibility accorded to federal courts in designing effective remedies. ${ }^{92}$ First, the judiciary is reluctant to order local governments to spend funds otherwise subject to the discretionary control of local officials. ${ }^{93}$ Second, recent Supreme Court opinions have evidenced a general unwillingness to interfere with local control and initiative. ${ }^{9 *}$ This concern for federalism will tend to make the courts even less receptive to Hawkins-type actions.

In summary, the federal law currently provides some protection against the distribution of services among neighborhoods within a community only where it is the result of intentional racial discrimination. The difficulty of determining whether a service inequality exists, and the courts' reluctance to grant truly effective relief, further limit the reach of Hawkins..$^{95}$ Nonetheless, in order to test the implications of the Hawkins approach, taken to its limits, we will examine the economic effects of requiring that intrajurisdiction expenditures must be equal across all income groups.

\section{B. Intrajurisdictional Taxpayer Equity}

In order to achieve intrajurisdictional taxpayer equity, variations in property valuation practices within communities must be

${ }^{80}$ Hobson v. Hansen, 327 F. Supp. 844, 863-64 (D.D.C. I97I).

${ }^{01}$ See, e.g., Johnson v. City of Arcadia, 450 F. Supp. I362 (M.D. Fla. I978) (enjoining further service improvements until locality makes court-ordered improvements in specific roads and recreational facilities); Selmont Improvement Ass'n v. Dallas County Comm'n, 339 F. Supp. 477, 48I-84 (S.D. Ala. I972) (paving of particular roads ordered).

${ }^{02}$ See, e.g., Swann v. Charlotte-Mecklenburg Bd. of Educ., 402 U.S. I, 15 (I97I) (equitable remedies characterized by "breadth and flexibility").

${ }^{23}$ See generally Frug, The Judicial Power of the Purse, I26 U. PA. L. REv. 715, 7I6-I7 (I978).

${ }^{84}$ See, e.g., Rizzo v. Goode, 423 U.S. $362,375-80$ (1976); Milliken v. Bradley, 418 U.S. 7I7 (r974). See generally Developments in the Law-Section I983 and Federalism, 90 Harv. L. Rev. II33, I240-50 (1977).

${ }^{85}$ Given the limited reach of federal law, it is not surprising that the state courts have been called on to provide relief. See, e.g., Fessler \& May, supra note 82 , at 187 . State courts have not been receptive to such challenges. See, e.g., Sattler v. Askew, 259 So. $2 \mathrm{~d} 289$ (Fla. I974) (dismissing complaint alleging improper allocation of road paving funds). 
eliminated. ${ }^{96}$ Ordinarily, an individual's local taxes are a function of the assessed value of his property. Small differences in that assessed value can result in substantial tax differences for homeowners, and to the extent that property taxes are passed on in higher rents, for renters as well. In addition, assessment differentials may affect the market or sale price of properties as purchasers react to either the favorable or unfavorable assessments. Thus, systematic variations in assessment practices within a community may have the effect of penalizing or rewarding specific individuals, or even entire neighborhoods. ${ }^{.7}$ Especially if related to the racial composition of particular communities, these variations present striking examples of fiscal inequity. As a result of chronic overassessment, minority neighborhoods may well be paying more in taxes expressed as a percentage of total actual value than the citywide average, even though they are receiving equal or fewer public services.

Despite the need for reform, the federal courts have played virtually no part in correcting assessment inequalities. ${ }^{08}$ While the equal protection clause ostensibly requires that all property within a given class be taxed similarly, ${ }^{00}$ Supreme Court opinions have made it clear that local taxing practices will be subject to the minimal level of judicial scrutiny. ${ }^{100}$ In addition, federal intervention is limited by the Tax Injunction Act. ${ }^{101}$ The act, which proscribes federal court review of local taxing decisions so long as the state law provides a "plain, speedy, and efficient remedy," ${ }^{102}$ has been interpreted to require only an "adequate state remedy." 103

${ }^{96}$ See, e.g., Hellerstein, Iudicial Review of Property Tax Assessments, 14 TEX. L. Rev. 327 (I959); Luce, Assessment of Real Property for Taxation, 35 MICH. L. REv. I2I7 (1937); Note, Inequality in Property Tax Assessments: New Cures for an Old Ill, 75 HARv. L. Rev. 1374 (1962).

${ }^{97}$ See notes $4 \mathrm{I}, 42$ supra.

${ }^{98}$ See generally Clement, Discrimination in Real Property Tax Assessment: A Litigation Strategy for Pennsylvania, 36 U. PIrr. L. REv. 285 (1974); Note, supra note 96 , at $1375-76$.

${ }^{99}$ See, e.g., Township of Hillsborough v. Cromwell, 326 U.S. 620, 623 (1946); Sioux City Bridge Co. v. Dakota County, 260 U.S. 44r (rg23).

${ }^{100}$ See, e.g., Sunday Lake Iron Co. v. Township of Wakefield, 247 U.S. 350, 353 (rgI8) (requiring violation "which in effect amounts to an intentional violation of the essential principle of practical uniformity"); Lehnhausen v. Lake Shore Auto Parts Co., 4to U.S. 356 (I973); Charleston Fed. Sav. \& Loan Ass'n v. Alderson, 324 U.S. I82, I90-9I (1945); Nashville C. \& St. L. Ry. v. Browning, 3 10 U.S. 362 (1940); New York Rapid Transit Co. v. City of New York, 303 U.S. 573 (1938). See generally Clement, supra note 98, at 3r4-17; Comment, The Road to Uniformity in Real Estate Taxation: Valuation and Appeal, 124 U. PA. L. REv. I4I8, I420-2I (I976).

10128 U.S.C. $\S$ I 34 I ( 9976$)$.

102 Id.

${ }^{103}$ See, e.g., Kistner v. Milliken, 432 F. Supp. 100r, 1005 (E.D. Mich. 1977). HeinOnline -- 92 Harv. L. Rev. 1702 1978-1979 
The barriers to federal court action are not absolute, however, and in Garrett v. Bamford, ${ }^{104}$ the Third Circuit rejected the defendant's argument that the Tax Injunction Act required dismissal of a suit in which plaintiffs alleged a racially discriminatory pattern of local assessment. The court stressed that although state procedure provided ample opportunity for individuals to challenge a particular assessment decision, it did not allow review of community-reide variations in assessment practices. ${ }^{105}$ This result seems reasonable, ${ }^{106}$ and is consistent with Hawkins, which also required careful scrutiny of racially motivated local financing decisions. ${ }^{107}$

State law has been much more responsive to intrajurisdictional tax inequities than its federal counterpart. ${ }^{108}$ Most state constitutions require "uniformity" 109 or its equivalent in the treatment of all property within a given class. ${ }^{110}$ Moreover, many states specify by statute the percentage of true value at which property must be assessed. ${ }^{111}$ Despite the constitutional and statutory framework of equality, however, few states have voluntarily complied with these requirements. ${ }^{112}$

A recent series of state law decisions, however, has begun to enforce the constitutional and statutory requirements of equal

These holdings are based not only on construction of the act itself, but also on Supreme Court cases decided before the act, see, e.g., Matthews v. Rodgers, 284 U.S. 521 (1932), which were deferential to local governments.

${ }^{104} 538$ F.2d 63 (3d Cir.), cert. denied, 429 U.S. 977 (I976).

${ }^{105} 538 \mathrm{~F} .2 \mathrm{~d}$ at $70-7 \mathrm{r}$. Particularly relevant was the state system's failure to provide for joinder or class actions, thus forcing a single individual to bear the expense of presenting evidence on community-wide practices. $I d$.

${ }^{100}$ See Case Comment, Racial Discrimination and the Tax Injunction Act: Garrett v. Bamford, go HaRv. L. Rev. 6I6 (I977).

${ }^{107}$ As was the case with Hawkins, the scope of Garrett is uncertain. Most important, it is not clear whether Garrett permits taxpayer challenges to assessment practices as discriminatory on the basis of some factors other than race. This raises the question of the extent to which federal constitutional law protects against wealth classifications. See p. 1698 supra.

${ }^{108}$ See generally Comment, supra note 100 , at $I_{42} \mathrm{I}-28$.

${ }^{100}$ See, e.g., Idaho Const. art. VII, § 5; PA. Const. art. 8, § r.

${ }^{110}$ See generally U.S. AdVISORY COMM'N ON IntergovernMantal ReLAtrons, The Property Tax in a Changing Environment (I974).

${ }^{111} I d$. at 7-8. The most common requirement is that property be assessed at full value. $I d$. Of course, full value is itself an ambiguous concept, and numerous methods of valuation exist. See, e.g., Comment, supra note I00, at 1430-40; Note, Tax Assessments of Real Property: A Proposal for Legislative Reform, 68 YadE L.J. 335, 344-59 (1958).

${ }^{112}$ See, e.g., Note, supra note 96 , at $1376-80$. Underassessment may occur because localities are trying to receive state aid or are attempting to avoid the payment of county or state taxes, both of which are based on property assessments. Underassessments may also be the result of administrative inefficiency or incompetence. Id.' See generally Engle, De Facto Discrimination in Residential Assessments, 28 NAT'L TAX J. 445 (I975). 
treatment. In the seminal case of Switz v. Township of Middletoren, ${ }^{113}$ the New Jersey Supreme Court upheld a lower court decision directing local tax officials to comply with a state law which required all property in the township to be valued at full and fair value. In Bettigole v. Assessors of Springfield, ${ }^{114}$ the Massachusetts Supreme Judicial Court enjoined local authorities from classifying property and then assessing property within separate classes at different percentages of full market value. It went even further in Sudbury v. Commission of Corporations and Taxation, ${ }^{115}$ when it ordered the Commissioner of Corporations and Taxation to direct local assessors to take action to produce assessment uniformity throughout the state. ${ }^{116}$

Often, the failure to apply state law requiring uniform or full value assessments is justified on the ground that other statutes approve nonuniform or less than full value assessments. In $\mathrm{Hel}$ lerstein v. Assessor of the Town of Islip, ${ }^{117}$ however, the New York Court of Appeals rejected the argument that other statutory provisions overrode the clear meaning of the assessment provisions. ${ }^{118}$ Moreover, the court refused to give any weight to the contention that because the practice of valuing below the statutory norm was longstanding, it was immune from attack. ${ }^{110}$

There has been some resistance to judicial enforcement of intrajurisdictional tax base equity. In Massachusetts, for example, the electorate recently adopted a constitutional amendment which permits classification of property and the assessment of property at less than full value. ${ }^{120}$ So long as classification does not differentiate among various types of residential property, however, the focus of our concern - residential taxpayer equity - is unaf-

${ }^{113} 23$ N.J: 580, 130 A.2d I5 (1957).

114343 Mass. 223, I78 N.E.2d Io (x96r).

${ }_{115} 366$ Mass. 558, 32I N.E.2d 64x (1974).

${ }^{116}$ For empirical evidence relevant to Sudbury, see Rubinfeld, The Determination of Equalized Valuation: A Massachusetts Case Study, 3 Pub. Finance Q. 153 (1975).

${ }_{117} 37$ N.Y.2d $x, 332$ N.E.2d $279,37 x$ N.Y.S.2d 388 (1975), modified mem., 39 N.Y.2d 920, 352 N.E.2d 593, 386 N.Y.S.2d 406 (x976).

${ }^{118} 37$ N.Y.2d at 9,332 N.E.2d at 284,37 N N.Y.S.2d at 395.

${ }^{119}$ Id. at 13,332 N.E.2d at 286,37 I N.Y.S.2d at 398 (underassessment has "time on its side and nothing else"). Legislative complacency in the face of longstanding noncompliance bas led one court to tolerate departures from the statutory ideal. See Deitch Co. v. Board of Property Assessment, 417 Pa. 213, 2I7-I8, 209 A.2d 397, 400-0I (I965).

For other decisions requiring greater intrajurisdictional tax equality, see $\mathrm{McNayr}$ v. Dupont Plaza Center, Inc., I66 So. 2d I42 (Fla. I96r); Idaho Tel. Co. v. Baird, 9I Idaho 425, 423 P.2d 337 (I967); Park Inv. Co. v. Board of Tax Appeals, I75 Ohio St. 410, 195 N.E.2d 908, cert. denied, 379 U.S. 818 (I964).

${ }^{120}$ In Massachusetts, the electorate recently enacted a constitutional amendment dictating variable assessment rates. See Mass. Const., pt. 2, ch. I, art. IV. 
fected. ${ }^{121}$ Thus, in accordance with our desire to test judicial reform at its outer limits, we will assume that cases such as Hellerstein successfully mandate intrajurisdictional taxpayer equity in the form of uniform assessments.

\section{Interjurisdictional Tax Base Equity}

Equal spending and uniform property assessment requirements may set new standards for the financing and distribution of services within a local jurisdiction. Recently, state supreme courts have also begun to move towards mandating fiscal equity among jurisdictions. ${ }^{122}$ Substantial differences in community spending levels may result if local public services are funded primarily by taxing local rather than regional or state resources. In particular, where local property taxes are the primary source of revenues for public services, and there are major differences in the value of taxable property among localities, equal tax rates will support very different levels of public services. For example, a $2 \%$ tax on property in a community with a fiscal base of $\$ 30,000$ per family will support $\$ 600$ per family of public spending, while the same tax rate in a community with a $\$ 60,000$ per family fiscal base will support $\$ \mathrm{r}, 200$ per family in local spending. It is not surprising, therefore, to find that disparities in local tax bases are associated with a wide distribution of local services. ${ }^{123}$

At least in the field of education, state courts have endeavored to eliminate differences in spending resulting from tax base inequalites. In Serrano v. Priest ${ }^{124}$ and Horton v. Meskill ${ }^{125}$ the

${ }^{121}$ We do not examine the economic consequences of assessment equity for commercial and industrial properties in detail in this Article, but there is good reason to suspect that equalizing assessments within the commercial property class may, paradoxically, have adverse longrun consequences for achieving equality within the residential property class. See note 176 infra.

122 The problem of ensuring interdistrict fiscal equity was relegated to state courts following the Supreme Court's opinion in San Antonio Indep. School Dist. v. Rodriguez, 4II U.S. I (I973). In Rodriguez, the Court found that inequalities in school financing created by reliance upon local property taxes did not violate the equal protection clause of the Constitution, both because education is not a fundamental interest, $i d$. at 35 , and because classification by district is not suspect even though districts vary in wealth, id. at 28 . See also p. 1698 supra. Of course, federal courts may still scrutinize interdistrict tax rates in cases involving constitutional arguments other than those rejected in Rodriguez. See, e.g., Evans v. Buchanan, 447 F. Supp. 982, 1020-35 (D. Del. I978), aff'd, 582 F.2d 750 (3d Cir. 1978) (en banc) (court sets tax rate for II consolidated districts in context of school desegregation litigation).

${ }^{123}$ See pp. $1667-96$ supra.

${ }^{124}$ The Serrano $v$. Priest litigation actually resulted in two decisions by the California court. In Serrano v. Priest (Serrano I), 5 Cal. 3d 584, 487 P.2d I24I, 96 Cal. Rptr. 60I ( $997 \mathrm{I}$ ), the court reversed a lower court ruling dismissing a complaint challenging the school financing system. The court held that if the plaintiff could prove that variations in revenue-raising abilities resulted in dif- 
California and Connecticut Supreme Courts invalidated, on state constitutional grounds, state systems of public education financing which were based upon local property taxes. ${ }^{120}$ The two cases shared a similar approach. ${ }^{127}$ The financing schemes were found unconstitutional precisely because differences in the value of property present within each district led to wide variations in the ability of school districts to raise funds for education. ${ }^{28}$ Both courts emphasized that the existence of tax base inequalities meant that a fiscally poor community would have less revenues available for educational spending, even if its tax rate was equal to the rate in fiscally rich districts; thus, children in poorer communities were discrmiinated against in the provision of educational services. ${ }^{120}$ The relief provided in Serrano and Horton was

ferences in educational opportunity, then violations of both the state and federal constitutions would be found. Id. at 589, 596 n.Ir, 487 P.2d at 1244,1249 n.xr, 96 Cal. Rptr. at 604, 609 n.Ir. Serrano v. Priest (Serrano II), I8 Cal. 3d 728, 557 P.2d 929, I35 Cal. Rptr. 345 (1976), was an appeal from the decision on the merits. The California Supreme Court affirmed the lower court's finding of unconstitutionality despite recent legislative alterations in the California school finance system, and despite the United States Supreme Court's intervening decision in San Antonio Indep. School Dist. v. Rodriguez, 4II U.S. I '(1973). Since Rodriguez precluded the Serrano $I$ interpretation of the federal constitution, Serrano II places the decision squarely within the ambit of the state constitution. I8 Cal. 3d at 760-68, 557 P.2d at 947-52, r35 Cal. Rptr. at 363-68.

${ }^{125}$ I72 Conn. 6r5, 376 A.2d 359 (I977).

${ }^{128}$ The New Jersey Supreme Court has also struck down a school finance system which relied primarily upon local property tax funding. See Robinson v. Cahill, 62 N.J. 473,303 A.2d 273 , cert. denied, 4I4 U.S. 976 (I973). The court found a violation of state constitutional provisions requiring a "thorough and efficient system of free public schools." N.J. Const. art. VIII, § 4 , II. Similar challenges to state school financing systems have failed in a number of other states. See, e.g., Shofstall v. Hollins, Iro Ariz. 88, 515 P.2d 590 (1973); Thompson v. Engelking, 96 Idaho 793, 537 P.2d 635 (1975); Milliken v. Green, 390 Mich. 389, 212 N.W.2d 7II (r973).

${ }^{127}$ The approach taken in Robinson v. Cahill, 62 N.J. 473, 303 A.2d 273, cert. denied, 4I4 U.S. 976 (1973), which is described in note I26 supra, was slightly different. The New Jersey court relied on variations in per pupil expenditures, see 62 N.J. at 5 $55-16,303$ A.2d at 295 , rather than variations in the ability of school districts to raise revenues. As a practical matter, however, the impact of Robinson on the financing of education will be similar to that of Serrano II and Horton. See generally Grubb, The First Round of Legislative Reforms in the Post-Serrano World, 38 LAW \& Contemp. РROB. 459 (r974); Levin, Reform Through the State Courts, Strategies for Reform in Selected States, Editor's Introduction to the State Studies, 38 LAw \& ConteMr. Prob. 309, 3 IO-rI (I974); Tractenberg, Reforming School Finance Through State Constitutions: Robinson v. Cahill Points the Way, 27 RuTGers L. REv. 365 (r974).

${ }^{128}$ See 18 Cal. 3 d at 769,557 P.2d at 953 , I35 Cal. Rptr. at 369 ; 172 Conn. at $648-49,376$ A.2d at $374-75$.

${ }^{129}$ See 18 Cal. $3 \mathrm{~d}$ at $746-48,557$ P.2d at $938-39$, 135 Cal. Rptr. at $354-55$; I72 Conn. at $632-33,376$ A.2d at $367-68$. 
clearly intended to eliminate the effect of inequalities in taxable resources. Although both left the final decision on how to restructure school financing to the state legislature, they made it clear that plans which did not adjust for variations in the ability of school districts to raise funds for educational services would not pass constitutional muster. ${ }^{130}$

A variety of means exists to eliminate the impact of interdistrict tax base inequalities on educational spending. One solution would be to redraw district boundaries to ensure an equal distribution of property wealth. Another response would be the consolidation of all taxing and spending at the state level. Neither of these two solutions is without deficiencies, however. Although the first proposal protects local fiscal autonomy, it is certain to be administratively cumbersome, especially because the distribution of property wealth changes over time. The full state funding option is administratively feasible, but sacrifices local budgetary control.

There is, however, a middle road: a state funded grants-in-aid program - recently popularized as "district power equalization" (DPE) ${ }^{131}$ - which guarantees to each community a common fiscal base from which to make its budgetary choices. ${ }^{132}$ The localities use this state-determined tax base to select the tax rate which will achieve their desired level of expenditures. Then, in a typical DPE system, if their actual tax base is larger than the guaranteed base, localities contribute excess tax revenues to the state, which redistributes these funds to communities whose actual tax base is smaller than the guaranteed base. Thus, if all localities choose equal tax rates, they will be able to generate equal levels of expenditures; functional tax base equality is ensured.

The DPE proposal thus retains local decisionmaking while furthering the goal of interdistrict equity in the distribution of tax burdens and public services. There may be legal problems in implementing a DPE program, however. In Buse v. Smith, ${ }^{133}$ for example, the Wisconsin Supreme Court found that the state's recently enacted tax base equalizing system violated the state con-

${ }^{130}$ In Serrano v. Priest (Serrano II), the court held that the California legislature's actions after Serrano v. Priest (Serrano I) were insufficient to remedy the constitutional violation because local wealth remained the basis of the financing system. See I8 Cal. 3d at 746-47, 557 P.2d at 938-39, I35 Cal. Rptr. at 354-55.

${ }^{132}$ See Coons, Clune \& Sugarman, Educational Opportunity: $A$ Workable Constitutional Test for State Finance Structures, 57 CALIF. L. Rev. 305, 3I9-2I (r969). See generally Coons, Clune \& Sugarman, Private Wealte and Public Education (I970); R. Reischauer \& R. Hartman, Reformtng School Finance (I973).

132 For a more detailed discussion of DPE, see p. I7I5 infra.

${ }^{133} 74$ Wis, $2 d$ 550, 247 N.W.2d I4I (I976). 
stitution, which it interpreted to require that local taxes be spent within the district where they were raised. ${ }^{134}$ The Buse result has been criticized, however. ${ }^{135}$

In addition to requiring functional tax base equality with respect to the provision of educational services, Serrano and Horton might also be read as providing a broader mandate: the equalization of revenue-raising abilities for all major forms of local services. In effect, equal tax rates should generate equal spending for all local jurisdictions. At present, it is difficult to determine whether the courts will interpret Serrano and Horton in this way. Nonetheless, in keeping with our desire to test the full potential of judicial reform, we shall assume, for the purposes of our study, the judicial recognition of the broader mandate. ${ }^{130}$ In particular, we shall consider the equalizing impact of DPE, since that method seems a workable means of financing local services.

\section{Zoning and Open Access}

The zoning power exercised by local governments can have substantial impact on the distribution of local services and taxes. ${ }^{137}$ Because of restrictive zoning ordinances, members of

${ }^{134} I d$. at $563-79,247$ N.W.2d at $147-55$.

${ }^{135}$ See, e.g., Case Comment, State Constitutional Restrictions on School Finance Reform: Buse v. Smith, go HaRv. L. Rev. ${ }_{528}$ (1977). Buse finds impermissible a system that requires that excess revenues from one district be spent in other districts where locally generated funds are insufficient. The DPE system may be

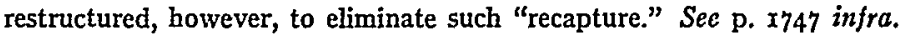

${ }^{136}$ This assumption is not entirely unreasonable. Both Horton and Robinson v. Cahill, 62 N.J. 473, 303 A.2d 273, cert. denied, 414 U.S. 976 ( 1973 ), relied specifically upon state constitutional provisions regarding education. Moreover, both Serrano $I$ and Horton found education a "fundamental interest." Other local services might also be found to involve "fundamental interests." See also Goldstein, Interdistrict Inequalities in School Financing: A Critical Analysis of Serrano v. Priest and its Progeny, I20 U. PA. L. Rev. 504, 542-44 (I972) (arguing that Serrano principle of wealth neutrality be extended to all local services).

It should be noted that the Serrano approach has been criticized by several commentators. See Levin, Foreword: Future Directions for School Finance Reform, 38 LAW \& Contemp. Prob. 293, 293-95 (1974). See also Note, A Stalistical Analysis of the School Finance Decisions: On Winning Battles and Losing Wars, 8I YALE L.J. 1303 (I972). The critics argue that because the Serrano and Horton approaches focus on inequalities in district rather than individual wealth, the problems of the poor residents of high tax base central cities are not alleviated. Furthermore, the quality of municipal services remains subject to majority will. Our analysis, see pp. I715, I734 infra, is one effort to test the validity of these criticisms.

${ }^{137}$ The magnitude of the impact of zoning remains open to question. See, e.g., U.S. Nat'c Comm'N on URban Problems, Buttding the Amertcan City I8-22 (I968); R. Babcock \& F. BossedmaAn, Exclustonary Zoninc, Land Use Regulation and Housing IN THE I970's '(1973). 
low and moderate income groups are frequently denied access to high tax base, high spending suburbs..$^{138}$ One means of improving local fiscal equity is to provide opportunities for low income families to relocate throughout the metropolitan region, thereby equalizing access to taxable wealth and to the public service levels that such wealth can provide. ${ }^{139}$ Thus, zoning reform that is metropolitan in focus - that lowers exclusionary barriers throughout a metropolitan region - may lead to a dramatic improvement in local fiscal equity.

State courts have recognized the potential of metropolitan zoning reform. In the landmark case of Southern Burlington County NAACP v. Torenship of Mt. Laurel, ${ }^{140}$ the New Jersey Supreme Court held that each community within a metropolitan area must meet its fair share of the regional housing need. ${ }^{141} \mathrm{Al}-$ though the court did not define "fair share," or identify the relevant region, ${ }^{142}$ the metropolitan focus of the opinion is clear. Despite recent New Jersey cases which have limited the scope of Mt. Laurel by exempting so-called developed communities from the fair share mandate, ${ }^{143}$ and by allowing undeveloped localities

\footnotetext{
${ }^{138}$ See, e.g., U.S. COMM'N on CIVIr RIGHTS, EQUAL OpPORTUNITy IN SUbURBIA 7 (1974); Developments, supra note 6, at 1624-35.

${ }^{139}$ See, e.g., Developments, supra note 6, at I635-59 (suggesting regional approach). The use of regionalism in exclusionary zoning cases is a recent development, althought the concept emerged in other forms of zoning litigation at an earlier date, see, e.g., Borough of Cresskill v. Borough of Dumont, 15 N.J. 238, ro4 A.2d 44I (1954). See generally Haar, Regionalism and Realism in LandUse Planning, ro5 U. PA. L. REv. 515, 526-3I (I957). Of course, some degree of meaningful reform can be achieved through progressive statutory measures limiting the practice of individual types of zoning exclusion. See, e.g., Home Builders League v. Township of Berlin, 157 N.J. Super. 586, 385 A.2d 295 (Law Div.) (invalidating minimum square feet provision based upon statutory construction), cert. granted, 77 N.J. 503, 39I A.2d 482 (1978).

${ }^{140} 67$ N.J. $\mathrm{r} 5 \mathrm{I}, 336$ A.2d $7 \mathrm{I} 3$, appeal dismissed, 423 U.S. 808 (I975).

14167 N.J. at 189,336 A.2d at 732 .

142 The problem of what constitutes a community's "fair share," as well as the related problem of what region the fair share requirement applies to, have caused much debate. See, e.g., Listokin, Fair Share Housing Distribution: Will It Open the Suburbs to Apartment Developments?, 2 REAL EsT. L.J. 739 (1974); Rose, Exchusionary Zoning and Managed Growth: Some Unresolved Issues, 6 RUT.-CAM. L.J. 689, 689-709, 7I7-20 (I975); Rubinowitz, Exclusionary Zoning: A Wrong in Search of a Remedy, 6 U. MicH. J.L. REF. 625, 652-55, 658-6I (I973); Developments, supra note 6, at I644-52. See generally Oakwood at Madison, Inc. v. Township of Madison, 72 N.J. 48I, 498-500, 524-44, 371 A.2d II92, I200-OI, I2I3-23 (I977).

${ }^{143}$ See, e.g., Pascack Ass'n v. Mayor of Washington, 74 N.J. 470,379 A.2d 6 (I977); Fobe Assocs. v. Mayor of Demarest, 74 N.J. 519, 379 A.2d 3I (1977). Placing the entire burden of meeting regional fair share on undeveloped communities seems inequitable and may result only in making them relatively less desirable than the older suburbs. See generally Buchsbaum, The Irrelevance of the "De-
} 
to set their own fair share figure, ${ }^{144}$ the regional approach has been adopted in other states, ${ }^{145}$ and has been approved by commentators. ${ }^{146}$

It is worth noting here that federal zoning law is far more narrow in scope than its state counterpart. Typically, challenges to local zoning schemes brought in federal court focus on intentional racial discrimination. ${ }^{147}$ Under federal law, inequities resulting from the metropolitan topography are irrelevant; as long as the suburban decisionmaker acts without racial animus, the community is immune from federal court supervision. ${ }^{48}$ State court attacks, on the other hand, are directly concerned with discrimination based on income and other economic factors. Thus, although the suit in Mt. Laurel was brought by minority group plaintiffs, the court's holding was premised on economic factors and was not limited to cases of racial exclusion. ${ }^{140}$ The Pennsylvania Supreme Court's opinion in Surrick v. Zoning Hearing Board, ${ }^{150}$ the most recent enunciation of that state's fair share principle, does not rely on race at all; the court clearly sought to protect all economically disadvantaged groups seeking access to growth areas in the metropolitan region. ${ }^{151}$ These cases

veloping Municipality" Concept-A Reply to Professors Rose and Levin, 5 REAL EsT. L.J. 280 (I977).

${ }^{144}$ Southern Burlington County NAACP v. Township of Mt. Laurel, I6x N.J. Super. 3I7, 39г A.2d 935 (Law Div. I978) (legislative zoning amendment allowing for 515 low income units by the year 2000 upheld).

${ }^{145}$ See, e.g., Surrick v. Zoning Hearing Bd., 476 Pa. 182, 382 A.2d to5 (1977); Berenson v. Town of New Castle, 38 N.Y.2d 102, 34 I N.E.2d 236, 378 N.Y.S.2d 672 (1975). See also Associated Home Builders v. City of Livermore, 18 Cal. $3 \mathrm{~d}$ 582, 607-09, 557 P.2d 473, 487-89, I35 Cal. Rptr. 4I, 55-57 (I976).

${ }^{140}$ See, e.g., Ackerman, The Mt. Laurel Decision: Expanding the Boundaries on Zoning Reform, 1976 U. Irx. L.F. I; Developments, supra note 6, at 1635-49. ${ }^{147}$ See, e.g., Village of Arlington Heights v. Metropolitan Hous. Dev. Corp., 429 U.S. 252 (1977). The federal courts may intervene under an effects standard, however, if suit is brought pursuant to the statutory safeguards of the Fair Housing Act of $x 968,4^{2}$ U.S.C. $\$ \S 360 I-36 x 9,363 I$ (x976). See, e.g., Metropolitan Hous. Dev. Corp. v. Village of Arlington Heights, 558 F.2d 1283 (7th Cir. 1977) (on remand) (holding that an effect standard would apply under the Fair Housing Act), cert. denied, 434 U.S. 1025 (1978).

${ }^{248}$ The exclusionary impact of zoning is relevant only if it is so overwhelming that one can presume racial discrimination. See Village of Arlington Heights v. Metropolitan Hous. Dev. Corp., 429 U.S. 252, 266 (1977). See also Kennedy Park Homes Ass'n v. City of Lackawanna, 318 F. Supp. 669 (W.D.N.Y.), afj'd, 436 F.2d 108 (2d Cir. I970), cert. denied, 401 U.S. Ioro (197I). Some local zoning is sufficiently blatant to create a strong case for the existence of racial discrimination. See Resident Advisory Bd. v. Rizzo, 564 F.2d 126, 140-45 (3d Cir. r977), cert. denied, 435 U.S. 908 (1978).

${ }^{149} 67$ N.J. at 159,336 A.2d at 717 .

${ }^{150} 476 \mathrm{~Pa}$. I82, 382 A.2d I05 (I977).

151 Id. at 194,382 A.2d at IIr. 
are intended to engender wide-reaching economic reform; for example, the $M t$. Laurel court seems to have been moved by a vision of a "new" metropolitan New Jersey, with an entirely different economic composition.

As yet, no state court has devised a remedy which ensures that each community within a metropolitan area will provide its fair share of regional housing needs. In Oakwood at Madison, Inc. v. Township of Madison, ${ }^{152}$ for example, the leading New Jersey case on remedies, the court simply required that all communities provide housing opportunities for the poor; ${ }^{153}$ localities need do no more than adopt zoning ordinances which will promote the least costly housing possible consistent with minimum standards of safety and health. ${ }^{154}$ Thus, under Madison, as long as the system holds the promise of equal access, the courts need not consider whether low cost housing is actually built. ${ }^{155}$ It is not at all clear, however, that such construction will in fact take place, especially because of the likelihood that recalcitrant communities will engage in subterfuge and delay. ${ }^{156}$ To a certain extent, the failure to develop meaningful remedies can be attributed to the desire to preserve the separation of judicial and legislative powers. ${ }^{157}$ The development of effective remedies has also been hindered by restrictive applications of the fair share principle. ${ }^{158}$

In accordance with our desire to test the full potential of judicial reform, we shall assume that as a result of a $M t$. Laureltype reform, each community will reserve an area sufficient to accommodate its fair share of low cost housing. Thus, if there are developers willing to construct low cost housing and low income families desiring to relocate in the suburbs, each com-

15272 N.J. 48I, $37 x$ A.2d IIg2 (I977).

${ }^{153}$ Id. at 512-I4, $37 \mathrm{x} \mathrm{A} .2 \mathrm{~d}$ at $\times 206-08$. See generally Developments, supra note 6 , at $1694-708$.

15472 N.J. at 512-14, 371 A.2d at I206-08.

${ }^{155}$ Cf. Montgomery Assocs. v. Township of Montgomery, I49 N.J. Super. 536, 374 A.2d 86 (Law Div. I977) (even though community's population of low income persons remained small, claim based upon argument that community had failed to meet its fair share of regional housing needs was dismissed, since community had created zone of land suitable for low income housing construction), aff'd, r60 N.J. Super. 219, 389 A.2d 503 (App. Div. 1978).

${ }^{156}$ See, e.g., Mytelka \& Mytelka, Exclusionary Zoning: A Consideration of Remedies, † Seton Hatr L. Rev. I (1975); Mallach, Do Lawsuits Build Housing?: The Implications of Exclusionary Zoning Litigation, 6 RUT.-CAM. L.J. 653 (I975).

${ }^{157}$ See, e.g., City of Richmond v. Randall, 215 Va. 506, 2II S.E.2d 56 (I975); Southern Burlington County NAACP v. Township of Mt. Laurel, I6I N.J. Super. 3I7, 39I A.2d 935 (Law Div. I978). See generally Note, The Inadequacy of Judicial Remedies in Cases of Exclusionary Zoning, 74 MICE. L. REv. 760, 774-79 ( $\mathrm{x} 976)$.

${ }^{158}$ See pp. I709-10 supra. 
munity (without reference to stage of development) will have a low income population equal to the metropolitan average.

\section{E. Summation}

The cases described here reveal four possible strategies for judicial reform of local public finance. The first strategy requires the equitable distribution of municipal service expenditures within a community. The second seeks to ensure that the rate at which residential property is assessed for tax purposes is uniform throughout the jurisdiction. The third would attempt to eliminate variations in expenditure levels among communities caused by differences in revenue-raising abilities. The fourth would seek to dismantle exclusionary zoning barriers, by insisting that each locality meet its fair share of regional housing needs. On their face, these strategies seem quite appealing. The urban economy is highly fluid, however. Thus, until we have determined how families and local governments will respond to these reforms, we should be reluctant to assume that they will in fact lead to greater fiscal equity.

\section{The Maximal Gains}

While the cases reviewed have been decided in a variety of state and federal courts and thus no metropolitan area is currently bound to satisfy the requirements of all, it is instructive to ask what the equity gains might be if the local governments in our prototype economy were subject to each of the four types of judicial mandate for local fiscal reform and the four strategies had their fullest possible effect. In so doing, one gains important insights into the potential effect of judicial activism on urban fiscal inequities. In Part IV, we consider reasons why the four approaches may not reach their full theoretical potential. Throughout this Part, we will be referring to the status quo model presented in Part I as a baseline for comparison. Tables III and IV summarize our results.

The Hawkins principle requires that central city spending be equalized across all income classes. After such an equalization, spending within the city totals $\$ \mathrm{I}, 654$ per family. As there is little evidence to indicate any systematic discrimination in the spending patterns of the suburbs, ${ }^{159}$ no changes from the status quo are anticipated in suburban spending. The result is that $a$, the income elasticity of local expenditures, falls to 0.00 within the

${ }^{159}$ See McDonald, The Distribution and Production of Education: A Disaggregate Analysis 63-94 ( 1978 ) (unpublished $\mathrm{Ph} . \mathrm{D}$. thesis on file with the authors). 
TABLE III

Maximal Regional ImpaCt of EXPENDiture Reform

(Spending in \$ per family)

\begin{tabular}{|c|c|c|c|c|c|}
\hline $\begin{array}{l}\text { Family } \\
\text { Income } \\
\text { (r) }\end{array}$ & $\begin{array}{c}\text { Status } \\
\text { Quo } \\
\text { (2) }\end{array}$ & $\begin{array}{l}\text { Within City } \\
\text { Equity } \\
\text { (3) }\end{array}$ & $\begin{array}{c}\text { Tax Base } \\
\text { Equality } \\
\text { (4) }\end{array}$ & $\begin{array}{c}\text { Open } \\
\text { Access } \\
\quad(5)\end{array}$ & $\begin{array}{c}\text { Joint } \\
\text { Enforcement } \\
(6)\end{array}$ \\
\hline 5,000 & 986 & I,I 59 & $I, 237$ & $I, I 86$ & 1,378 \\
\hline 10,000 & $I, I 32$ & $I, I 50$ & $I, 360$ & $I, I 32$ & 1,378 \\
\hline I5,000 & 1,262 & $I, 209$ & $I, 423$ & $I, 262$ & 1,372 \\
\hline 20,000 & $\mathrm{I}, 567$ & $I, 47 \mathrm{I}$ & $I, 466$ & $I, 567$ & $I, 375$ \\
\hline 25,000 & $x, 749$ & I, 636 & $\mathrm{I}, 5 \mathrm{IO}$ & $I, 748$ & $I, 385$ \\
\hline \multicolumn{6}{|c|}{$\begin{array}{c}a \\
\text { (expenditure } \\
\text { elasticity) } \\
\end{array}$} \\
\hline City & 0.250 & 0.000 & 0.250 & 0.250 & 0.000 \\
\hline Suburbs & 0.650 & 0.650 & 0.069 & 0.290 & 0.022 \\
\hline Overall & 0.350 & 0.210 & 0.125 & 0.280 & 0.000 \\
\hline
\end{tabular}

TABLE IV

Maximal Regional Impact of Tax Reforms * (Taxes in \$ per family)

\begin{tabular}{|c|c|c|c|c|c|c|c|c|}
\hline \multirow[b]{2}{*}{$\begin{array}{l}\text { Family } \\
\text { Income } \\
\text { (I) }\end{array}$} & \multicolumn{2}{|c|}{ Status Quo } & \multicolumn{2}{|c|}{ Assessment Equity } & \multirow{2}{*}{$\begin{array}{c}\text { Tax Base } \\
\text { Equality } \\
\text { (6) }\end{array}$} & \multicolumn{2}{|c|}{ Open Access } & \multirow{2}{*}{$\begin{array}{r}\begin{array}{r}\text { Joint } \\
\text { Enfoirce } \\
\text { ment }\end{array} \\
\\
(9)\end{array}$} \\
\hline & $\begin{array}{c}\text { Direct } \\
\text { Cost } \\
\text { (2) }\end{array}$ & $\begin{array}{c}\text { Net Fiscal } \\
\text { Cost } \\
\text { (3) }\end{array}$ & $\begin{array}{c}\text { Direct } \\
\text { Cost } \\
(4)\end{array}$ & $\begin{array}{c}\text { Net Fiscal } \\
\text { Cost } \\
\text { (5) }\end{array}$ & & $\begin{array}{c}\text { Direct } \\
\text { Cost } \\
(7)\end{array}$ & $\begin{array}{c}\text { Net Fiscal } \\
\text { Cost } \\
\text { (8) }\end{array}$ & \\
\hline 5,000 & 636 & 482 & 599 & 443 & 380 & 374 & 286 & 336 \\
\hline 10,000 & 863 & $54 \mathrm{I}$ & 835 & $5 \mathrm{I}_{4}$ & 700 & 863 & $54 I$ & 662 \\
\hline I5,000 & $I, 005$ & 587 & 998 & 576 & $I$, OI2 & $I, 005$ & 587 & 994 \\
\hline 20,000 & $I, I 3 I$ & $I, 078$ & $I, I 40$ & $I, 086$ & $I, 322$ & $I, I 3 I$ & $\mathrm{I}, 078$ & $I, 3 \mathbf{2 3}$ \\
\hline 25,000 & $I, 210$ & $\mathrm{I}, 428$ & $I, 239$ & $I, 45^{8}$ & $I, 632$ & $I, 210$ & $I, 428$ & $\mathrm{I}, 657$ \\
\hline \multicolumn{9}{|c|}{$\begin{array}{c}{ }^{\epsilon} \\
\text { (tax } \\
\text { elasticity) } \\
\end{array}$} \\
\hline City & r.oII & I.OII & I.OOO & I.OII & I.OII & I.OII & I.OII & 1.000 \\
\hline Suburbs & I.IOO & I.IOO & I.IOO & I.060 & r.000 & 1.024 & I.000 & 1.000 \\
\hline Overall & I.054 & I.027 & 1.048 & I.O2I & I.006 & 1.020 & 1.006 & 1.000 \\
\hline
\end{tabular}

* All calculations based on a common $\$ 1,300$ per family local public spending level. Tax rates against family income (not shown) can be calculated by dividing tax costs by family income. 
city to reflect the assumption of equal expenditures. For the entire metropolis, $a$ falls from 0.35 to $0.2 \mathrm{I}$, which, while still pro-rich, represents a substantial improvement in spending equity. The remaining inequalities are a function of the ability of suburbs with high tax bases to fund higher levels of service at relatively low prices.

Like the Hawkins strategy, the Hellerstein approach, which requires intrajurisdictional taxpayer equity, will impact primarily on the larger central cities since it is there where assessment variations are most pronounced. ${ }^{160}$ Though some assessment variations exist in the suburbs, the high mobility of suburban families and active local assessment appeal processes limit the extent to which one community can "exploit" an income class through assessment variations. ${ }^{161}$ The effect within the central city is to equalize for all city residents direct tax costs expressed as a fraction of property value. With an average tax base of $\$ 48,800$ per family in our prototype city, the locality requires a tax rate of 0.026 to fund the standard $\$ \mathrm{I}, 300$ level of services. ${ }^{162}$ With assessment equity all families would pay that tax rate. As before, if we assume that the ratio of the value of family residential property to family income is 2.5 to $r,{ }^{163}$ we can estimate each family's property tax bill in the central city as a function of family income. The property tax bill equals the local tax rate (0.026) multiplied by the value of the family's property $(2.5 \times$ income $)$. This results in a ratio of tax cost to income of $0.068(=0.026 \times 2.5)$ for all central city families. Assessment equity, of course, turns a regressive direct tax structure into a proportional one. Thus, the equity tax statistic, $\epsilon$, for the city falls from I.OII to I.000 (Table IV, column 4).

The improved central city performance also results in improved regional tax equity. Both the average direct tax costs and the average net fiscal costs (which reflect adjustments for changes in land value) show a substantial gain for the lower income groups as they pay less taxes under equalized assessments (Table IV, columns 4 and 5). Of course, this lowered tax cost to the poor is balanced by increased direct tax costs for those with incomes over $\$ 5$,000 per year. The combined effect is to reduce the regional tax equity measure, $\epsilon$, from 1.054 to $\mathrm{r} .048$ for direct tax costs and from $I .027$ to $x .02 I$ for net fiscal costs (Table IV, col-

${ }^{160}$ See p. I680 supra.

${ }^{161}$ See, e.g., Hamilton, The Impact of Zoning and Property Taxes on Urban Structure and Housing Markets (I972) (unpublished $\mathrm{Ph} . \mathrm{D}$. thesis on file with the authors). 
umns 2-5). Again, the main source of the remaining tax inequity is the tax base disparities among communities.

The effect of tax base disparities is the target of the Serrano strategy. As noted above, ${ }^{164}$ a district power equalization (DPE) system is the most likely system to be adopted as a result of the Serrano mandate. Under the simplest form of this system, a community selects its preferred spending level and tax rate $(r)$ as if its taxable base per family were equal to a predetermined and uniform hypothetical tax base $\left(B^{*}\right)$. The state, through grantsin-aid, promises to fill the gap between what the jurisdiction raises from the community's actual market value tax base per family $(M V B)$, and what the jurisdiction would have raised if its tax base per family equaled the hypothetical target base figure $B^{*}$. State aid per family thus equals $r\left(B^{*}-M V B\right),{ }^{165}$ since the quantity $\left(B^{*}-M V B\right)$ represents the community's shortfall in its actual tax base per family over the state target. Note that a jurisdiction which has a market value base $(M V B)$ less than the hypothetical uniform base $\left(B^{*}\right)$ receives a positive level of aid, while a community whose actual base is greater than the uniform base receives negative aid - it will pay the excess to the state for redistribution to the poorer districts to finance their chosen levels of spending.

Unlike the Hawkins and Hellerstein strategies, the Serrano approach involves changes in both taxes and expenditures. For our prototype metropolis, we select $\$ 55,000$ per family, the mean tax base per family within the entire region, as the target tax base $\left(B^{*}\right)$. This figure allows the DPE plan approximately to break even, since the negative aid received from rich jurisdictions just about balances the positive subsidies paid to poor communities. ${ }^{166}$

On the expenditure side, the initial impact of Serrano is to promote increased equality. Assuming that poor tax base com-

${ }^{104}$ See p. I707 supra.

${ }^{165}$ Since $r$ is set to finance the preferred budget when the community acts as if its true base were $B^{*}, r=T / B^{*}$, where $T$ equals the actual taxes per family. Thus, we can rewrite the state-to-local aid formula as: Aid per family $=\left(T / B^{*}\right)$ $\left(B^{*}-M V B\right)=\left[\mathrm{I}-\left(M V B / B^{*}\right)\right](T)$. A study by Feldstein, Wealth Neutrality and Local Choice in Public Education, 65 AM. Econ. REv. 75 (I975), examined the conditions necessary to ensure that local spending following DPE is truly independent of local taxable wealth. Feldstein did not find these conditions to hold within his sample of Massachusetts school districts. We have decided not to incorporate Feldstein's adjustments to the DPE formula in our analysis. Work by Inman, Optimal Fiscal Reform of Metropolitan Schools: Some Simulation Results, 68 AMr. EcoN. REv. I07 (I978), indicates that only in extreme cases do these adjustments dominate the equity performance of the DPE plan described in text. Thus, the formula used here is as pro-equalizing as any DPE-type plan likely to be adopted.

${ }^{106} \mathrm{Cf}$. Inman, supra note $\mathrm{I65}$, at II7 (also showing that this target base is the equity maximizing base for the region). 
munities also tend to be low spending areas because they have difficulty raising funds, ${ }^{107}$ the sudden boost in tax base created by the DPE plan will permit increased spending; the DPE plan lowers the costs to residents per dollar of local spending and, as tax price falls, local spending predictably rises. Conversely, residents in wealthy communities are faced with a decline in tax base which causes an increase in tax cost per dollar of local spending. As a result, these areas will cut back on local spending.

Full spending equality, however, is not achieved. Average family income, the other main determinant of local spending decisions, still varies across political boundaries. Rich communities, even if prevented from taking advantage of favorable tax base conditions, will still demand higher levels of services than their lower income counterparts for any given tax cost. Further, under DPE the central city may still discriminate across income classes in disbursing city services. Nonetheless, tax base equalization does have a potentially substantial effect on spending equity. New spending levels based on an assured tax base, $B^{*}$, of $\$ 55,000$ per family were calculated for the central city and for each of the five types of suburban communities. ${ }^{168}$ The mean level of spending within the city falls slightly because the city's original base of $\$ 58,000$ exceeds $B^{*}$, thus causing a higher tax price and an overall lower demand for services. These dollars, however, continue to be distributed unequally within the city. The rich are still favored, and our measure of spending equity $(\alpha)$ for the central city remains at 0.25 (Table III, column 4). But under Serrano, spending equity within the suburbs is substantially improved. Aid induces more than a $100 \%$ spending increase in the very poorest suburbs (from $\$ 476$ per family to $\$ \mathrm{r}$ r 46 per family) and still substantial $35 \%$ and $70 \%$ increases for the middle and lower middle class suburbs respectively. The losers under the Serrano mandate are the residents in the suburbs with average incomes of $\$ 20,000$ and $\$ 25,000$ where reduced tax bases cause spending levels to decline by $8 \%$ and $20 \%$ respectively. Our spending equity measure for the suburbs falls from its original

${ }^{167}$ See pp. 1671-89 supra.

${ }^{168}$ New spending levels for suburbs following base equalization aid were computed by redefining the local tax price $(\pi)$ as $b / B^{*}$, where $b$ is 2.5 times income as before and $B^{*}$ equals $\$ 55,000$. The new tax price was then substituted into the suburban community demand equation for local services, $G=\mathbf{x} .5657^{0.07}$ $\pi^{-0.0}$, see note 35 supra. The new central city spending level was computed using the new tax price $(\pi)$ for the median income city resident, also based on $B^{*}$ equal to $\$ 55,000$. The new level of aggregate spending was then allocated across income groups within the city according to the formula, $G=153.81^{0.25}$, where the new constant term, 153.8 , reflects the slight fall in aggregate city spending due to the loss in state aid with an equalizing tax base $\left(B^{*}=\$ 55,000\right)$ less than the city's tax base measured at market value ( $\$ 58,000$ per family). 
value of 0.65 to a low of 0.069 if the observed adjustments hold. For the region as a whole, the suburban gains translate into a significant regional improvement; $a$ declines from 0.35 before a Serrano-type reform to a low of 0.125 .

Serrano reforms promise similar gains in taxpayer equity, again resulting from the improvement in equity in the suburbs. Since assessment practices are unaffected under a Serrano-only strategy, the distribution of the intracity tax burdens remains regressive. The removal of tax base inequities within the suburbs, however, turns the previousiy regressive suburban tax system into a proportional one. The value of our tax equity measure $(\epsilon)$ for direct tax costs falls from its original suburban value of I.Io to I.00 (Table IV, column 6). ${ }^{169}$

In addition, there will be a one-time adjustment in suburban land values favoring the residents of low tax base communities. Before, homeowners were willing to pay a premium for the beneficial tax bases found in the suburbs rich in commercial and industrial property. With the removal of tax base disparities, the residential land price premium associated with those disparities should disappear. Land values will fall in the rich suburban communities and rise in the relatively poor suburbs and the central city. We assume that land values will change just enough to offset the original premium detailed in Table II. Residents in rich suburbs will see the value of their 0.6 -acre average plots decline by $\$ 7,040$ dollars, equivalent to an annual income loss of $\$ 704$ amortized at the rate of Io\% per year. Residents in the upper middle class suburbs (incomes around $\$ 20,000$ ) lose the equivalent of $\$ 226$ per year as their 0.4 -acre average plots fall in value

${ }^{169}$ For suburban communities, the new direct tax cost needed to finance our common budget of $\$ \mathrm{~T}, 300$ per family is computed simply as the new local tax rate equals net local expenditures per family $(\$ \mathrm{I}, 300-$ Aid $)$ divided by the assessed taxable base per family $(B)$, where $A i d$ is computed via the DPE formula, see note $I 65$ supra, and the assessed taxable base per family (B) continues to allow for the favorable assessment afforded commercial property, see pp. 168I-83 supra. Algebraically, Aid $=[x-(M V B / \$ 55,000)](\$ \mathrm{x}, 3 \infty 0)$, and $r$ $=(\$ I, 300-A i d) / B$, where $M V B$ equals the sum of the per family market values of residential and commercial-industrial property (recall that $M V C I=\$ 2,000+$ $0.9 I$, note 28 supra, and $B=\$ \mathrm{I}, 300+3,085 I$, note 35 supra). Given suburban income levels we can solve for $r$. For each suburb, $r=0.026$. This rate times individual family tax bases (b) gives the suburban direct tax cost reported in Table IV.

For the central city, we first calculate the uniform city tax rate needed to finance expenditures plus aid. As $M V B$ for the city is $\$ 58,000$ per family, note 38 supra, and exceeds the target base of $\$ 55,000$ per family, aid will be a minus $\$ 7 \mathrm{I}$ per family. Thus, city taxes must raise $\$ 1,371$ per family to support the $\$ 1,300$ per family budget. This means a small rise in the uniform local tax rate from its original value of 0.026 to a new, post-aid value of 0.028 . 
by $\$ 2,260$. The residents of lower income suburbs enjoy a windfall profit which translates into annual income gains of $\$ 180, \$ 362$, and $\$ 427$ for the poor, lower middle class, and middle class residents respectively. Central city residents also gain. The rich, who own more land than the others, enjoy a $\$ 687$ per year windfall, larger than that received by their poorer counterparts. With tax base equalization, direct tax and net fiscal costs are thus equalized, since no differentials in land value induced by variations in the tax base remain. The new region-wide value of $\epsilon$ measured for direct tax costs now equals r.006 (Table IV, column 6 ). The remaining regressivity is due to the city's unconstrained assessment practices. Overall, the Serrano reform appears to be a very promising strategy for achieving local fiscal equity due to its equalizing effect on the suburbs.

The prospects that zoning reform under $M t$. Laurel will create improvements in local fiscal equity are similarly bright. As discussed above, the spirit of $M t$. Laurel seems to require that each suburb with available residential land zone that land for low and moderate income housing so that, were the locality fully developed, it would have a population with at least the same share of poor families as the region as a whole. For example, since $\mathrm{r}_{4} \%$ of the population of our typical region have incomes of $\$ 5,000$ or less, each suburb would be required to allocate residential land for low income housing so that at least $\mathrm{I} 4 \%$ of its own future population at full development would have incomes of $\$ 5,000$ or below. Under the assumptions ( $I$ ) that the new housing for the poor within the suburbs will have the same density as the housing in which they live now (roughly 20 families per acre in townhouses or apartment complexes; (2) that all suburbs have sufficient open space to accommodate housing for the target figure; and (3) that the poor will in fact relocate in the middle class and rich suburbs, ${ }^{170}$ it is possible to calculate the post-Mt. Laurel distribution of taxes and spending by income class associated with the new pattern of family location (see Tables III and IV).

The new suburban spending levels are calculated under the assumption that the very low income families will receive the spending levels currently available in the suburbs. In allocating families in our model, we have first placed all the suburban poor into higher income suburbs so that the poorest suburbs composed of families with incomes of $\$ 5,000$ will disappear. ${ }^{171}$ The new

${ }^{170}$ For the validity of these assumptions, see pp. $1721-47$ infra.

${ }^{171}$ By first removing the very poor from the low spending, high tax suburbs and then allocating the remaining suburban lots to the central city poor who suffer less fiscal discrimination, we maximize the potential gains in equity from the judicial reform and thus err, if at all, in favor of increased equity. 
average spending level received by families with incomes of $\$ 5,000$ in the suburbs is now $\$ 1,067$ per year, compared to the original $\$ 476$ per year. After the suburban poor are placed, there is still room in the wealthier suburbs to absorb roughly $30 \%$ of the city poor as well. They too will receive an average suburban spending level of $\$ \mathrm{I}, 067$ per family per year.

With relocation from the city, the fraction of the region's poor who live within the city decreases from the original level of $58 \%$ to $4 \mathrm{I} \%$. The new region-wide average spending for the poor is now $\$ I, I 86$, a $\$ 200$ increase from the original regional average (Table III, column 5). If there are no further fiscal adjustments associated with the relocation, all other city spending remains the same. The value of $a$ for suburban areas falls from the original level of 0.65 to 0.29 , an adjustment that translates into a decline in $a$ for the entire region from 0.35 to 0.28 (Table III, column 5). Thus, a Mt. Laurel strategy can have a significant impact on spending equity.

Tax equity is improved as well. As poor families are relocated in wealthy suburbs, their direct tax and net fiscal costs fall as they now receive the benefits of commercial and industrial wealth. The new average tax costs, calculated for our common $\$ \mathrm{I}, 300$ budget for the families with $\$ 5000$ in income placed in the rich and middle income suburbs, are $\$ 374$ in direct tax costs and $\$ 286$ in net fiscal costs (Table IV, columns 7,8 ). These are calculated on the assumption that the poor families pay the same property tax rates as the other families in their new community. But because the poor live in low cost housing, they pay that equal tax rate against a smaller individual tax base. Since direct tax costs and net fiscal costs fall for the suburban poor while the tax costs for all other residents remain the same, tax equity is improved. In the region, the value of $\epsilon$ falls from the previous value of 1.054 to 1.020 for direct costs and from the original value of 1.027 to $I .006$ for net fiscal costs (Table IV, columns $7,8)$. Thus, the potential gains from a $M t$. Laurel strategy are quite substantial.

Figure 3 provides a graphic summary of the potential gains offered by each of the four judicial reforms, measured in terms of their effects in reducing the spending and tax equity statistics. Point $L(a=0.35, \epsilon=1.027)$ in Figure 3 is the status quo equity performance of the local public economy, corresponding to point $L$ in Figure 2. Each line of judicial attack has the potential to push the metropolitan economy towards a more equitable service or tax position. The Hawkins strategy, for example, can take $\mathrm{L}$ to point $\mathrm{I}$ with increased expenditure equity ( $a$ falls to $0.2 \mathrm{I}$ ), but there is no improvement in tax equity. Hellerstein 


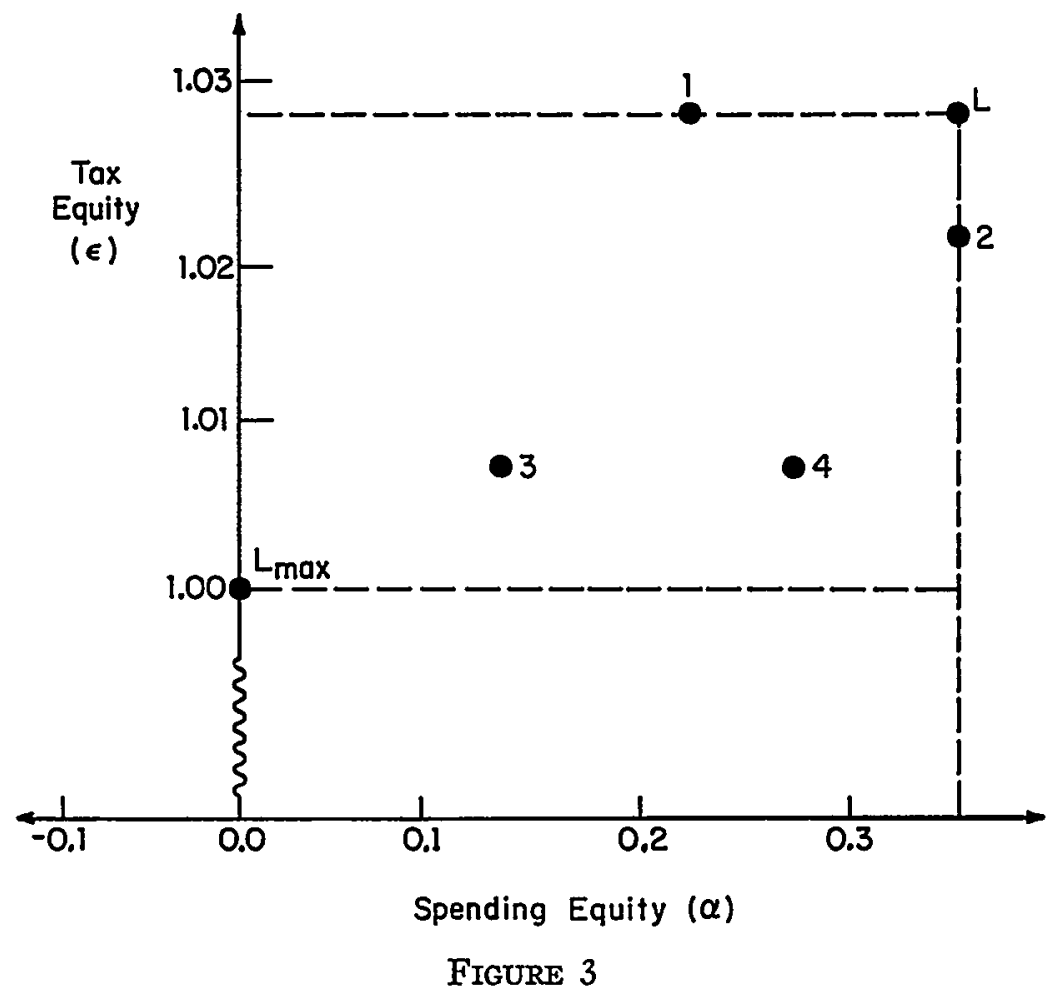

(point 2) improves tax performance $(\epsilon=\mathrm{r} .02 \mathrm{I}$ ), but spending equity is unaffected. The Serrano (point 3: $\alpha=0.125, \epsilon=$ I.006) and Mt. Laurel (point 4: $a=0.28, \epsilon=$ r.006) reforms can, by themselves, lead to substantial improvements in both spending and tax equity. If only one judicial strategy could be pursued, attacking suburban exclusivity through a broadened Serrano or Mt. Laurel holding would have the most promise for equity gains.

What happens if all four judicial constraints are imposed at once? The result, summarized in Tables III and IV, suggests that to some degree the constraints reinforce each other to give an aggregate, potential equity improvement greater than that possible with any individual approach. Because all city families receive the same level of public services under Hawkins, the city value of $a$ is 0.00 under joint enforcement. The level of spending within the city - a function only of the demand for services given the Serrano tax base reform - is now $\$ 1,576$. The suburban spending levels by income class correspond to the figures determined under the Serrano-only mandate, except for the families with incomes of only $\$ 5,000$. For that group, the Mt. Laurel decision results in a spending level greater than that achieved in 
Serrano alone. Their average spending level rises from $\$ \mathrm{I}, \mathrm{I} 46$ per family with tax base equalization alone to $\$ I, 24 \mathrm{I}$ per family with both tax base equalization and relocation. Open access also provides extra benefits to those central city families who relocate. As a result, the suburban $a$ now falls to 0.022 under joint enforcement (Table III, column 6). Overall, regional average spending shows a nearly equal distribution by income class. The very rich still get $\$ 7$ to $\$ \mathrm{I}_{3}$ more per family than the poor or middle class, but this difference is trivial. Our measure of regional spending equity, $a$, falls to 0.00 .

The potential gains in tax equity with joint enforcement also augment the potential gains associated with the enforcement of any single judicial strategy. Table IV summarizes the new tax distribution required to support the common $\$ I, 300$ per family spending level. Within the suburbs the tax distribution across income classes corresponds to that achieved with Serrano alone. Open access makes no difference here as all suburban families pay the same tax rate for local services no matter where they live. Because of assessment equality, all families within the city now pay a common tax rate against income (0.066) to support the common service package. As a result, the tax structure is potentially proportional $(\epsilon=$ I.000) (Table IV, column 9).

In summary, the point $\mathrm{L}_{\max }$ in Figure $3(a=0.00, \epsilon=\mathrm{I} .00)$ is the outer bound on equity which a full scale judicial attack against local fiscal inequity could hope to achieve. Complete taxpayer neutrality $(\epsilon=I .00)$ requires tax base equality plus assessment equity. Complete spending neutrality $(a=0.00)$ requires expenditure equity within the city, tax base equality, and open access. This potential improvement in equality is substantial, but not radical. Even if the judicial strategies are liberally interpreted and effectively enforced, the best that can be expected is a level of equity comparable to that presently observed for most state governments. ${ }^{172}$ But even this modest goal is not assured. At this point, all that has been detailed is the potential offered by extrapolations from the new case law. Predicting whether this theoretical potential can in fact be achieved is the second important step.

\section{The Promise Fulfilled?}

The predictions made in Part III dealt only with the effects of judicial reform within a passive urban economy. That the reforms' full potential will be achieved is far from obvious. In the real world, firms, households, and governments are permitted to react to judicially imposed changes in the economic environment. 
It is therefore important to test the promise of reform against the realities of this dynamic urban economy. Tables $V$ and VI summarize the conclusions of this test.

\section{TABLE V}

Predicted Regtonal Expenditures

(Spending in \$ per family)

\begin{tabular}{|c|c|c|c|c|}
\hline $\begin{array}{l}\text { Family Income } \\
\text { (I) }\end{array}$ & $\begin{array}{c}\text { Assessment Equity } \\
\text { (2) }\end{array}$ & $\begin{array}{c}\text { Tax Base Equalily } \\
\text { (3) }\end{array}$ & $\begin{array}{c}\text { Open Access } \\
\text { (4) }\end{array}$ & $\begin{array}{c}\text { Joint } \\
\text { Enforcement } \\
\text { (5) }\end{array}$ \\
\hline 5,000 & $I, 004$ & I,I39 & $I, I 38$ & 1,265 \\
\hline I0,000 & $\mathrm{I}, \mathrm{I} 54$ & $I, 329$ & $I, I 56$ & 1,325 \\
\hline I 5,000 & $I, 279$ & $I, 383$ & $I, 290$ & $I, 332$ \\
\hline 20,000 & I, 587 & $r, 497$ & $r, 426$ & 1,406 \\
\hline 25,000 & 1,808 & $\mathrm{I}, 578$ & $I, 568$ & $x, 45^{2}$ \\
\hline \multicolumn{5}{|l|}{$\begin{array}{c}a \\
\text { (expenditure } \\
\text { elasticity) }\end{array}$} \\
\hline City & 0.27 & 0.25 & 0.25 & 0.00 \\
\hline Suburbs & 0.65 & 0.26 & 0.20 & 0.18 \\
\hline Overall & 0.36 & $0.2 I$ & $0.2 I$ & 0.08 \\
\hline
\end{tabular}

\section{TABLE VI}

Predicted Regtonal Taxes *

(Taxes in \$ per family)

\begin{tabular}{|c|c|c|c|c|c|c|}
\hline \multirow[b]{2}{*}{$\begin{array}{l}\text { Family } \\
\text { Income } \\
\text { (I) }\end{array}$} & \multicolumn{2}{|c|}{ Expenditure Equity } & \multirow{2}{*}{$\begin{array}{c}\text { Tax Base } \\
\text { Equality } \\
\\
\text { (4) }\end{array}$} & \multicolumn{2}{|c|}{ Open Access } & \multirow{2}{*}{$\begin{array}{c}\text { Joint } \\
\text { Enforcement } \\
\\
(\eta)\end{array}$} \\
\hline & $\begin{array}{c}\text { Direct } \\
\text { Cost } \\
\text { (2) }\end{array}$ & $\begin{array}{c}\text { Fiscal } \\
\text { Cost } \\
\text { (3) }\end{array}$ & & $\begin{array}{c}\text { Direct } \\
\text { Cost } \\
(5)\end{array}$ & $\begin{array}{c}\text { Fiscal } \\
\text { Cost } \\
\text { (6) }\end{array}$ & \\
\hline 5,000 & 724 & $5^{69}$ & 392 & $3^{85}$ & 329 & 324 \\
\hline I0,000 & 927 & 605 & 710 & 734 & 605 & 672 \\
\hline I5,000 & 1,005 & 587 & I,OI3 & $x, 096$ & 677 & 995 \\
\hline 20,000 & $I, 043$ & 989 & $I, I 92$ & $I, 2 I 2$ & I,I55 & $I, I 92$ \\
\hline 25,000 & $I, 082$ & $I, 299$ & $I, 4 \mathrm{I} 2$ & 1,309 & $I, 525$ & $I, 43 I$ \\
\hline \multicolumn{7}{|c|}{$\begin{array}{l}\epsilon \\
\text { (tax elasticity) } \\
\end{array}$} \\
\hline$\overline{C i t y}$ & I.043 & $\mathrm{r} .048$ & I.OII & I.OII & I.OII I & 1.000 \\
\hline Suburbs & I.IOO & 1.060 & 1.014 & 1.021 & x.006 & 1.006 \\
\hline Overall & I.O7I & 1.043 & I.OI3 & I.013 & 1.005 & 1.002 \\
\hline
\end{tabular}

* All tax calculations based on a common $\$ \mathbf{r}, 300$ per family local public spending level. 


\section{A. Fiscal Equity Within the City: Hawkins and Hellerstein}

The constraints of an expanded Hawkins or Hellerstein ruling will be most strongly felt within the large central cities of our metropolitan economies. As argued in Part $I$, central cities have an incentive to pursue a discriminatory policy against the poor. To protect the tax base advantages of having rich and upper middle class residents living within the city, the city government must offer fiscal favors to the rich to discourage their exit to the suburbs. Equal spending and equal assessment requirements thwart this strategy; the city is constrained in its ability to favor the wealthy. But even so limited, the city may have alternative ways to minimize the risk resulting from the mobility of high income families. If not, and exit occurs, this new dispersal itself may threaten to make the region's distribution of services and taxes less equitable.

With judicial acceptance and enforcement of a Harkins mandate for equal public service expenditures, the central city loses one of its most important tools for protecting the interests of its wealthier residents. With equal spending across all income classes now required, the city's rich lose and the city's poor gain relative to the pre-reform allocation of public services. Now those rich who were just indifferent between city and suburban living may find it advantageous to relocate. Further, the new distribution of city services may also cause some net in-migration of poor and lower middle class families from the suburbs into the city.

The loss of high income, high tax base families to the suburbs coupled with an increase in low income, low tax base households will have a negative impact on the value of the city's residential tax base. Furthermore, the decrease in the number of wealthy citizens may create a less favorable neighborhood environment within the city thus reinforcing the downward pressure on property values.

Faced with the prospect of this loss of tax base, city officials are likely to adopt new pro-rich policies. Specifically, what the courts have reallocated on the spending side of the ledger, the city can give back on the taxing side through favorable reassessments. If city officials view the losses to the rich as equal to their actual dollar spending losses, then the task of protecting the city tax base will require the city to "make good" these imposed dollar losses on the tax side. For example, by comparing the status quo spending levels in Table I to the Hawkins equal spending levels of $\$ \mathrm{r}, 654$ per family, the rich ( $\$ 25,000$ income class) and upper middle classes $(\$ 20,000$ income class) will lose $\$ 367(=\$ 2,02 \mathrm{x}-$ $I, 654)$ and $\$ 264(=\$ 1,9 I 8-I, 654)$ per year in services respec- 
tively. To avoid the possibility of out-migration by rich and middle income families, the city can respond by varying assessments to offset these spending losses. As taxes are reduced for the rich, they must be increased for the others, if the city is to continue to support the overall preferred spending level. The result is an increase in tax inequality. While these adjustments may take time, perhaps as long as five to ten years, the effect is substantial and, once in place, permanent. The court must be sensitive to such lasting changes.

To estimate how serious the decline in tax equity might be, we have recalculated Table I (the status quo) under the assumption that the city realigns its assessment pattern to keep the net dollar fiscal position (expenditures received minus taxes paid) of the $\$ 25,000$ and $\$ 20,000$ families equal to their pre-reform levels. To keep the per family dollar fiscal surpluses of the two upper income groups constant, their taxes must be reduced by $\$ 367$ per family and $\$ 264$ per family respectively. We assume that the politically dominant middle class ( $\$$ I 2,000 to $\$$ I 5,000 families) are not reassessed to subsidize the rich. Thus, on average, families whose incomes are below $\$ 12,000$ a year must pay $\$$ I 4 I per family in additional taxes to compensate the rich. ${ }^{173}$ Subtracting the tax relief for the rich and adding the tax increase for the poor to the initial city tax columns in Table I gives the new city tax distribution presented in Table VI. ${ }^{174}$ Table VI shows a substantial shift in favor of the upper income classes. The direct tax rates against income needed to finance the common $\$ \mathrm{r}, 300$ budget falls from slightly above 0.06 for the rich to 0.05 , while the rates for the two lower income classes rise from about 0.07 directly after the Hawkins principle is mandated to the 0.08-0.I I range following adjustments in city assessments. Because of these tax

${ }^{173}$ This extra tax is allocated across the two lower income groups in proportion to the share of the tax base "owned" by them. The very poor must pay \$150 per family more in taxes while the lower middle class must pay $\$ 136$ per family more. The somewhat counterintuitive conclusion that the poor pay more than the relatively wealthier lower middle class results from the assumption of higher assessment rates on low income property.

${ }^{174}$ New net fiscal costs for city residents will therefore be their new direct tax cost minus their original land premium (Table II). It might well be argued that the assessment rate changes needed to redistribute the tax burdens would prompt changes in land values within the city. We believe that these effects would be small, especially since the tax changes compensate for expenditure changes. See Wales \& Weins, supra note 46; Edel \& Sclar, Taxes, Spending, and Property Values: Supply Adjustment in a Tiebout-Oates Model, 82 J. Por. Econ. 94I (I974). For the rental market, our assumption of no land value change holds as long as a substantial portion of the tax increase is passed on to renters in the form of higher rents. See generally Orr, The Incidence of Differential Property Taxes on Urban Housing, 2I NAT'x TAX J. 253 (I968). 
changes within the city, no major exodus of city families to the suburbs is likely to occur. The suburban distribution of taxation is therefore unaffected. The within-city tax inequalities are strong enough, however, to still have a substantial effect on region-wide tax performance. The regional measure of tax regressivity, $\epsilon$, rises from the pre-reform values of 1.054 for direct tax costs and 1.027 for net fiscal costs to $I .07$ I and 1.043 respectively after the city officials have been allowed to react to the Hawkins mandate (Table VI, columns 2, 3).

Of course, the exact changes resulting from a reaction to the Hawkins approach are difficult to predict, but the move towards increased tax regressivity is clear enough in any region where the wealthy residents are mobile. While the gains resulting from increased equity on the expenditures side as described in Table 3 remain, they are counterbalanced by a decline in tax equality.

An analogous response from city officials is likely to occur if the city is forced to follow only the Hellerstein equal assessment mandate. Again, the primary effect of the judicial requirement will be felt within the central city since it is there where the problems of inequitable assessment practices are most severe. Just as before, city officials can be expected to adopt a new fiscal strategy to protect the tax base threatened by the mobility of the wealthy. But now, instead of suffering a decrease of service expenditures as under Hawkins, upper income classes lose on the tax side as their assessments are increased relative to the status quo. Comparing the distribution of tax dollars in the pre- and post-Hellerstein regimes shows that the city's direct tax rates rise from 0.062 to 0.065 for the wealthiest group and from 0.064 to 0.065 for the upper middle class. City officials who wish to compensate the rich for these tax increases can alter the distribution of expenditures to favor the wealthy. The analogy is now complete; under a Hawkins mandate, the city creates assessment disparities to compensate, while in a Hellerstein approach, the city uses expenditure differences to alleviate the "penalty" on the rich.

We shall assume city officials increase public expenditures for upper income families to match exactly these families' Hellersteinimposed tax increases. In our typical metropolis, the results show that the upper income residents within the central city will enjoy a $\$ 169$ per family increase in expenditures $(\$ 2,190-\$ 2,02 \mathrm{I})$, while the upper middle class benefits by a $\$ 39$ per family $(\$ I, 957-I, 9 I 8)$ addition. ${ }^{175}$ The anti-equalizing effect of this spending realloca-

${ }^{175}$ All other income groups also show a slight rise in spending (roughly $\$ 30$ to $\$ 40$ per family). The reason is that the majority-rule voter with the median income enjoys a small net reduction in the tax costs of public services with 
tion is measured by the recalculated value for the spending equality statistic $a$. Within the city, $a$ rises from 0.25 before reform to 0.27 after reform, indicating a fall in spending equity (Table $\mathrm{V}$, column 2). Once again, the suburban spending distribution is unaltered since there will be no movement of families within the region following the central city's fiscal adjustment. But the regional spending distribution is now less equitable due to the decline in equity within the city. For the overall region, $a$ rises from 0.35 to 0.36 (Table V, column 2).

Again, the actual changes following reform need not exactly match those found in Table V. What is important is the potential for a substantial anti-equalizing trend in city spending as a realistic consequence of the Hellerstein approach. To be sure, the benefits on the tax equity side are important, but they are achieved at the cost of increased spending inequality. ${ }^{170}$

equity-based reassessments. For this decisive voter, the tax advantages from assessment equity outweigh slightly the less favorable service distribution following the city's efforts to keep its rich.

This increase, however, is distributed disproportionately towards the rich. The reassessment needed for tax equity lowers the median income family's tax price by about $5 \%$ which, given the price elasticity of demand for city services of -0.6 , implies a $3 \%$ rise in all public sector spending. The new city spending pattern before any reallocations across income classes is given in column 2 below while column 3 gives the new, post-reassessment tax pattern needed to support that spending level. Column 4 reports the new dollar surpluses ( $=$ expenditure less tax). These post-reform surpluses are to be compared to the pre-reform surpluses reported in column 7 . Note the decline for families in the $\$ 25,000$ income bracket.

\begin{tabular}{|c|c|c|c|c|c|c|}
\hline \multirow[b]{2}{*}{$\begin{array}{c}\text { Income } \\
\text { (I) }\end{array}$} & \multicolumn{3}{|c|}{ Post-reform } & \multicolumn{3}{|c|}{ Pre-reform } \\
\hline & $\begin{array}{l}\text { Exp. } \\
\text { (2) }\end{array}$ & $\begin{array}{l}\operatorname{Tax} \\
(3)\end{array}$ & $\begin{array}{c}\text { Surplus } \\
(4)\end{array}$ & $\begin{array}{c}E x p . \\
(5)\end{array}$ & $\begin{array}{l}\operatorname{Tax} \\
(6)\end{array}$ & $\begin{array}{c}\text { Surpluts } \\
(7)\end{array}$ \\
\hline$\$ 5,000$ & $\$ 1,396$ & $\$ 426$ & $\$ 970$ & $\$ 1,356$ & $\$ 499$ & $\$ 857$ \\
\hline 10,000 & $I, 66 I$ & 852 & 809 & $\mathrm{r}, 6 \mathrm{r} 3$ & 899 & 714 \\
\hline 15,000 & $\mathrm{I}, 838$ & $I, 278$ & 558 & $I, 785$ & 1,270 & 515 \\
\hline 20,000 & $I, 975$ & $\mathrm{I}, 704$ & $27 I$ & I,918 & $x, 62 I$ & 297 \\
\hline 25,000 & 2,082 & 2,129 & -47 & $2,02 \mathrm{I}$ & 1,960 & 61 \\
\hline
\end{tabular}

To restore the families with $\$ 25,000$ in income to their old surplus levels, local expenditures for this group must be increased by $\$ 108$ per family. This sum can be raised without increasing local taxes by redistributing services from the lower three income classes (who have enjoyed an initial increase in dollar surpluses) to the upper class. A total of $\$ 10$ per family from those with income less than $\$ 15,000$ will be sufficient to transfer $\$ 108$ per family to those with incomes greater than $\$ 25,000$. We subtract $\$ 10$ per family from expenditure column 2 above for the lower three classes and add \$108 per family to the richest class.

${ }^{178}$ Commercial interests are also the beneficiaries of some of the pre-reform political compromises. Thus, reform may also have an adverse impact on the commercial and industrial base. See, e.g., Holland \& Oldman, Estimating the Impact of Full Value Assessment on Taxes and Values of Real Estate in Boston, in Metropolitan Financing; Principles and Practice (G. Break ed. 1978) (con- 
Obviously, given the flexibility of city officials in circumventing the dictates of either a Hawkins or Hellerstein approach if separately enforced, a combined approach would seem to offer the potential for greater long term gains in both spending and tax equality. Under a dual mandate, city officials have few options left; their two primary tools for maintaining the tax base, changing either the expenditure or tax pattern, are now restricted.

Even within joint enforcement, however, the city is not totally without options. One possible alternative for city officials would be to use special assessments to pay for public services, thus allowing cities to allocate services differentially across income classes. But this strategy may create more serious problems because the widespread use of special assessments effectively denies the city's residents access to the tax base of commercialindustrial property. For the central city rich, the added tax costs incurred are likely to outweigh any cost savings made available from the extensive use of special assessments. A more likely strategy is for the city officials to attempt to turn the provision of distributionally pro-poor public services over to the state or to the private market. Some cities have already adopted this strategy. ${ }^{177}$ While there is a serious threat of "exit" to the private market, an extensive use of this strategy is unlikely for the same reason that made special assessments unattractive - the loss of industrial tax base to support middle and upper class resi-

cluding that the enforcement of the full valuation decision in Massachusetts would raise property taxes on old commercial and industrial property).

Our analysis here has concentrated on the enforcement of assessment equality across residential properties. We have implicitly assumed that commercial property as a class will continue to be assessed at a rate less than that applied to residential property. This assumption is not unreasonable given the trend in many states towards constitutional protection of differing assessments for the various property classes.

Paradoxically, perhaps, assessment equity within the commercial class may have anti-equalizing consequences for residential taxation, thus offsetting in part the gains outlined in Table IV. Cities compete for new commercial establishments by granting favorable initial assessments of commercial property. With required assessment equality, either new firms would be assessed at the level of existing establishments, or commercial property already existing would be given the same break as the newcomers. In either case, the older central cities and suburbs with relatively large concentrations of commercial and industrial property currently assessed at high values will suffer as they compete for new tax base with less developed suburbs who are able to give favorable assessments. Lower income families concentrated within these older suburbs and the central city will therefore see a decline in their share of the region's new commercial tax base. In the long run, residential tax inequities will result as the commercial base is further skewed toward the metropolitan fringe.

${ }^{177}$ Philadelphia, for example, has recently closed its municipal hospital at considerable tax savings. Philadelphia Inquirer, Feb. $x 6$, I976, at $x$, col. $x$. 
dential public services. To the extent that "exit" to the private system is encouraged, however, it will be necessary to limit this option through the development of an appropriate array of "fundamental" services judically deemed to be "public" services that cannot be transferred to the private sector. ${ }^{178}$

Even where "exit" to the private market does not occur, joint enforcement of the Hawkins and Hellerstein mandate still does not guarantee that the region's tax and spending equity will be improved; there still remains the threat posed by family mobility. Suppose the courts have adequately constrained the city's discretion in favoring the rich, thus, in effect, requiring the city to redistribute services and dollars from rich to poor. There is still no guarantee that the rich will remain to be so "exploited." If the costs are too onerous, they will relocate in the suburbs where they will find attractive fiscal packages. If a substantial number of the rich choose to leave, the city faces a potentially precipitous decline in its tax base which, in turn, will increase the oity's tax price of providing public services. The city's poor may well see their taxes rise in order to fund a lowered level of services. As a result of the increased polarization of income classes throughout the metropolis, the region's tax and spending equity may be substantially lessened.

How probable is this outcome? The most likely to move will be those rich and upper middle class families who were just indifferent between city and suburban living before reform. In fact, these families previously "on the fence" will be willing to pay a hypothetical one-time "exit fee" to escape the redistribution now imposed upon them by the court. The size of the "fee" they would be willing to pay is the difference between the yearly fiscal "savings" associated with relocating (capitalized at an appropriate discount rate) minus moving fees and the brokerage costs of selling one's home. We estimate this exit "fee" a family would be willing to pay to be about $\$$ rooo per family, increasing to $\$ 4000$ per family for those families who avoid the usual brokerage costs associated with relocating. ${ }^{178}$

\footnotetext{
${ }^{178}$ See pp. I699-700 supra.

${ }^{179}$ To calculate this "exit fee" for the marginal family initially "on the fence," we must compare the value to the family of staying in the city with the value of moving to the suburbs. Each residential location, city or suburb, offers the family a different mix of public service expenditures $(G)$, after-tax and aftercommuting income $(y)$, land area $(l)$, and amenities $(a)$. We assume that all families can buy identical housing structures at equal unit prices in all locations. The family derives utility from living in either of the two locations equal to the index $U_{c}=U\left(G_{e}, y_{c}, l_{c}, a_{c}\right)$ for the city and $U s=U\left(G_{s}, y_{s}, l_{s}, a_{s}\right)$ for the suburbs. The city is preferred if $\left(U_{0}-U_{s}\right)>0$ while the suburb will be preferred if $\left(U_{c}-U_{s}\right)<0$. The family is just indifferent-"on the fence"-if $\left(U_{0}-\right.$ $\left.U_{s}\right)=0$.
} 
If the effects of the judicial mandate are substantial, even those families with an initially stronger preference for city living may also wish to leave. The actual number who would move fol-

The difference between $U_{c}$ and $U_{s}$ can be approximated by: $U_{c}-U_{s}=$ $V_{0} \Delta G+V_{y} \Delta y+V_{l} \Delta l+V_{a} \Delta a$, where $V_{g}, V_{l}$, and $V_{a}$ are the (assumed constant) marginal values in dollar terms (i.e., what residents would be willing to pay) for an extra unit of public services, income, land, or amenities respectively. Note that the dollar value of a dollar of extra income, $V_{y}$, is unity.

With the joint enforcement of expenditure and tax equity within the city, $G_{c}$ and $y_{c}$ will be reduced for the richest families as local taxes rise and services decline. This will enhance the relative desirability of a move to the suburbs. The city rich will wish to bid for suburban land, with their maximum willingness to pay measured by the dollar value of the relative losses they suffer by remaining in the city.

We began to estimate this maximum willingness to pay (the "exit fee") by first determining the size of $d \theta=V_{i} \Delta l+V_{a} \triangle a$, when fiscal reform is introduced. For our marginal family before reform, we know $\left(U_{c}-U_{s}\right)=0$. Therefore, before reform $d \theta=V_{l} \Delta l+V_{a} \Delta a=-\left(V_{g} \Delta G+\Delta y\right)$. From Table II we know that $\triangle G$ equals $\$ 4$ Ig for the richest family $\left(G_{c}=\$ 2,02 I ; G\right.$ s $=$ $\$ 1,602)$. The difference in pre-reform spendable income $(\Delta y)$ equals the difference in pre-reform city and suburban taxes plus the difference in city and suburban commuting costs. The direct tax difference is $\$ 686$ per family; the rich family pays $\$ 1,956$ for its city services of $\$ 2,02 \pi$, while it would have to pay only $\$ 1,270$ for the suburban service level of $\$ 1,602$. The difference in annual commuting costs is estimated to be $-\$ I, 065$ per family, that is, the suburban family located ten miles from work pays $\$ 1,065$ more per year to commute than does the city family located one mile from work. The net difference in family income before reform is therefore $\$ 379$ ( $=\Delta y=\$ 1,065-\$ 686)$. Finally, we need to estimate $V_{g}$ for rich city residents. This estimate is calculated from the demand schedule, $G=I .5647 I^{0.7} \pi^{-0.6}$, note 32 supra. We can approximate $V_{g}$ as the price $\pi$ (i.e., the value) which consumers will pay to receive a given level of $G$. As $G$ equals $\$ 2,02 I$ per rich family and as $I$ equals $\$ 25,000$, we can solve for $\pi$ $\left(=V_{g}\right)$. We find $V_{g}=0.88$. Using $V_{g}=0.88, \Delta G=\$ 4 \times 9$, and $\Delta y=\$ 379$, we calculate $d \theta=-\$ 748$ per family. The marginal rich families receive a disutility from their land and amenity consumption within the city of $\$ 748$ per year. The fiscal and commuting benefits of city location offer compensation for this disutility.

Spending and assessment equity reduces this compensation by reducing $\Delta G$ and $\Delta y$. With reform, the rich receive $\$ 1,654$ per family in public services which is now only slightly higher in dollars than the rich suburban level of $\$ \mathrm{r}, 602$ per family. To simplify we approximate this small value of $G_{c}-G_{s}=\Delta G \approx 0$. The relative income advantage of city living is also reduced. As city taxes rise with assessment equity, the tax difference between city and suburb grows from $\$ 686$ per family to $\$ 797$ per family; that is, city residents now pay $\$ 797$ per family more taxes for the same level of public services. The annual commuting cost advantages of city living are unchanged. Thus, $\Delta y$ now equals only $\$ 268$ per family $(=\$ 1,065-\$ 797)$. For the once indifferent rich family we see that $\left(U_{0}-U_{s}\right)$ no longer equals zero but now equals $-\$ 480$ per year: $\left(U_{c}-U_{s}\right)=$ $V_{0} \Delta G+\Delta y+d \theta=V_{0}(\approx 0)+\$ 268-\$ 748=-\$ 480$. Some rich families will now pay up to $\$ 480$ per year to escape the center city. Capitalized at an annual interest cost of 0.1 , this is equivalent to a one time payment of $\$ 4,800$. If we net out the costs of selling one's home (about $5 \%$ of home value $=(0.05)(\$ 25,000)$ $(2.5)=\$ 3,125$ ) plus costs of moving (about $\$ 75^{\circ}$ ) we have a maximal net 
lowing joint enforcement must be determined empirically. Professors Bradford and Kelejian studied the effects of changes in net fiscal benefits (expenditures received minus taxes paid) for city residents on the rate of exit to the suburbs. Bradford and Kelejian found that for each ten percent decline in net fiscal benefits to a given income class, there is a five percent decline in the share of that class who reside within the central city. ${ }^{180}$ Court-induced exit can thus be quite substantial. Using the Bradford and Kelejian model, we estimate that following joint enforcement, nearly all of the rich with incomes above $\$ 25,000$ will choose to leave the city, and that about half of the city's upper middle income families will also exit. ${ }^{181}$

Relocation takes place in two steps. First, because of the relatively fixed stock of suburban housing, not all of the upper income families within the city will be able to relocate immediately. For the first few years after reform, it is possible that only a portion of the city's rich will actually find housing in the suburbs. These few available sites arising from the normal rate of turnover in the suburban housing market will go to the highest

willingness to pay to leave the city of about $\$ x, 000$. If families can sell their homes themselves this willingness to pay rises to $\$ 4,000$. The same analysis applies to all lower income classes, too, but this marginal mover from the $\$ 25,000$ income class who loses the most from fiscal redistribution will be the top bidder for suburban land.

${ }^{180}$ See Bradford \& Kelejian, An Econometric Model of the Flight to the Suburbs, 8I J. POL. EcoN. 566 (1973).

181 The table below summarizes the dollar fiscal surpluses before and after joint enforcement. Tax levels were calculated using $\$ \mathbf{I}, 654$ per family as the mean city spending level.

\begin{tabular}{|c|c|c|c|c|c|c|}
\hline \multirow[b]{2}{*}{$\begin{array}{c}\text { Income } \\
(x)\end{array}$} & \multicolumn{3}{|c|}{ Pre-reform } & \multicolumn{3}{|c|}{ Post-reform } \\
\hline & $\begin{array}{l}E x p . \\
(2)\end{array}$ & $\begin{array}{c}\text { Taxes } \\
\text { (3) }\end{array}$ & $\begin{array}{l}\text { Surplus } \\
\text { (4) }\end{array}$ & $\begin{array}{l}\text { Exp. } \\
(5)\end{array}$ & $\begin{array}{c}\text { Taxes } \\
\text { (6) }\end{array}$ & $\begin{array}{c}\text { Surplus } \\
(7)\end{array}$ \\
\hline$\$ 5,000$ & $\$ 1,356$ & $\$ 499$ & $\$ 857$ & $\$ 1,654$ & $\$ 4 I 4$ & $\$ 1,240$ \\
\hline $10, \infty 00$ & $x, 613$ & 899 & 714 & I,654 & 827 & 827 \\
\hline$I_{5}, 000$ & $I, 785$ & $I, 270$ & $5 I_{5}$ & I,654 & 1,240 & 414 \\
\hline 20,000 & I,9I8 & $I, 62 I$ & 297 & I,654 & $I, 654$ & 0 \\
\hline 25,000 & 2,021 & $I, 960$ & $6 r$ & $x, 654$ & 2,067 & $-4 \mathrm{I} 3$ \\
\hline
\end{tabular}

Only the top two income classes suffer a fiscal decline with joint enforcement. Using Bradford and Kelejian's estimate of 0.5 for the elasticity of exit with respect to the fiscal surplus, it is clear that these income classes leave en masse. The more than $200 \%$ decline in the fiscal surplus of the very rich (from $+\$ 6 x$ to $\left.-\$ 4 I_{3}\right)$ is enough to lead to a 100\% exit of the rich from the center city. The roo\% decline in the upper middle class' surplus (from $+\$ 297$ to 0 ) leads to a $50 \%$ decline in their population within the city. The small decline in the middle class' surplus may lead to a slight exit from the central city, but we assume their flow is zero to simplify other calculations. There is also the possibility that a small flow of low income families will come into the city from the suburbs reflecting the gains to those groups. 
bidders. The highest bidders will be those families most eager to escape the city in the post-reform era, specifically those initially "indifferent" city families who would be willing to pay a full $\$ 1,000-\$ 4,000$ "exit fee." This "fee" will accrue to the rich suburban families who leave the region and sell to the relocating city rich. Meanwhile, during this intermediate time horizon, the judicially-imposed tax and spending patterns remain in force, benefiting the city's poor and lower middle class.

In the long run, however, the supply of highly valued suburban housing will increase in response to the greater demand. Through new construction, developers and land speculators will capture a share of the post-reform windfalls, with speculative profits falling to zero as supply grows to meet the new demand. The full force of exit on fiscal allocations throughout the region will then be felt. The longrun adjustments in equity caused by the movement of families will be particularly important on the tax side. Other things being equal, we estimate that following exit the city's tax base will fall by approximately four percent, thus raising the tax costs to the city's remaining residents. To support the "common" \$I,300 per family budget, city tax rates must be increased, and since only lower income classes are left within the city, it is the poor's costs which rise. Post-reform relocation increases the measure of tax regressivity, $\epsilon$, for direct tax costs from I.048 (before the movement of the rich to the suburbs) to I.053, and for net fiscal costs from I.O2I to r.023..$^{182}$

The decrease in the tax base may also have effects on service expenditures since a lower tax base will necessarily raise the tax costs per unit of local services. ${ }^{183}$ The rise in city tax costs will lead to a decline in intracity spending from the $\$ \mathrm{I}, 654$ per family

182 The loss of the $\$ 25,000$ and $\$ 20,000$ families means the loss of their tax base as well. The $\$ 25,000$ families lived in homes valued at $\$ 62,500(=2.5 I)$ while the $\$ 20,000$ families lived in homes valued at $\$ 50,000$. This residential base will not fall completely to zero value but will likely be subdivided into lower value homes and rental space for the poor and middle class. The new equilibrium value of these properties cannot be easily predicted, but we will estimate a 50\% fall in value, which implies roughly a $4 \%$ decline in the city's fiscal base per family $(B)$.

To calculate the direct tax costs when the city tax base per family has declined by $4 \%$ we need only to increase each resident's tax rate by $4 \%$. The city's new, after-relocation tax rate against family income rises from 0.065 to 0.068 . New net fiscal costs for city residents are calculated as new direct tax costs plus city land value changes as reported in Table II. Suburban taxes remain as in Tables I and II. Finally, the city-suburb weights used to calculate the new regional weighted average tax for each income class are unchanged for the lower three income classes and reflect the exit from the city to the suburbs for the two upper income classes.

${ }^{183}$ As tax base per family in the city has declined by $4 \%$, the tax price for remaining city residents rises by about $4 \%$. 
directly following joint enforcement to $\$ \mathrm{I}, 6 \mathrm{I}_{4}$ per family after relocation. Overall, however, the longrun effects on expenditures are small, and the measure of expenditure equity, $a$, will be essentially unchanged from that following joint enforcement. ${ }^{184}$

While the exit of the wealthy from the city following joint enforcement lowers the equity in the distribution of taxes within the region, this relocation may have one beneficial side effect for the city's poor. The reduced demand for central city housing may lead to lower rents for poor families. Further, owners of inner city rental property will suffer capital losses as demand and rents decline. Since the ownership of city rental housing rises with income, ${ }^{185}$ the decline suffered by the landlords will be borne disproportionately by the wealthy. But this added "tax" imposed on the inner city property owners is offset when measuring regional equity by the initial windfall profits earned by suburban homeowners and developers. On balance, these wealth transfers between the rich are likely to neutralize each other, leaving the tax rate adjustments captured in the equilibrium increase in $\epsilon$ as the major regional redistribution following joint enforcement.

In summary, our analysis of the longrun effects of a Hawkins or Hellerstein ruling leads to three conclusions. First, a Hawkins decision, while leading to a substantial improvement in regional spending equity may also result in a longrun reduction in tax equity as cities seek to neutralize the redistributive effects of spending reform through less equitable tax structures. Second, a Hellerstein approach, while leading to a longrun improvement in tax equity may lead to a reduction in service equity as cities adopt less equitable spending patterns. Finally, only the joint enforcement of an equal spending and an equal assessment ruling will lead to an unambiguous longrun improvement in local fiscal equity, though the final net gains may be offset somewhat by the mobility of the rich, which allows them to escape to the suburbs. ${ }^{180}$

${ }^{184}$ A new spending table would show city spending at $\$ \mathrm{r}, 6 \mathrm{r} 4$ per family, with suburban spending at the levels presented in Table V. The city-suburb weights used to calculate the regional weighted spending average for each income class would be unchanged for the lower three income classes and would be 0.18 in the city and 0.82 in the suburbs for the $\$ 20,000$ income class, and zero in the city, r.O in the suburbs for the $\$ 25,000$ income class. The new regional distribution of spending would then be: $\$ 1,135$ per family with an income of $\$ 5,000, \$ 1,136$ per family with an income of $\$ r o, \infty 00, \$ \mathrm{r}, \mathrm{r} 93$ per family with an income of $\$ 15,000, \$ 1,357$ per family with an income of $\$ 20,000$, and $\$ 1,602$ per family with an income of $\$ 25,000$. The $\alpha$ value for this distribution is 0.209 .

${ }^{185}$ See generally G. Sterndieb \& R. Burchell, Resmential Abandonment: The Tenement Landiond Revisited (I973); G. Sterniteb, The Tenement LandLORD (I I666).

${ }^{188} \mathrm{~A}$ combined Hawkins-Hellerstein mandate may result in less equity than in the status quo under certain extreme situations. If the rich constitute a major 


\section{B. Fiscal Equity and Tax Base Equalization: Serrano ${ }^{187}$}

As shown above, ${ }^{188}$ the Serrano requirement of tax base equalization, effected by district power equalization, may have a substantial short term impact on tax and spending equity in the regional economy. Our inquiry cannot stop here, however, because longrun adjustments in the private sector of the regional economy are sure to follow. Whether the equity gains will hold following these adjustments remains to be seen. Our work suggests that they will not, at least not in their entirety.

Tax base equality leads to two significant longrun effects which impact upon the fiscal decisions of rich and poor communities alike: land values adjust and housing stocks change. Prior to a Serrano-type reform, one of the attractive features of suburban living for which wealthy families are willing to pay a significant premium is the relatively large tax base per resident. With tax base equalization, these advantages are lost. Our analysis shows that these losses can lead to sizeable adjustments in residential land values. Specifically, land values will fall in the formerly high tax base communities and rise in those with formerly low tax bases. ${ }^{189}$ Land values which once largely reflected fiscal advantages will now measure only location-to-work advantages and the value of other amenities. In addition the consumption of housing services (and therefore the aggregate stock of housing) may also shift. In formerly high tax base communities, the fall to a new effective tax base $\left(B^{*}\right)$ will mean an increase in the local

portion of the city's population, then their exit may stimulate a much larger decline in the mean city $\operatorname{tax}$ base $(B)$ than described above. A large fall in $B$ may reduce the relative attractiveness of the city for the middle class, who will then be encouraged to exit to the suburbs as well. The dynamics may continue until only the very poor remain in the city. In this instance, the equity measures may rise refiecting the absolute decay of the central city. See generally Oates, Howrey \& Baumol, The Analysis of Public Policy in Dynamic Urban Models, 79 J. Por. Econ. I42 ( $19 i \mathrm{I}$ ). This scenario of total decay does not seem likely in areas where the rich are already concentrated in the suburbs, but may be more applicable to newer metropolitan areas where the rich form a large share of the central city's population and the response to the Hawkins-Hellerstein mandate would represent the first movement into certain suburbs.

${ }^{187}$ This Section is based upon work reported in greater detail in Inman, supra note 165 , and Inman, supra note 22.

${ }^{188}$ See pp. r712-21 supra.

${ }^{189}$ According to our model, the value of a typical 0.6 -acre plot in the $\$ 25,000$ suburbs is predicted to fall from $\$ 12,500$ to $\$ 5,460$, a decline of more than $50 \%$. The 0.4-acre plots in the $\$ 20,000$ suburbs fall in value from $\$ 10,000$ to $\$ 7,740$. Central city residents and families in the poor $(\$ 5,000)$, lower middle $(\$ 10,000)$, and middle class $(\$ 15,00)$ suburbs all experience a rise in the value of their property, also by as much as $50 \%$. The new land prices correspond to those which obtain under metropolitan financing of local services. See note 45 supra. 
taxes needed to finance any chosen level of local spending in these communities. ${ }^{190}$ As property taxes are an important determinant of the demand for housing, ${ }^{101}$ housing consumption will decline. Conversely, in formerly low tax base communities, the higher guaranteed tax base $\left(B^{*}\right)$ will cause tax rates to fall and the consumption of housing to rise.

The joint consequence of the changes in the price of land and housing consumption is to change the actual value of each family's taxable property base. Families in the wealthy suburbs whose land has declined in value and who now buy less housing will see their family taxable base decline from $b_{\mathrm{R}}{ }^{0}$ to, say $b_{\mathrm{R}}{ }^{\mathrm{c}}$ $\left(b_{\mathrm{R}}{ }^{\mathrm{o}}>b_{\mathrm{R}}{ }^{\mathrm{e}}\right)$; families in the poorer suburbs and the central city, with more valuable land and housing, see their individual taxable bases increase from $b_{\mathrm{P}}{ }^{0}$ to a new $b_{\mathrm{P}}{ }^{\mathrm{e}}\left(b_{\mathrm{P}}{ }^{0}<b_{\mathrm{P}}{ }^{\mathrm{e}}\right)$. Stated another way, for the wealthy districts, tax base equalization drives individual property values downward because of declines in land values and in the amounts of housing services consumed, while the reverse trend occurs in the poorer areas. These adjustments will be greatest in those communities undergoing the greatest change in local tax base, i.e., the initially very rich and very poor suburbs. ${ }^{192}$

${ }^{190}$ An example will make this clear. If the pre-Serrano tax base is $\$ 100,000$ per family and the desired level of spending is $\$ 2,000$ per family, a $2 \%$ tax is sufficient. Under DPE, however, with a guaranteed tax base $\left(B^{*}\right)$ of, say, $\$ 50, \infty 00$, to spend the $\$ 2,000$ the community will now have to levy a tax of $4 \%$. Moreover, while $\$ 2,000$ in revenues was generated previously, the community's total tax bill is now $\$ 4,000$. The state will keep the difference between the $\$ 4,000$ raised locally and the $\$ 2,000$ of local spending.

191 Estimates of the sensitivity of housing investment to changes in local tax rates can be obtained from studies of housing demand. The annual price including tax cost of a unit of housing services is $p_{I I}=p(i+r)$, where $p$ is the per unit cost of the structure itself, $i$ is the mortgage interest rate, and $r$ is the effective local tax rate. The elasticity of housing stocks with respect to $p_{I I}$ has generally been estimated at $-x$. That is, a 10\% rise in $p_{H}$ leads to a ro\% fall in housing consumption. See Muth, The Demand for Non-Farm Housing, in The Demand For Durable Goods (A. Harberger ed. Ig60) ; Polinsky, The Demand for Housing: A Study in Specification and Grouping, 45 EconomeTrica 447 (1977).

It should be noted that while the changes in land values will follow quite rapidly upon the introduction of Serrano reforms, due to the sophistication and sensitivity of the real estate market, housing stock adjustments will occur much more slowly. They have been estimated to take five to ten years to reach equilibrium. See Muth, supra; Lee, The Stock Demand Elasticities of NonFarm Housing, 46 Rev. EcoN. \& Statistics 82 (I964); Hanushek and Quigley, The Dynamics of the Housing Market: A Stock Adjustment Model of Housing Consumption, 6 J. URB. ECoN. go (I979).

${ }^{102}$ For residents in cities with pre-reform tax bases $(B)$ at, or very near, the selected target base $\left(B^{*}\right)$ we will observe some changes in the families' own tax bases $\left(b^{\prime} s\right)$, but the changes are likely to be small. For example, with $B^{*}$ equal to $\$ 55, \infty 00$ per family, residents in the middle class suburbs and in the central city 
The changes in family tax bases, however, will undo a substantial share of the gains in spending and tax equity promised by a Serrano ruling. The drop in family tax base in the wealthy districts makes local services relatively less expensive under a DPE scheme, thus encouraging local spending; similarly, local services will become more expensive for the once poor districts, decreasing spending. These antiequalizing spending tendencies are also accompanied by a reversal of the gains in local tax progressivity since, ceteris paribus, a higher family tax base means a higher tax bill per family. Hence in the wealthier districts with declining property values, families will have a lower tax bill, while in the poorer districts, tax bills will rise.

More precisely, in the poor districts, the effect of larger family tax bases (increasing from $b_{\mathrm{P}}{ }^{\circ}$ to $b_{\mathrm{P}}{ }^{\mathrm{e}}$ ) is to increase the individual tax price needed to finance local services; from immediate, postreform values of $\pi^{*}\left(=b_{\mathrm{P}}{ }^{\circ} / B^{*}\right)$ to equilibrium values of $\pi_{\mathrm{e}}{ }^{*}$ $\left(=b_{\mathrm{R}}{ }^{\mathrm{e}} / B^{*}\right) \cdot{ }^{193}$ This equilibrium increase in local tax price leads to an equilibrium decline in local spending from the initial postSerrano levels reported in Table III. The converse antiequalizing trends in local spending occur in the wealthy districts as local tax prices fall with the decline in family tax bases (from $\pi^{*}=b_{\mathrm{R}} / B^{*}$ to $\left.\pi_{\mathrm{e}}{ }^{*}=b_{\mathrm{R}} \mathrm{e} / B^{*}\right)$. The net effect is to push local spending in these communities back towards pre-Serrano levels.

Table $V$ reports the final, equilibrium distribution of spending where the equalized base $B^{*}$ is set by the state at $\$ 55,000$ per family. Comparing Table V, column 3 to the immediate postreform spending distribution in Table III, column 4 reveals that the equilibrium adjustment process can be significantly antiequalizing. Our measure of regional spending equity $(a)$ rises from Serrano's promised level of 0.125 to the less equitable equilibrium level of 0.2 . Adjustments within the local economy thus cut potential gains in spending equity almost in half.

(where the market value of tax base equals $\$ 58,000$ per family) may experience a small fall in the value of their property as some residents leave for the few high amenity, but initially low tax base, suburban communities. This small fall in land values will lower the families' own tax bases implying a fall in family tax payments $(=r b)$. A fraction of the resulting increase in family after-tax income will be spent on improved housing. This increase in housing structures generally offsets the fall in land values so that in the long run family tax bases remain close to their immediate post-reform levels. The same economic forces are at work, but for residents in communities with tax bases initially near $B^{*}$ the impact of these pressures will be slight.

${ }^{193}$ This is not strictly correct. In an economy with variable assessments of properties, $\pi^{*}$ will equal $(M V B / B)\left(b / B^{*}\right)$. For our average metropolitan economy this distinction is not quantitatively important so we omit it from our discussion. All of our calculations of new spending levels, however, do use the technically correct definition of $\pi *$. 
Similarly, the equilibrium changes in family tax bases seriously affect the gains in taxpayer equity. The pre-Serrano disparities in local tax base were the major source of regressivity in the local tax structure; poorer residents in poor tax base communities needed higher property tax rates for a common budget, and hence their tax rates as measured against income were relatively higher too. By equalizing tax bases, the local property tax rates needed to finance a common budget were equalized. Our measure of tax equity $(\epsilon)$ fell to $I .006$ indicating a nearly proportional local tax system. ${ }^{194}$ In the long run, however, the changes in family tax base will counteract these gains as the family tax bill (rate times family base) will change over time in a regressive direction. As we have seen, the taxable base for families in the poorer communities will increase; for the wealthy, it will decrease. A rise in family tax base will increase the tax bill needed to finance the common $\$ \mathrm{r}, 300$ budget. ${ }^{195}$ Assuming, then, that incomes remain constant, these changes in family tax base mean that the poor will pay more for their services, and the wealthy less. The system becomes regressive once again.

Table VI, column 4 shows how serious this longrun trend might be. We find that tax rates against income rise from 0.067 to 0.073 in the poorest suburbs (where the average income is $\$ 5,000$ ) and fall from 0.066 to $0.05^{2}$ in the richest suburbs (where the average income is $\$ 25,000$ ). The central city and the middle class suburbs show no changes, reflecting the stability of their family tax bases when the target base $B^{*}$ is near their community's pre-reform tax base. ${ }^{196}$ The result: our tax equity measure ( $\epsilon$ ) rises from 1.006 (Table IV, column 6) to I.oI3 (Table VI, column 4 ), reducing the initial improvement in tax performance by a third. ${ }^{107}$

It is important to stress, however, that despite these antiequalizing adjustments following the introduction of Serrano reforms, the overall effects on spending and tax equity are favor-

\footnotetext{
${ }^{194}$ The remaining regressivity was due to regressive assessment variations within the central city. See pp. I7I2-2I supra.

${ }^{105}$ Assume, for example, that the district wishes to spend $\$ 2,000$ and the guaranteed tax base is $\$ 50,000$. The tax rate would then be set at $4 \%$. If the actual tax base of the family increases from $\$ 30,000$ to $\$ 40,000$, the family's tax bill rises from $\$ 1,200$ to $\$ 1,600$.

${ }^{108} \mathrm{See}$ note $\mathrm{I92}$ supra.

${ }^{197}$ The tax rate against income is defined as $r b / I$, where $I$ is the income for each class of families. The equilibrium ratios of base to income $\left(b_{e} / I\right)$ for the five suburban income groups are 2.76 for $\$ 5,000$ families, 2.58 for $\$ 10,000$ families, 2.5 for $\$ 15,000$ families, 2.08 for $\$ 20,000$ families, and $x .97$ for $\$ 25,000$ families. The equilibrium residential tax rate $(r)$ needed to finance the $\$ I, 300$ per family budget is 0.0267 when $B^{*}$ equals $\$ 55,000$ per family. Multiplying $r$ times $\left(b_{e} / I\right)$ defines each family's equilibrium tax rate against income.
} 
able. The longrun net gains in equality still show a fall in $a$ from 0.35 to $0.2 \mathrm{I}$ and a fall in $\epsilon$ from 1.027 to I.013. Moreover, while the windfall redistribution in land values towards the poor and lower middle class does entail some diminution of equity gains, it also represents an equalizing transfer of wealth. Serrano is not a panacea, but it is a substantial move in the direction of improved fiscal equity. ${ }^{198}$

\section{Fiscal Equity and Suburban Access}

The significant equity gains potentially possible under a $M t$. Laurel reform depend on whether the suburban and central city poor in fact relocate in the wealthy suburbs. There are two questions. First, will housing for the poor be built on the land opened by $M t$. Laurel? The answer to this question would seem to be yes. Absent cost-generating local housing regulation, the technology is now available to build reasonably priced, low to moderate income housing. ${ }^{199}$ Low income housing can also be developed by subdividing the existing housing stock into smaller units if local building codes permit. In any case, the crucial question on the supply side is whether builders will construct such housing. One potential problem arises if housing codes, even if not overly restrictive, vary radically from community to community. Firms planning to build low cost housing may have to invest significant resources in legal fees and local bargaining to build homes on a technically efficient scale. While these additional costs imposed by local housing codes may be significant, ${ }^{200}$ on balance

${ }^{198} \mathrm{~A}$ final comment on the equilibrium effect of base equalization is in order, for it illustrates the complexities of implementing fiscal reform. The adjustments described above all require market-induced changes in suburban and city property values to be reflected in changes in tax base. For this to occur, property values must be reassessed as market values change. If they are not, our tax bases $(b$ and $B)$ will not change, and the equilibrium adjustments described above will not occur. Hence the earlier impact effects of tax base equality described in Part III ( $a=0.125, \epsilon=1.006$ ) would hold in their entirety. Inman, supra note I87, has estimated the reassessment lag for New York state - often reported as one of the slowest - to average about 5 to 8 years. Paradoxically, a Hellerstein decision to improve the local assessment procedures will thus quicken the postSerrano, antiequalizing adjustment process.

${ }^{100}$ Current estimates place the cost per square foot of new housing at $\$ 20$. See National Association of Home Builders, Component Cost Data (Jan. I978). To meet the FHA minimum square footage requirement, new homes must have at least 960 square feet of living space. Therefore, the estimated structural cost per new dwelling unit is approximately $\$ 19,000$. Much of the recent increase in housing price may be attributable to land cost rises caused by local housing policies. See, e.g., S. Seider, Housing Costs \& Government RegulaTTONS (I978).

${ }^{200}$ See generally Markovits, The Distributive Impact, Allocative Efficiency, and Overall Desirability of Ideal Housing Codes: Some Theoretical Clarifications, 89 HARV. L. REV. I8I5 (I976). 
we expect that the large benefits which the poor stand to gain by relocating ${ }^{201}$ will be sufficient to compensate potential builders for such costs and to ensure construction.

The second, and central, question for evaluating the longrun effects of a Mt. Laurel decision is whether or not the poor will in fact relocate in the rich suburbs. The answer is not obvious. While there are clear fiscal advantages to the poor with relocation, there are costs as well. The one-time expenses of selling one's home and actually moving, together with the added annual expenses of commuting to work from a distant suburb, may be substantial. Offsetting the added costs are the potential savings offered by reductions in the annual cost of housing plus any benefits associated with the social amenities present in the rich suburbs. In order to quantify the net family savings from relocation, it is first necessary to specify the means of judicial enforcement utilized. We have assumed that as an outer bound, the effect of the court's decision in the $M t$. Laurel reforms will be to divide the suburban housing market into two distinct markets, one for the poor and another for all other income classes. Suburban land values in the court-protected, low income housing market will then reflect only the poor's demand for each location. Since the poor bid less than the rich for any location, land costs will fall from their original levels in these protected subdivisions of the rich suburbs. This decline in land costs represents one component of the fiscal benefit to the poor - a saving in housing expenses. $^{202}$

To predict relocation patterns we must determine the overall net gains for the poor of moving from their present residences to each of the four upper income $(\$ 10,000-\$ 25,000)$ suburbs. The net gains represent the annual value to the family of the new fiscal package plus the value of the lower housing costs minus the sum of the amortized cost of moving and the added cost of commuting. The fiscal advantages to the suburban poor of relocating in the richest suburb, for example, have been estimated earlier at \$5 Io per year per family. ${ }^{203}$ Extra commuting costs would be about $\$ 578$ per year, using $7 \%$ per mile as the direct travel costs of the extra miles travelled and $\$$ r.oo per hour as the value of

${ }^{201}$ See note 205 infra.

202 Before Mt. Laurel, the suburban poor occupied land worth $\$ 47,2 \mathrm{I}_{4}$ per acre, see note 45 supra, and they bought 0.0529 acres at an annual rental or mortgage cost of $\$ 250\left(=\left(\$ 47,2 x_{4}\right)(0.0529)(. I)\right.$, where the interest rate is ro\%). The central city poor occupied 0.0529 acres worth $\$ 49,609$ per acre and paid an annual land cost of $\$ 262$. Following MLt. Laurel, the same acreage can be occupied in the suburbs for roughly $I / 3$ this price. See note 206 infra.

${ }^{203} \mathrm{See}$ note 50 supra. 
time involved in the added commute for a lower income family. ${ }^{204}$ The moving expenses are estimated to be $\$ 85^{\circ}$, which when amortized at 10\% per year equals an annual cost of $\$ 85$ per year. Thus, the fiscal gains from relocation are offset by commuting and moving costs. Savings in housing costs may tip the balance. Our calculations show that the land value savings available to the suburban poor from moving to the richest suburbs total $\$ 200$ per year. ${ }^{205}$ With this added benefit, the net gain per family is approximately $\$ 47$ per year $(=\$ 5$ I0 $+\$ 200-\$ 578-\$ 85)$. Having weighed all possible economic costs and benefits, we find the final gain to be positive. Given the likely additional but unconsidered environmental amenities found in rich communities, we conclude that with maximal enforcement of $M t$. Laurel reforms, poor suburban families will desire to relocate in the richest suburb. Further, they will pay at least $\$ 47$ per year, or a single amortized sum of at least $\$ 470$, for the privilege. ${ }^{208}$ Using a similar calculus for the other suburbs and for the central city poor, we find that the suburban poor will wish to relocate in all four upper income suburbs, while the central city poor will find only the $\$$ I5,000 and $\$ 10,000$ suburbs sufficiently attractive. The city poor reject the wealthier fringe suburbs because the added commuting costs outweigh the relatively small fiscal advantages of relocation.

The rich suburbs do, however, have two additional strategies to discourage the entry of the poor. First, by selecting very large levels of local service spending, the rich can impose a high total tax cost upon the poor and thereby discourage their relocation. However, since the rich will have to pay for the high service

${ }^{204}$ See Mohring, The Benefits of Reserved Bus Lanes, Mass Transit Subsidies, and Marginal Cost Pricing in Alleviating Traffic Congestion, in CURRENT Issues IN Urban Economics rgo (P. Mieszkowski \& M. Straszheim eds. 1979).

${ }^{205}$ This gain is estimated as an annual savings of $\left(\$ 47,214\right.$ per acre $\left.-p_{2 n}\right)$ (0.0529 acres) (0.I) where $\$ 47,214$ per acre is the current price of land paid by the suburban poor and $p_{L_{n}}$ is the new price per acre paid by the poor in the richest suburb. This new price will initially equal the opportunity cost of the land in its next best use, that is, the agricultural price of land which we have estimated at $\$ 9,463$, see note 45 supra. Thus, the initial land value savings will equal $(\$ 47,214-\$ 9,463)(0.0529)$ (0.I) or about $\$ 200$ per year.

${ }^{208}$ As there will be about 19 poor families per acre, the price of the "poor only" acre will therefore rise to I9 plots $X \$ 470$ per plot (the capitalized value of $\$ 47$ per year at a Io\% interest rate) above the agricultural price. The equilibrium price of "poor only" land in the $\$ 25,000$ family suburb will therefore be $\$ 9,933+(\$ 470 \times 19)=\$ 18,863$ per acre. The original, pre-Mt. Laurel price of this land was $\$ 21,945$ per acre. The imposition of a "poor only" land market with Mit. Laurel has reduced the value of this suburban land by $\$ 3,082$ per acre. Similar calculations can be made for relocation in the $\$ 20,000, \$ 15,000$, and $\$ 10,000$ income suburbs, where the annual net gain per poor suburban family is estimated to be $\$ 238, \$ 406$, and $\$ 343$ respectively. 
levels as well, there is a trade-off involved. When compared to the option of having the poor and paying for a lower service level or not having the poor and paying for a higher level, the rich will be likely to accept the poor. ${ }^{207}$ Second, the rich suburbs can lower the level of public service provision and contract individually in the private market for many local services. With fewer services provided through taxation, poor families no longer gain a fiscal advantage by relocating. But current federal income tax laws permit the deduction of local property taxes and thus offer a subsidy generally sufficient to exclude this possibility. State and federal grants-in-aid or matching grants for local services also decrease the likelihood of private market exit.

Based on the calculations above for our typical metropolitan area, we find that all of the suburban poor are relocated and that roughly $30 \%$ of the city's poor move as well. Overall, the suburban share of the region's poor increases from the status quo level of $42 \%$ to $59 \%$. After the poor do move, the suburbs may adjust their spending patterns in response to this influx. With the requirement that a portion of the jurisdiction's tax base be turned over to low income housing, the average value of the tax base per family $\left(B_{\mathrm{R}}\right)$ in the richer suburbs will decline. This decline causes the tax price per dollar spending $\left(\pi=b_{n} / B_{R}\right)$ to rise, which in turn lowers the overall demand for public spending on services. The resulting decrease in suburban spending levels coupled with the rise of the average spending level from the pre-Mt. Laurel reform status quo received by the relocated poor gives an additional longrun improvement in spending equity from that observed in Table III. Our measure of regional spending equity $(a)$ has fallen to $0.2 \mathrm{I}$ (Table $\mathrm{V}$, column 4 ). ${ }^{208}$

${ }^{207}$ We estimate that when rich suburban spending reaches the high level of $\$ 4,000$ per family, the poor's net fiscal gain is sufficiently small to discourage their relocation.

${ }^{208}$ The results in Table $\mathrm{V}$ require first recalculating each suburb's equilibrium tax base per family following enforcement of $M t$. Laurel. This is done in two steps: (I) estimate the taxable base per poor family by adding the new value of each poor family's plot of land to a value of a house structure of $\$ 10,000$, and (2) calculate a new weighted average of tax base per family assuming the commercial base and the value of expensive homes within each suburb do not change. Next, redefine the tax prices $(\pi=b / B)$ for the nonpoor in each suburb. As $B$ declines, $\pi$ must rise. As $\pi$ rises, the nonpoor who we assume still control local budgets prefer less spending. The decline in spending is calculated using the price elasticity of -0.6 . The spending level received by the $\$ 5,000$ families in the suburbs is again the weighted average of what each $\$ 5,000$ family receives in their new suburban community. This average is, of course, lower than that reported earlier.

Spending within the central city may change for two reasons, neither of which we suspect is very important. First, as poor families leave the city for the suburbs, the city's mean tax base per family rises, thereby reducing the tax price, $\pi$, for remaining residents. Spending should rise. We have estimated the increase in 
The decline in the tax base per family $(B)$ of the rich suburbs also improves the longrun tax equity performance. The lower average base in the high income suburbs means an increase in taxes for the rich to support the common spending level of $\$ \mathrm{I}, 300$ per family. These extra taxes, in effect, subsidize the services received by the new poor entrants. The regional value of $\epsilon$ falls to I.or3 for direct tax costs, and to I.005 for net fiscal costs (Table VI, columns 5,6$).{ }^{209}$ Thus, unlike the other cases, the maximal equity gains of $M t$. Laurel reform stand up well over the long run and may even show increased equity owing to longrun adjustments in tax base.

\section{Fiscal Equity with Joint Enforcement}

While each thrust of the new local government law promises at least some longrun improvement in local fiscal equity there remains the question what might realistically happen with joint enforcement. The final effects of joint enforcement on tax and spending equity are not simply the sum of the incremental gains in equity offered by the imposition of the individual mandates. Rather than being complementary to each other, the mandates "overlap" in their effects.

This proves to be a particular problem for the two reforms aimed primarily at the suburbs - Serrano and $M t$. Laurel. If Serrano's guarantee of equal fiscal resources is realized, then not much more is gained by moving poor families into rich communities. The $M t$. Laurel equity gains result largely from the ability of the poor to benefit from the favorable tax base conditions in the rich suburbs - a benefit denied to those communities under Serrano. Conversely, in the presence of $M t$. Laurel and its predicted relocation of families, a Serrano ruling is of little benefit. With the poor now spread more evenly over the high and low tax base communities, the average poor family cannot gain by a court order equalizing tax bases.

Serrano or $M t$. Laurel individually produced intrasuburban spending distributions with $\alpha$ values of 0.26 and 0.20 respectively (Table V, columns 3,4). Alone, a Serrano or Mt. Laurel holding will yield an intrasuburban tax distribution for net fiscal costs

tax base per family at no more than $2 \%$. Second, the loss of the poor as a voting bloc to hold down spending and taxes may now also stimulate spending within the city. This effect should be small as well. Thus, we keep city spending at its pre-reform level.

${ }^{200}$ New suburban tax levels follow from our recalculated, lower tax base per family. Direct tax costs rise. Net fiscal costs are calculated as before, except now there are no capitalization advantages in reduced land prices for residents in the $\$ 5,000$ suburbs, since they no longer exist as fiscal units. The central city tax base is not significantly altered so no changes for city residents are required. 
with $\epsilon$ values of I.0I4 and I.006 respectively (Table VI, columns $4,6)$. If enforced jointly, the two cases push the suburban a value to 0.18 and the suburban $\epsilon$ value to $r .006$ (Table V, column 5, and Table VI, column 7). The small improvement in suburban equity which does arise with joint enforcement comes from the fact that some suburban poor still find it advantageous to relocate in higher income suburbs. Of course, given Serrano, the fiscal advantages of relocation are not as sizeable as before. In fact, the only benefit remaining arises from the reduced land prices in exclusionary suburbs caused by $M t$. Laurel's "creation" of a poor-only housing market in those communities. Thus, those poor who relocate in the suburbs further out can buy their current level of housing services at a price lower than before. The lower price is also reflected in a lower family tax base $(b)$, which means lower tax costs than in their more fiscally expensive previous location. Of course, offsetting the fiscal advantage of lower land costs are the added costs of a longer commute plus the onetime charge for the expense of relocating. Using the same methodology as before in computing whether relocation will occur, ${ }^{210}$ we estimate that poor families will relocate only in the \$10,000 and $\$ 15,000$ income suburbs that border their present locations and therefore add little to annual commuting costs. While Mt. Laurel has "opened up" the rich, fringe suburbs, the postSerrano fiscal advantages to the poor of such a relocation are no longer sufficient to compensate for the large additional costs of commuting. Since there is some relocation of city and suburban poor into the less wealthy suburbs, the slightly higher spending level in those communities together with a small additional tax saving results in marginally improved fiscal equity within the suburbs.

In contrast, adding an expanded Hawkins or Hellerstein ruling to either Serrano or Mt. Laurel does improve substantially the region's overall equity performance. The reason for this is straightforward: Hawkins or Hellerstein are both "city" strategies and thus attack a different type of problem than the Mt. Laurel or Serrano "suburb" strategies. The city approach limits the ability of city officials to discriminate among its citizens; the suburban approach ensures a more equitable distribution of the region's fiscal capacities. Even with an effective suburban strategy, the inequities of discriminatory spending or taxing practices within the city remain to be corrected. To calculate any additional gains resulting from Hawkins, we assume that spending within the city is equally distributed across income classes at the city's 
preferred spending level. ${ }^{211}$ With Hellerstein, central city taxes are now assumed to be proportional. ${ }^{212}$ By joining Hazkins and Hellerstein with Mt. Laurel and Serrano, we find that the region's spending distribution is reduced further to an $a$ value of 0.08 (Table V, column 5), while the average tax distribution is lowered to an $\epsilon$ value of $\mathrm{r.002}$ (Table VI, column 7). Though not quite reaching full fiscal neutrality ( $\alpha=0, \epsilon=\mathrm{I} .000$ ), it is clear that joint enforcement is a further step toward improved equality when compared to the most favorable gains available from any single strategy ( $a=0.2 \mathrm{I}$ with Serrano or Mt. Laurel, and $\epsilon=$ I.005 with $M t$. Laurel).

\section{E. An Overview and the Enforcement Issue}

In summary, the urban economy's adjustment to the court's new fiscal rules will undo some of the expected gains, but not all. In Figure 4, we show for each of the four strategies the likely

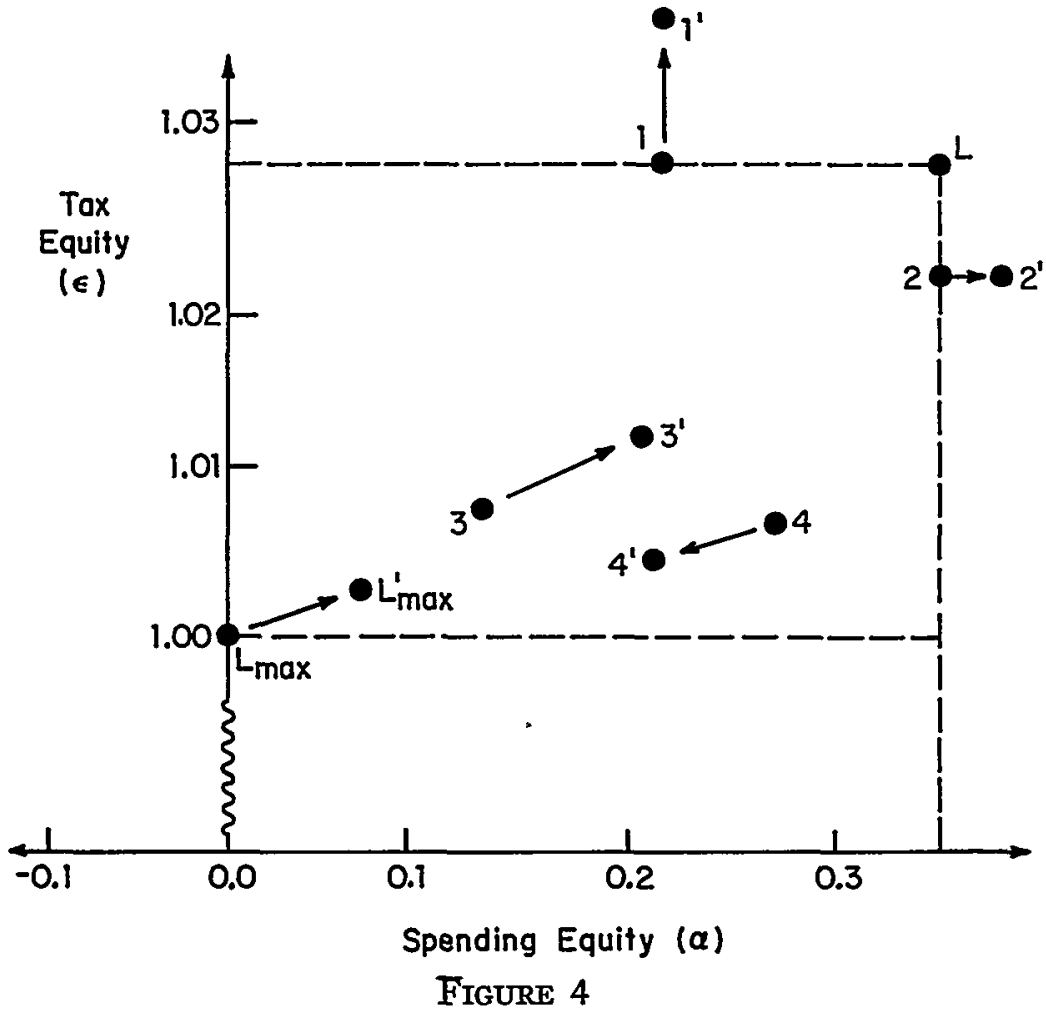

211 With tax base equalization under Serrano, the target base is $\$ 55,000$ per family. This will result in the city selecting a spending level of $\$ 1,576$ per family.

212 The tax rate against family income will equal 0.067 in order to finance the assumed regional budget of $\$ 1,300$ per family. 
equity performance both before and after the urban economy has been allowed to react. The primed points, representing the longrun achievement of the judicial interventions summarize the regional equity results computed above (the original points are reproduced from Figure 3 ). As in Figure $x$, any move towards the origin from the starting point $\mathrm{L}$ along or inside either the spending or taxing axis represents an improvement in local fiscal equity.

For each individual legal strategy, except $M t$. Laurel, the longrun equity achievements fall short of the initial promise of reform. Serrano appears to be the most damaged by longrun adjustments, moving from point 3 to $3^{\prime}$. If Hawkins ( $I$ to $I^{\prime}$ ) or Hellerstein ( 2 to $2^{\prime}$ ) are enforced separately, matters may be worse than before along the dimension of fiscal equity not targeted by the reform. Mt. Laurel enjoys a small improvement in tax and spending equity from the longrun adjustment process ( 4 to $4^{\prime}$ ). Joint enforcement suffers a decline from the promised reform position of fiscal neutrality $\left(\mathrm{L}_{\max }\right.$ to $\left.\mathrm{I}_{\max }{ }^{\prime}\right)$. If point $\mathrm{L}_{\max }$ is accepted as the goal for local fiscal equity, then even a judicial strategy of joint enforcement of all the reforms is likely to fall short of that objective.

This is true not only because of the factors mentioned above. Other antiequalizing pressures may be at work within the urban public economy. First, the joint enforcement of the new judicial mandates within a single metropolitan area may place that region at a longrun competitive disadvantage in the attraction of new commercial property and upper income families. The loss of this tax and employment base to the region as a whole may significantly reduce public services and employment opportunities for middle and lower income families. This would seem to be an especially serious problem for multistate metropolitan regions if only one of the state judicial systems pursues the equity strategies. Second, even if they stay within the region, commercial users and upper income families retain the option of functionally "dropping out" of the public service economy by establishing minimal service enclaves such as those now available in "retirement" communities. While both adjustments stand as potential threats to permanent equity achievements, neither seems a serious danger in the foreseeable future. Sizeable transaction costs preclude a major exodus of firms or widespread restructuring of community fiscal offerings, except perhaps in the very long run. ${ }^{213}$

${ }^{213}$ See note I4 supra. On the potentially serious problem of private market exit with the equalization of local school services, see generally Inman, supra note 165; Sonstelie, Public School Quality and Private School Enrollments, (forthcoming). 
Both of the above limitations do not, therefore, seem as serious as the inherent limitation of our original assumption that the courts will successfully enforce the four reforms. Clearly each new judicial strategy faces potentially serious obstacles to enforcement given that some communities and their residents have a strong economic incentive to subvert the imposition of the new rulings. Courts may well face not only serious challenges from local communities and residents but also limitations resulting from their lack of technical competence in understanding the complex data needed to assess compliance.

Successful enforcement may well depend on legislative enactments, like zoning amendments, or the promulgation of administrative guidelines which the courts can then utilize or monitor. For example, under the Havkins approach, courts attempt to minimize enforcement difficulties by requiring only that dollar input, and not the actual level of services, be equalized. ${ }^{214}$ But even this supposedly simpler task will require sophisticated accounting processes with large data demands. While the methodology is available, ${ }^{215}$ the monitoring expenses may be unacceptable especially since generally there will be no existing administrative agency charged with collecting and organizing such information. ${ }^{216}$

The Hellerstein reform faces similar problems. In order to assess property at full market value, or a constant share thereof, it is necessary to measure the value of each parcel year after year. Again, the methodology is available, ${ }^{217}$ but gathering data for thousands of individual parcels of land will be costly. Since many communities already have well developed assessment procedures, however, equal assessment can probably be enforced by requiring that those procedures be used to produce accurate property values for data banks.

While Hawkins and Hellerstein pose some enforcement difficulties, ensuring the equity performance of a $M t$. Laurel ruling is probably the most difficult. First, our assumption that courts will require the creation of functional quotas for low income housing is a greater extension of the existing case law than the remedies projected for the other reforms. Second, even assuming that

214 See pp. 1696-712 supra.

215 See, e.g., Summers \& Wolfe, supra note 35.

${ }^{216}$ Such outside monitoring of city officials will probably be easiest for observable physical services (sanitation) and for site-specific human services (housing, hospital care, and education). However, dollar equity in police protection, fire protection, and public transportation may be very difficult to check. Since these services constitute a major portion of the city budgets, this problem may prove a severe constraint on the equity gains promised by Hawkins. See generally D. Horowitz, THE CourTs aNd Soctar PoLICY IO6-70 (I977).

${ }^{217}$ See generally J. Dasso, Comproter Applications in Rear Estate (1974). 
courts will adopt this broad remedial goal, the courts may be unable to monitor the long term income of those who qualify for low cost housing. One can imagine a situation in which young middle class families with temporarily low earnings outbid the truly poor by borrowing against their higher future earnings. A problem may also occur at the opposite end of the age spectrum with communities willing to accept a high number of low income elderly who do not demand expensive services such as education. ${ }^{218}$ In effect, Mt. Laurel may open the suburbs not just to the permanent poor who would benefit most from relocation, but also to the young, middle class family in its first years of the earnings cycle or to a disproportionately high number of elderly poor. To protect against this problem, eligibility for low income housing would have to be tailored on the basis of expected permanent or average lifetime income and not on the basis of temporary or current income. While estimates of income based upon earnings projections might be developed, such an exercise places the court in the uncomfortable position of becoming the landlord for the suburbs.

A third major problem with the enforcement of $M t$. Laurel relates to our assumption that all of the rich suburbs have open space sufficient to absorb a "fair share" of the region's poor. While in many developing metropolitan areas this may be true, for denser, more developed regions like the New York area, this is probably not the case. In developed regions, rich communities do have open space, but it presently stands as parks, scattered vacant lots, or large private holdings. Certainly the courts will be hesitant to force conversion of this marginally residential land into sites for low income housing. ${ }^{219}$ At best, transferral will prove to be a tedious, plot-by-plot decision process seriously extending the time horizon for effective enforcement of $M t$. Laurel-type reforms. As the number of available relocation sites declines, the equity gains associated with $M t$. Laurel fall accordingly. Given these three problems of enforcement, our equity projections for the open zoning strategy must be seen as an outer bound likely to be achieved under only the most favorable of circumstances.

${ }^{218}$ Apparently, many suburban communities are increasingly willing to accept high density elderly projects. See, e.g., Taxpayers' Ass'n v. Weymouth Township, 7 N.J. 249, 364 A.2d ror6 (r976), appeal dismissed sub nom. Feldman v. Weymouth Township, 430 U.S. 977 (r977); Maldini v. Ambro, 36 N.Y.2d 48I, 330 N.E.2d 403, 369 N.Y.S.2d 385, appeal dismissed, 423 U.S. 993 (1975).

219 No doubt the difficulty of adapting unusual sites to low income development spurred the decisions in New Jersey exempting "developed communities" from the Mt. Laurel requirements. See generally Pascack Ass'n v. Mayor of Washington, 74 N.J. 470,379 A.2d 6 (r977) (small site in the center of other development would be disruptive of community's character). 
The primary enforcement difficulty with Serrano is not one of administration, but rather one of politics. The reform is not selfexecuting; it depends upon state legislatures to create a process which ensures tax base equality. The DPE aid formula is certainly one option, but it has not fared well before state legislatures. ${ }^{20}$ If state legislatures move at all, they will often do so only incrementally, putting the courts in the difficult position of constantly remanding legislative plans to the state bodies for further adaptations.

A politically more attractive solution than the DPE aid program outlined in Part III is a DPE with a "no recapture" clause. Otherwise identical to the straight DPE, the "no recapture" plan provides that rich communities whose fiscal base exceeds the state mandated target base will no longer be required to contribute revenue directly to the state for financing the aid plan. Thus, the tax and spending levels of residents in the rich communities will be unaffected under "no recapture" DPE. Even though the residents of the poor communities will continue to receive the subsidy needed to ensure the functional target tax base, the lack of contributions from the wealthy areas will result in substantially smaller equity gains than initially predicted. ${ }^{221}$ Previous work on school reform proposals for the New York metropolitan area suggests that in the long run, too, tax and spending equity may be reduced by as much as eighty percent under a "no recapture" DPE. ${ }^{222}$ Thus, only continual judicial pressure for true baseequalizing policies will assure the promised equity gains under a Serrano mandate. ${ }^{223}$

${ }^{220}$ The difficulties faced by the New Jersey Supreme Court in enforcing its mandate provide an apt demonstration of the problem caused by a recalcitrant legislature. The court eventually approved a legislative system that was passed several years after the original order despite the fact that the new law continued large-scale local funding which resulted in interdistrict differentials. Robinson v. Cahill, 69 N.J. 449, 355 A.2d I29 (1976). Even under this plan, the legislature failed to provide the funding needed to alleviate partially the differentials. At this juncture, the court was apparently powerless to do anything. See Robinson v. Cahill, 70 N.J. 155, 355 A.2d I29 (1976). There have been some positive legislative achievements. See Lindquist \& Wise, Developments in Education Litigation: Equal Protection, 5 J.L. \& Educ. I, 22 (1976).

${ }^{221}$ Recapture can be dropped from the aid formula by specifying that no jurisdiction shall be required to pay negative aid; if $M V B>B^{*}$, then $A i d=0$. See p. I 709 supra. The calculations in Tables III and IV were redone using a DPE formula with no recapture with $B^{*}$ again equal to $\$ 55,000$ per family. The regional value of spending equity ' $(a)$ rises from 0.125 with recapture to 0.182 without recapture while the regional value of tax equity $(\epsilon)$ rises from 1.006 with recapture to r.o16 without.

${ }^{222}$ See Inman, supra note 165 , at $1 \times \%$.

${ }^{223}$ Such close monitoring of legislative efforts has in fact occurred in California. See note r24 supra. 


\section{SummaRy AND CONCLUSIONS}

Will the current court-oriented attempts to achieve local fiscal equity be successful? The answer turns on the resolution of three separate issues. First, will the existing judicial precedents, statutory provisions, and constitutional mandates support favorable judicial rulings? Second, if the principles are established, can the judicial mandates be successfully enforced? Finally, if enforced, how far towards the goal of fiscal equity will the courts' doctrines take us?

To be sure, the problems with developing and enforcing economically informed judicial doctrine are great. Present federal law is limited to alleviating racial inequities, while more expansive state reforms are beset with enforcement difficulties. We have placed these first two questions to one side, assuming, often without a strong basis in the existing case law, that the glimmers of reform will grow and be firmly enforced. Our major emphasis has been on answering the third question - what might happen if the new theories were enacted by the courts. In this endeavor, it was necessary to use a host of simplifying assumptions and models. Yet, the process itself, regardless of how stable or precise the resulting numbers may or may not be, is instructive; it allows us to think about the prospects of judicial reform in the broader context of public policy.

Our central conclusion is this: Even the modest redistributive goal of fiscal neutrality - equal service spending and proportional local taxation - is unlikely to be achieved. Part III demonstrated that judicial rulings guaranteeing assessment and spending equity within each city, metropolitan tax base equality, and a more open regional housing market hold the promise of producing short term fiscal neutrality. The analysis of Part IV showed, however, that in the long run and even under the best of circumstances the fiscal performance of the metropolitan economy is likely to remain regressive; the rich will continue to receive more services and to pay proportionately less in taxes than will the poor or middle class.

The reason for the rather modest performance of the interventionist judicial strategy is simple. Despite significant expenditure, tax, assessment, and zoning reforms, a fundamental fact remains: there are still a large number of upper income families who are unconstrained in their decision where to locate and in their ability to purchase differing levels of local public services. Our analysis in Part II listed four conditions underlying urban fiscal inequity: (I) the differences in income between rich and poor families, (2) the freedom of households to locate where they wish and to pur- 
chase local services in their preferred location, (3) tax base disparities among localities, and (4) independent local governments with discretion to discriminate in taxes, services, and access. The current judicial strategies have attacked only two of these four causes - tax base disparities and local government independence. The first two conditions remain untouched by past or proposed judicial rulings. Yet, substantial income differences coupled with the freedom to spend that income as one pleases are the fundamental causes of the observed inequities. ${ }^{24}$ Unless these remaining causes of metropolitan fiscal inequities can be dealt with adequately, no major changes in tax and spending equity are likely to emerge. But programs based on income redistribution or centralized financing of local services will not come easily from state legislatures dominated by rural or suburban interests.

In one sense, then, our analysis has taken us full circle. The current judicial push for increased local fiscal equity was prompted in part by the difficulties of achieving service and tax equity through the legislative process. ${ }^{225}$ When those efforts proved ineffective in extending public resources to the poor, the strategy of judicial reform to alter the rules of local financing seemed an attractive option. But now it seems apparent that this option is also limited, and for essentially the same reason which blocked the legislative route - the key causes of fiscal inequality, income disparities and decentralized financing, are left undisturbed. Whether new political coalitions can be fashioned or persuasive new legal theories devised to achieve fundamental redistribution remains to be seen. ${ }^{226}$ For the advocates of increased local fiscal equity, that is the task ahead.

${ }^{224}$ In contrast, an approach allowing conditions (3) and (4) to stand, but redistributing income or determining services and taxes on a statewide basis could turn the regressive local economy into a progressive one. With equal incomes all residents would have an equal opportunity to obtain the benefit of areas with high tax bases. Cities then would have no reason to discriminate in expenditures, taxes, or access. With centrally determined services and taxes, local tax base disparities would be irrelevant. Thus strategies aimed at conditions (I) and (2) face no immutable economic barriers to achieving progressivity in local services.

${ }^{225}$ See, e.g., Berenson v. Town of New Castle, 38 N.Y.2d IO2, III, 34I N.E.2d $236,243,378$ N.Y.S.2d 672,682 (I975) (since zoning decisions are made locally rather than regionally, courts must assume the "anomalous" position of assessing the reasonableness of local decisions).

${ }^{226}$ The search for novel legal theory has recently concentrated on making certain morality and fairness concepts operative as legal principles. See, e.g., Michelman, In Pursuit of Constitutional Welfare Rights: One View of Rawls' Theory of Justice, I2I U. PA. L. REv. 962 (I973); Richards, Equal Opportunity and School Financing: Towards a Moral Theory of Constitutional Adjudication, 4I U. CHI L. REv. 32 (1973).

One policy which may be both politically acceptable and redistributive in effect is the regional sharing of any future commercial-industrial tax base. Under 
Yet we must emphasize again the importance of other values in controlling the future direction of legal doctrine. There is much to be said for constraining the local government sector even if private decisions override any equity gains attending the control of the public sector. Of course, arguments can also be made that favor a less interventionist position. Strong judicial control of local government financing and land use power risks serious harm to the notion of local control - a value that many respect. ${ }^{227}$ We do not pretend to offer any answers to this debate here. What is important to realize, however, is that judicial decisionmaking must respond not only to debates weighing fairness against freedom. Judicial decisions carry significant economic implications which warrant independent and careful analysis as well.

such a tax sharing program, new industrial base would be taxed at the metropolitan or state level rather than at the local level, with the proceeds of the tax redistributed to local governments directly via grants-in-aid. Since communities cannot be certain that industrial development will come their way, they may prefer an assured share of new development revenues, rather than risk getting no new revenues should development not occur in their locality. The MinneapolisSt. Paul area has recently instituted such a program with initial results indicating a modest yet positive impact on service and tax equity. See Reschovsky \& Knaff, Tax Base Sharing: An Assessment of the Minnesota Experience, 43 J. AM. INST. PLANNERS 36 (I977).

${ }^{227}$ See, e.g., Rose, Confiict Between Regionalism and Home Rule: The Ambivalence of Recent Planning Law Decisions, 3 I Rutcers L. Rev. I (1978). This conflict between local control (home rule) and fiscal equity is one which troubles urban economists as well. Home rule promises an efficient allocation of urban resources, but as we have seen, see pp. 1667-96 supra, lower income houscholds are likely to be seriously disadvantaged in this environment. For how an economist might begin to face this value conflict, see Inman, supra note 165 at I14-rg. 